\title{
HYDROLOGY OF AREA 42, WESTERN REGION, INTERIOR COAL PROVINCE, ARKANSAS
}

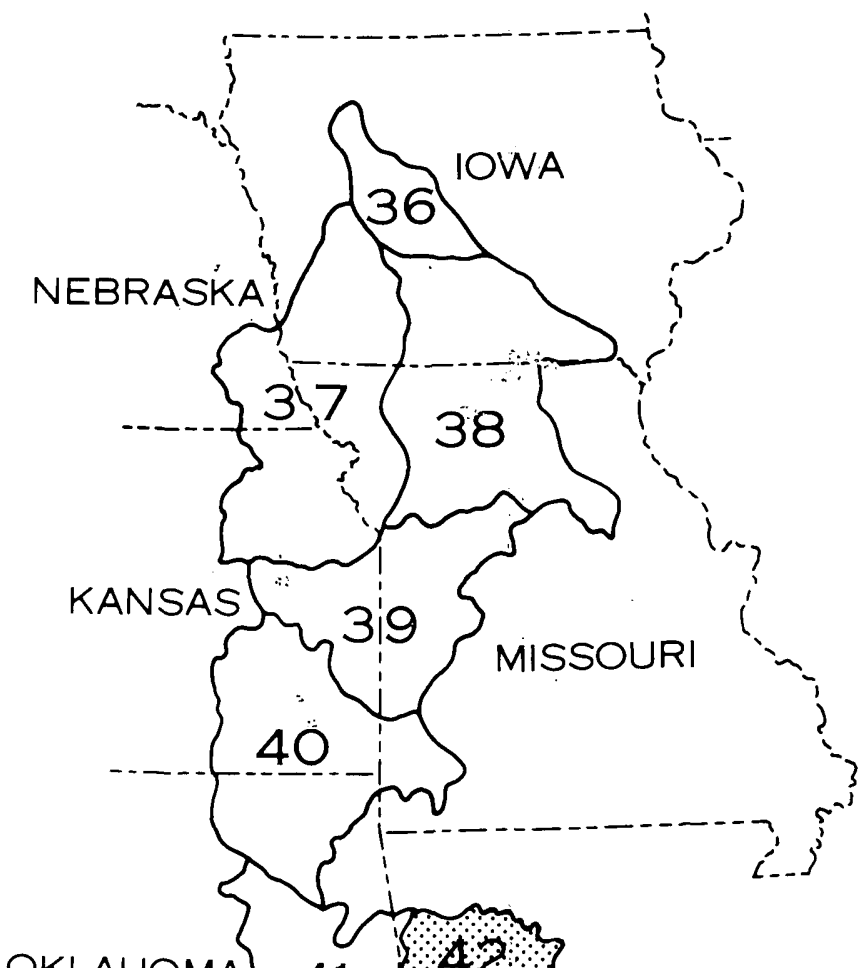

- ARKANSAS RIVER

- ILLINOIS BAYOU

- PETIT JEAN RIVER

- BIG PINEY CREEK

- MULBERRY RIVER

- POINT REMOVE CREEK

OKLAHOMA 41

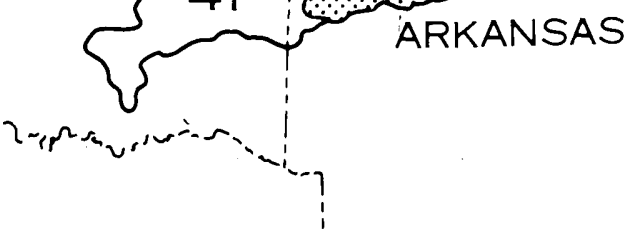

UNITED STATES DEPARTMENT OF THE INTERIOR GEOLOGICAL SURVEY

PREPARED IN COOPERATION WITH THE BUREAU OF LAND MANAGEMENT 
$\because$

$\therefore \because$ 


\section{HYDROLOGY OF AREA 42, WESTERN REGION, INTERIOR COAL PROVINCE, ARKANSAS}

BY

C.T. BRYANT, F.P. LYFORD, K.L. STAFFORD, AND D.M. JOHNSON

U.S. GEOLOGICAL SURVEY

WATER-RESOURCES INVESTIGATIONS

OPEN-FILE REPORT 82-636

PREPARED IN COOPERATION WITH THE BUREAU OF LAND MANAGEMENT 


\title{
UNITED STATES DEPARTMENT OF THE INTERIOR
}

JAMES G. WATT, SECRETARY

\section{GEOLOGICAL SURVEY}

\author{
Dallas L. Peck, Director
}

For additional information write to:

District Chief

U.S. Geological Survey

Water Resources Division

2301 Federal Office Building

Little Rock, Arkansas
Eastern States Office

Bureau of Land Management

350 South Pickett Street

Alexandria, Virginia 


\section{CONTENTS}

Page

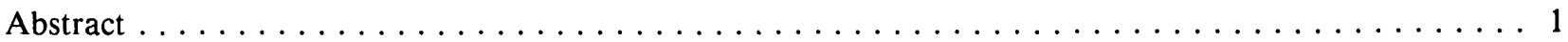

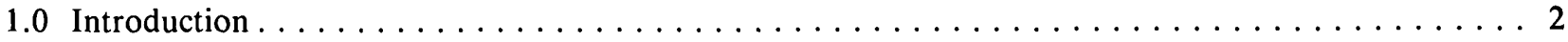

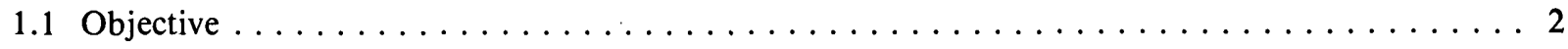

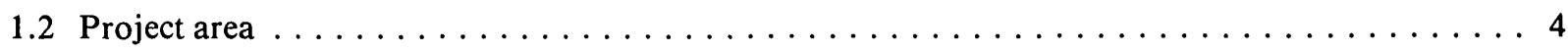

1.3 Coal mining and reclamation $\ldots \ldots \ldots \ldots \ldots \ldots \ldots \ldots \ldots \ldots \ldots \ldots \ldots \ldots \ldots \ldots \ldots \ldots \ldots$

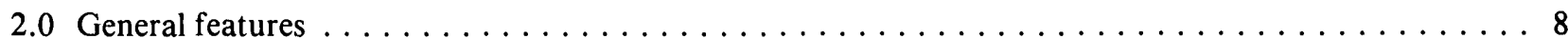

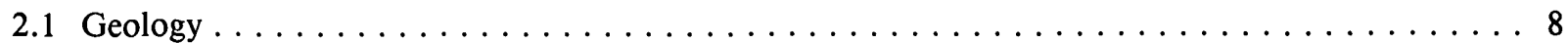

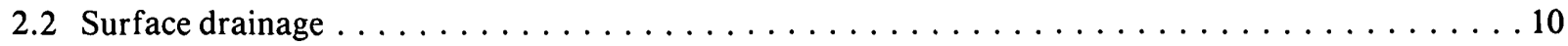

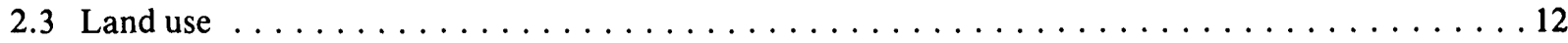

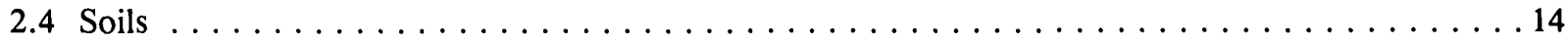

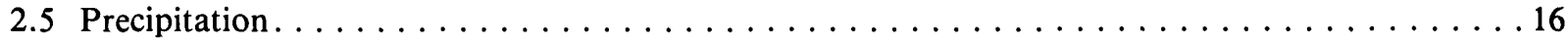

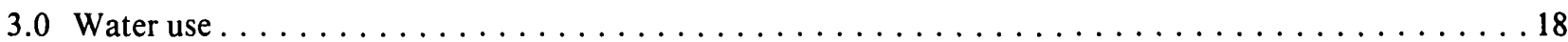

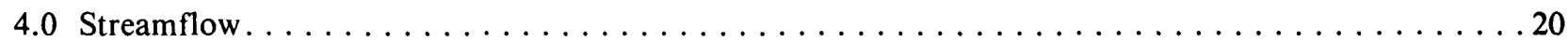

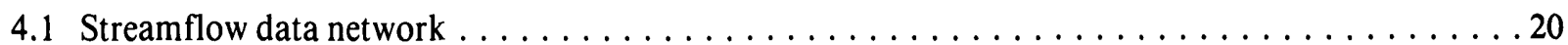

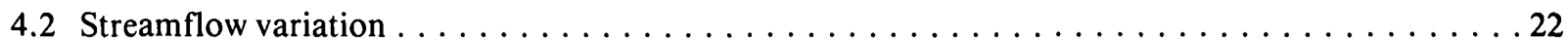

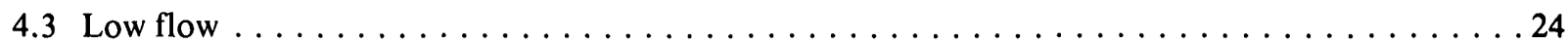

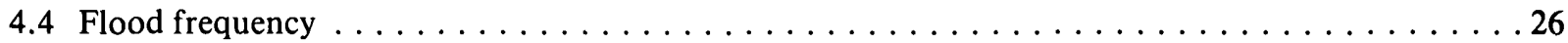

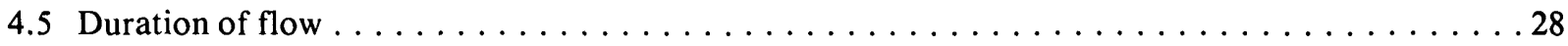

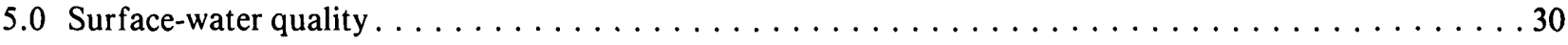

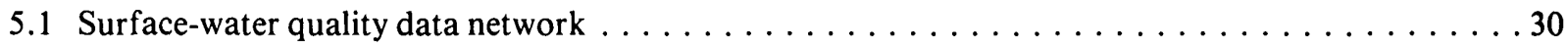

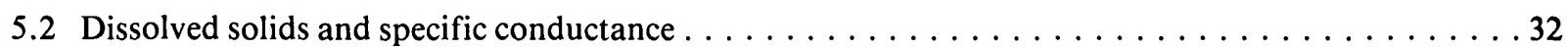

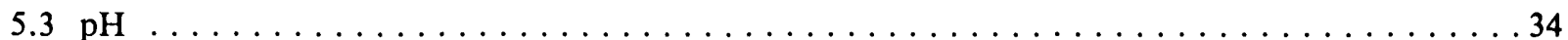

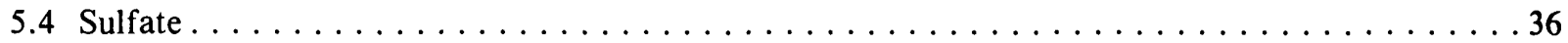

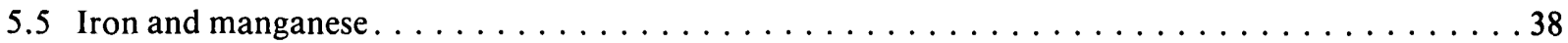

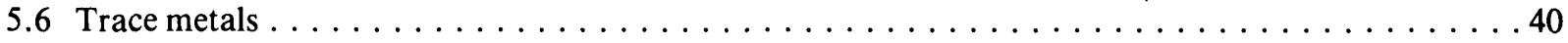

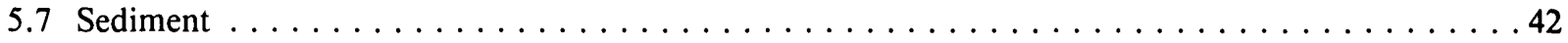

5.8 Sulfate concentrations, specific conductance, and $\mathrm{pH}$ of water

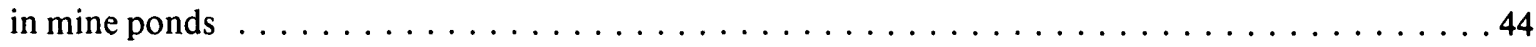

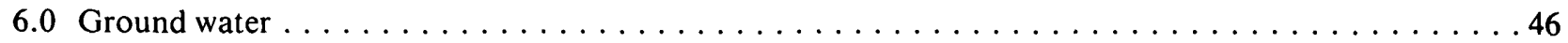

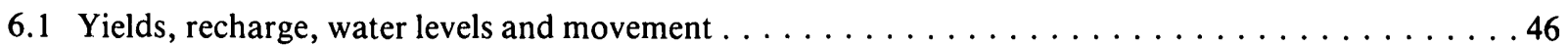

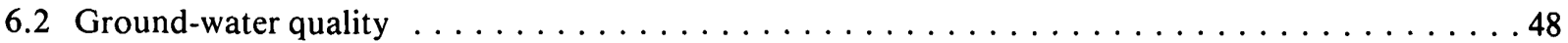




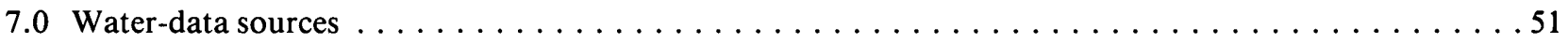

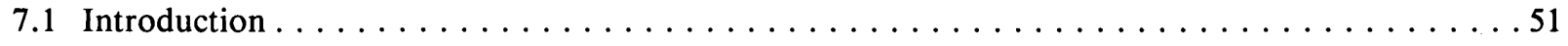

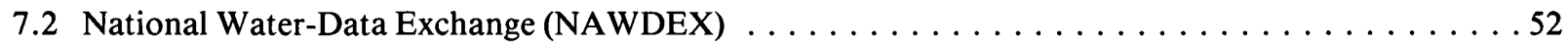

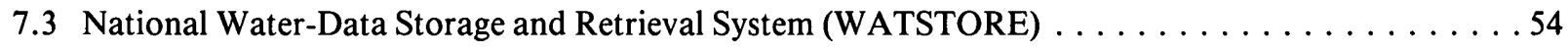

7.4 Index to water-data activities in coal provinces $\ldots \ldots \ldots \ldots \ldots \ldots \ldots \ldots \ldots \ldots \ldots \ldots \ldots \ldots \ldots$

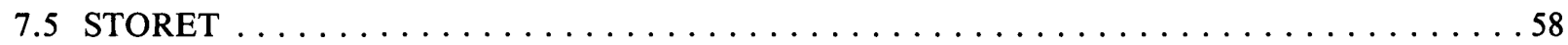

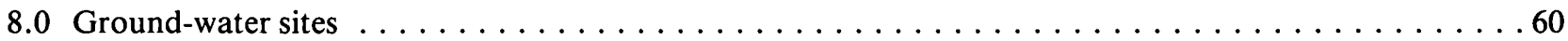

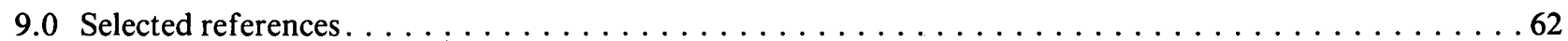




\section{FACTORS FOR CONVERTING INCH-POUND UNITS TO \\ INTERNATIONAL SYSTEM OF UNITS (SI)}

\section{For convenience of readers who may want to use the International System of}

Units (SI), the data may be converted by using the following factors:

\section{Multiply the inch-pound unit}

inches (in)

inches per hour (in/h)

feet (ft)

feet per mile $(\mathrm{ft} / \mathrm{mi})$

miles (mi)

square miles $\left(\mathrm{mi}^{2}\right)$

gallons per minute (gal/min)

million gallons per day (Mgal/d)

cubic feet per second $\left(\mathrm{ft}^{3} / \mathrm{s}\right)$

cubic feet per second per square mile $\left[\left(\mathrm{ft}^{3} / \mathrm{s}\right) / \mathrm{mi}^{2}\right]$

tons per square mile per year $\left[\left(\operatorname{ton} / \mathrm{mi}^{2}\right) / \mathrm{yr}\right]$

short tons

acres

micromhos per centimeter at $25^{\circ}$ Celsius ( $\mu \mathrm{mhos} / \mathrm{cm}$ at $25^{\circ} \mathrm{C}$ )

\section{By}

25.4

25.4

2.54

0.3048

0.1894

1.609

2.590

0.06309

0.04381 3785.

0.02832

0.01093

0.9072

0.405

100

\section{To obtain the SI unit}

millimeters $(\mathrm{mm})$

millimeters per hour $(\mathrm{mm} / \mathrm{h})$

centimeters per hour $(\mathrm{cm} / \mathrm{h})$

meters (m)

meters per kilometer $(\mathrm{m} / \mathrm{km})$

kilometers (km)

square kilometers $\left(\mathrm{km}^{2}\right)$

liters per second $(\mathrm{L} / \mathrm{s})$

cubic meters per second $\left(\mathrm{m}^{3} / \mathrm{s}\right)$

cubic meters per day $\left(\mathrm{m}^{3} / \mathrm{d}\right)$

cubic meters per second $\left(\mathrm{m}^{3} / \mathrm{s}\right) / \mathrm{km}^{2}$

cubic meters per second per square kilometer $\left[\left(\mathrm{m}^{3} / \mathrm{s}\right) / \mathrm{km}^{2}\right]$

metric tons per square kilometer per year $\left[\left(\mathrm{t} / \mathrm{km}^{2}\right) / \mathrm{a}\right]$

metric tons ( $\mathrm{t}$ )

hectares

microsiemens per meter at $25^{\circ}$ Celsius $\left(\mu \mathrm{S} / \mathrm{m}\right.$ at $\left.25^{\circ} \mathrm{C}\right)$

${ }^{\circ} \mathrm{F}=1.8^{\circ} \mathrm{C}+32$ 



\section{HYDROLOGY OF AREA 42, WESTERN REGION, INTERIOR COAL PROVINCE, ARKANSAS}

BY

C.T. BRYANT, F.P. LYFORD, K.L. STAFFORD, AND D.M. JOHNSON

Abstract

\begin{abstract}
The western region of the Interior Coal province is divided into 7 hydrologic reporting areas. The division is based on hydrologic factors, location and size. Each area may comprise one or more hydrologic units (drainage basins). Area 42 is at the southern end of the western region, Interior Coal province. The area is in the Interior Highlands of west-central Arkansas and covers 5,100 square miles. The area is drained by the Arkansas River and its tributaries.

Coal has been mined in west-central Arkansas since 1870 reaching an annual peak production of over 2.6 million short tons in 1907. After almost three decades of general decline, coal mining began increasing in the 1970's. Approximately 665 million short tons of recoverable coal reserves remain. In 1977 and 1979 the State of Arkansas passed legislation to require reclamation of land being strip mined.

Area 42 is underlain mostly by Pennsylvanian rocks with a small outcrop of Mississippian age rocks in the north-central part of the area and with alluvium of the Quaternary System along the Arkansas River. Except for the alluvium, the rocks are folded and faulted. Access to minable coal is a function of the folding and faulting.
\end{abstract}

The principal use of suface water $(28,212$ million gallons per day) is for cooling water for thermoelectric power generation. The second largest use of surface water (34 million gallons per day) is for public supplies. The principal uses of ground water (24 million gallons per day) are for irrigation and rural supplies.

Potential hydrologic problems relating to surface mining are (1) changes in streamflow characteristics, (2) erosion and sedimentation, (3) decline in groundwater levels, and (4) degradation of water quality. Sediment yields tend to increase when vegetation is removed from erosive soils and from surface-mining operations. Decline in ground water levels can occur in and near surface-mining areas when excavation extends below the static water level in the aquifer. This can cause nearby wells and springs to go dry. Acid mine drainage appears to be only a local problem in mined areas, although some trace metal concentrations in tributary streams may have originated in mined areas. Iron and manganese concentrations in water of streams in mined areas are usually within recommended or established limits. Sulfate is usually the major dissolved constituent in water from mined areas and tends to stay dissolved. 


\subsection{INTRODUCTION \\ 1.1 Objective}

\section{Area 42 Report Submitted in Response to Public Law 95-87}

\section{Existing hydrologic conditions and identification of sources of hydrologic information are described.}

\begin{abstract}
A need for hydrologic information and analysis on a scale never before required nationally was recognized when the "Surface Mining Control and Reclamation Act of 1977" was signed into law as Public Law 95-87, August 3, 1977. This report broadly characterizes the hydrology of Area 42 (fig. 1.1-1) in Arkansas, a part of the interior coal province and is one of a series that covers the coal provinces nationwide. The report contains a brief text with an accompanying map, chart, graph, or other illustration for each of a number of waterresources related topics. The summation of the topical discussions provides a description of the hydrology of the area.
\end{abstract}

The hydrologic information presented or availa- ble through sources identified in this report, may be used in describing the hydrology of the "general area" of any proposed mine. Furthermore, it is expected that this hydrologic information will be supplemented by the lease applicant's detailed picture of the hydrology in the vicinity of the mine and the anticipated hydrologic consequences of the mining operation.

The information contained herein should be useful to surface-mine owners, operators, and consulting engineers in the preparation of permit applications and to regulatory authorities in appraising the adequacy of those applications. 


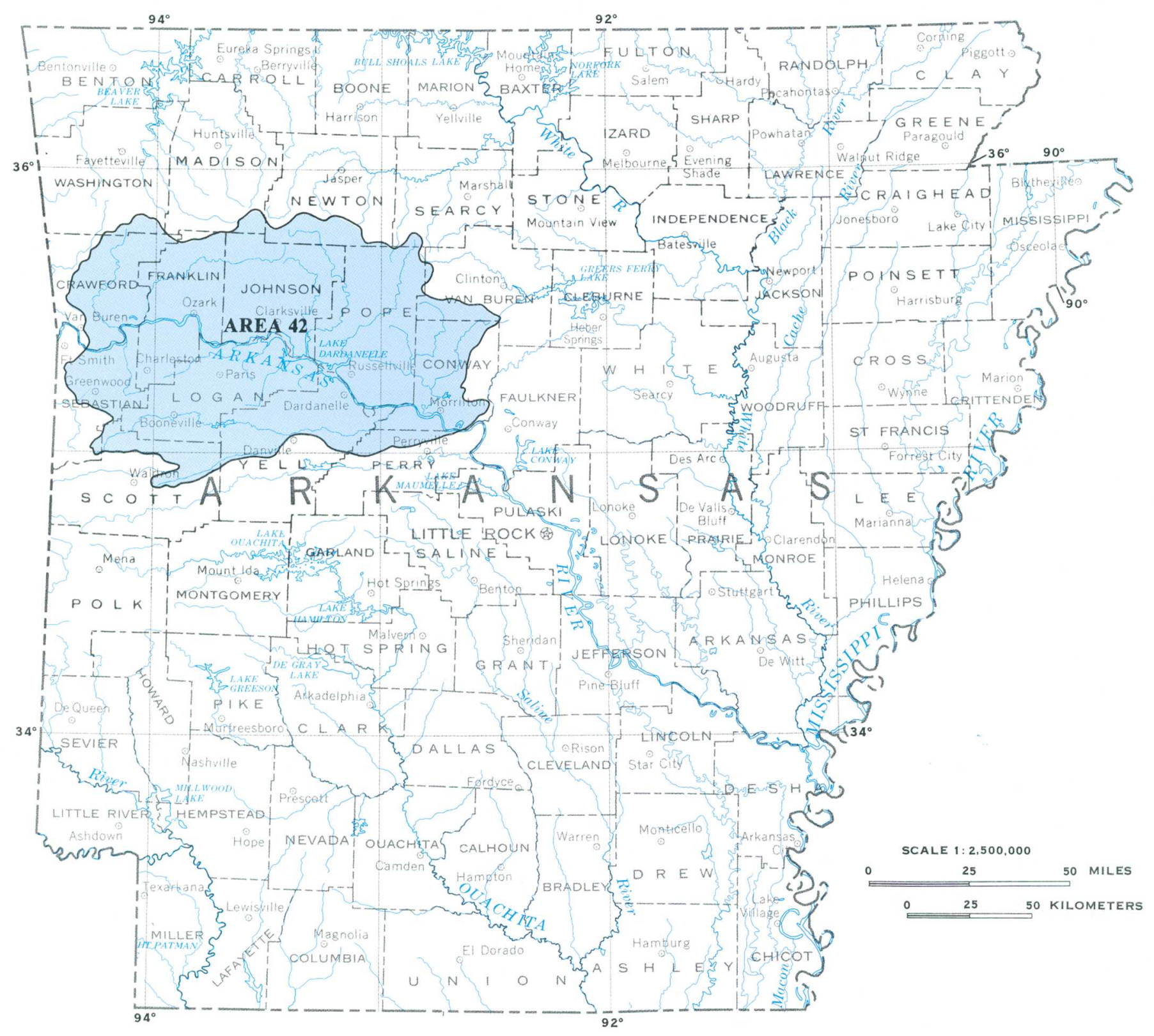

BASE FROM U.S. GEOLOGICAL SURVEY
UNITED STATES BASE MAP, I 980

Figure 1.1-1 Location of study area. 


\subsection{INTRODUCTION--Continued \\ 1.2 Project Area}

\section{Area 42 in Western Region of Interior Coal Province}

\section{Area 42 includes 5,100 square miles of the Interior Highlands \\ in western Arkansas.}

The western region of the Interior Coal province has been divided into seven hydrologic study areas (see front cover). The divisions are based on hydrology, location, and size. Each study area may comprise several drainage basins.

Area 42, in west-central Arkansas, is at the southern end of the western region, Interior Coal province. The area is in the Interior Highlands (Fenneman, 1938) and includes all or parts of Crawford, Washington, Madison, Newton, Searcy, Fran- klin, Johnson, Pope, Van Buren, Sebastian, Logan, Yell, Conway, Scott, and Perry Counties (fig. 1.2-1).

The area is drained by the Arkansas River and five of its principal tributaries, and several small tributaries. The topography of the area ranges from steep slopes in the north and southwest parts of the area (fig. 1.2-2) to rolling terrain in the rest of the area (fig. 1.2-3). 


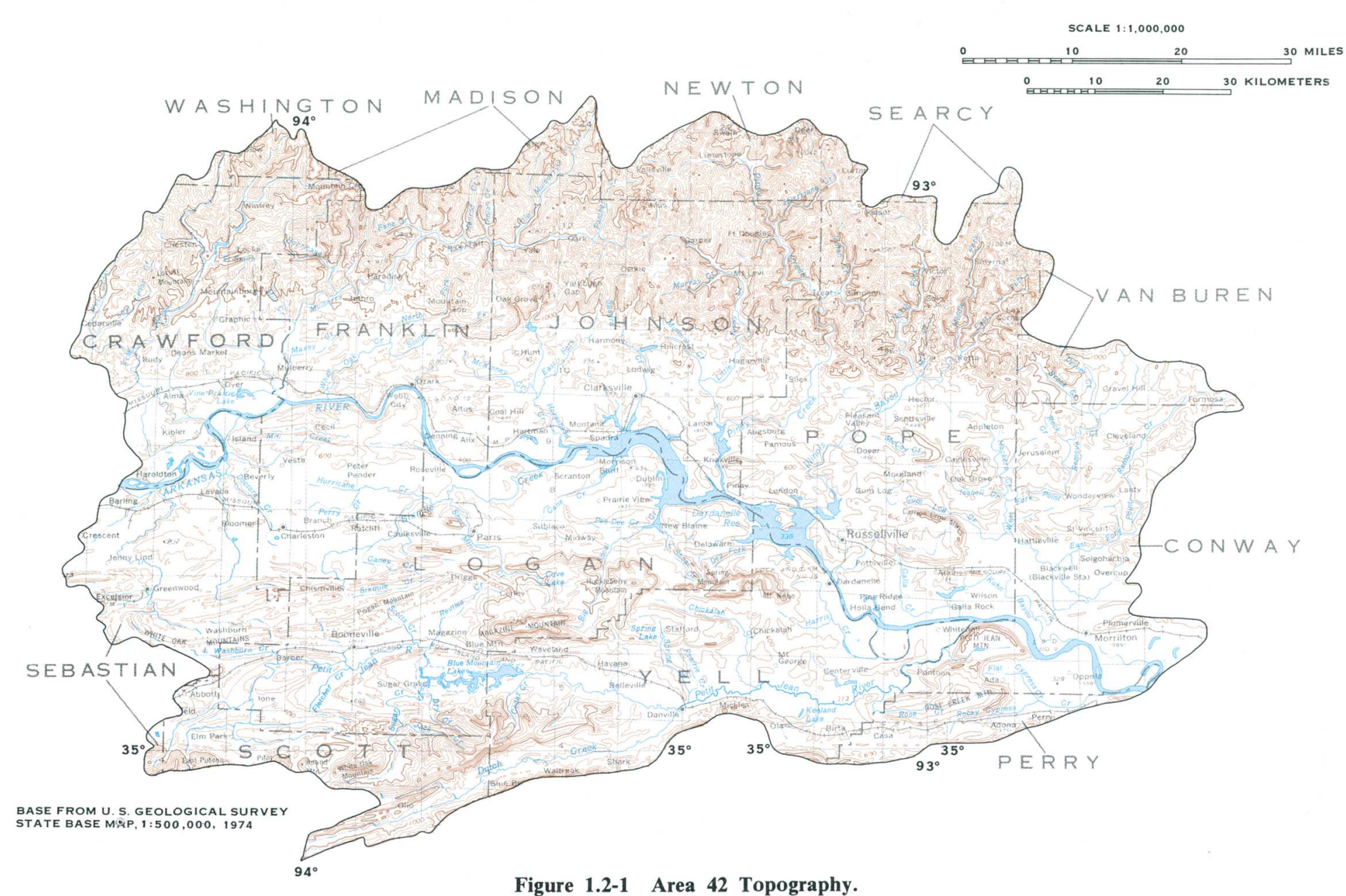

Figure 1.2-1 Area 42 Topography.

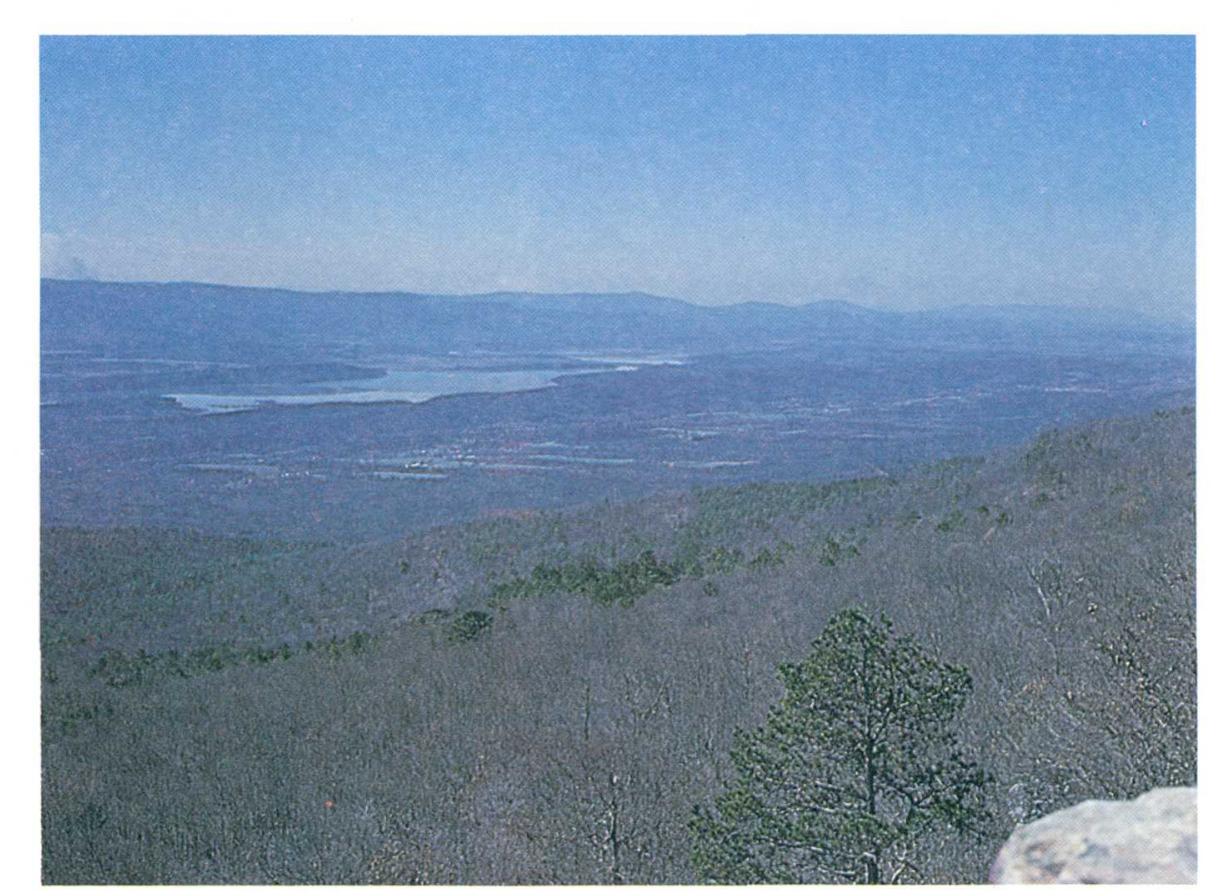

Figure 1.2-3 Rolling terrain in the area.

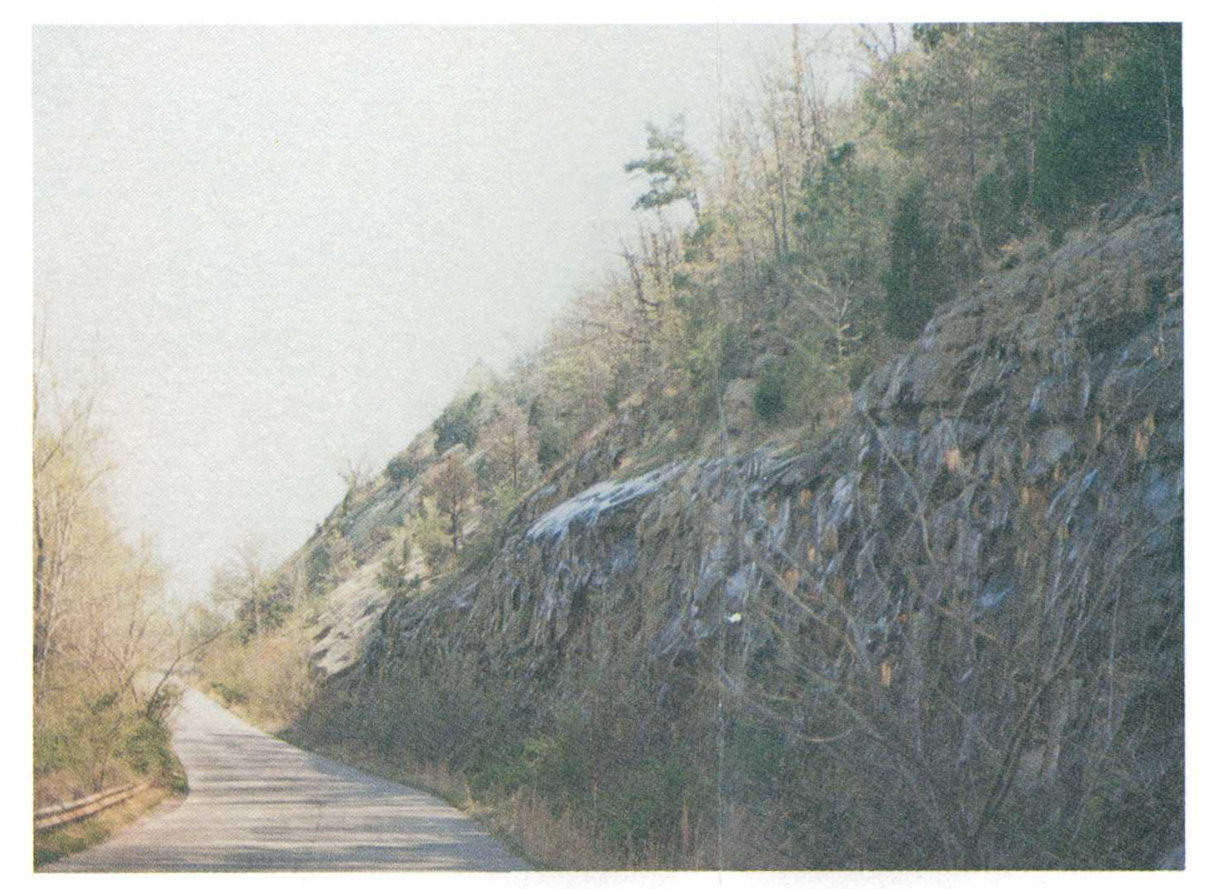

Figure 1.2-2 Steep slope in the area. 


\title{
1.0 INTRODUCTION--Continued \\ 1.3 Coal Mining and Reclamation
}

\section{Recoverable Coal Reserves are 665 Million Short Tons in West-Central Arkansas}

\author{
In 1971 initial State legislation was passed requiring reclamation of \\ strip-mined lands. Current mining and reclamation is regulated by \\ Acts of 1977 and 1979.
}

Approximately 2,100 million short tons of lowvolatile bitumunous and semianthracite coal reserves are in west-central Arkansas (Haley, 1960). Recoverable coal reserves are estimated to be 665 million short tons (U.S. Bureau of Mines, 1974). Coal mining in Arkansas began in 1870 and reached a peak in production in 1907 (figs. 1.3-1 and 1.3-2). Most coal mining was underground until 1958 when surface mining surpassed underground production (Bush and Gilbreath, 1978). After almost three decades of general decline, coal mining began increasing in the 1970's. Nearly all coal produced during the 1970's to the present time (1982) has been from surface mines. During 1980-81, there were nine active surface mines and no active underground mines in the area. An example of an active surface mine is shown in figure 1.3-3.

The State of Arkansas has enacted legislation requiring the reclamation of all lands being actively strip mined. Act 336 of 1977 required all open cut mine operators to obtain a permit and to submit a reclamation plan for land disturbed. Acts 134 and 647 of 1979 gave the Arkansas Department of Pollution Control and Ecology statutory authority to regulate surface coal mining and reclamation, including reclamation of lands affected by past surface coal mining operations not covered by reclamation laws, or that were mined thereafter. Many areas that were mined before reclamation legislation have not been reclaimed (fig. 1.3-4). Unreclaimed lands are commonly spoil piles and open or water-filled pits. As of 1977 , nearly 10,000 acres had been disturbed by surface mining. About 20 percent of the disturbed area had been reclaimed (Bush and Gilbreath, 1978). An example of reclamation is shown in figure 1.3-5. 

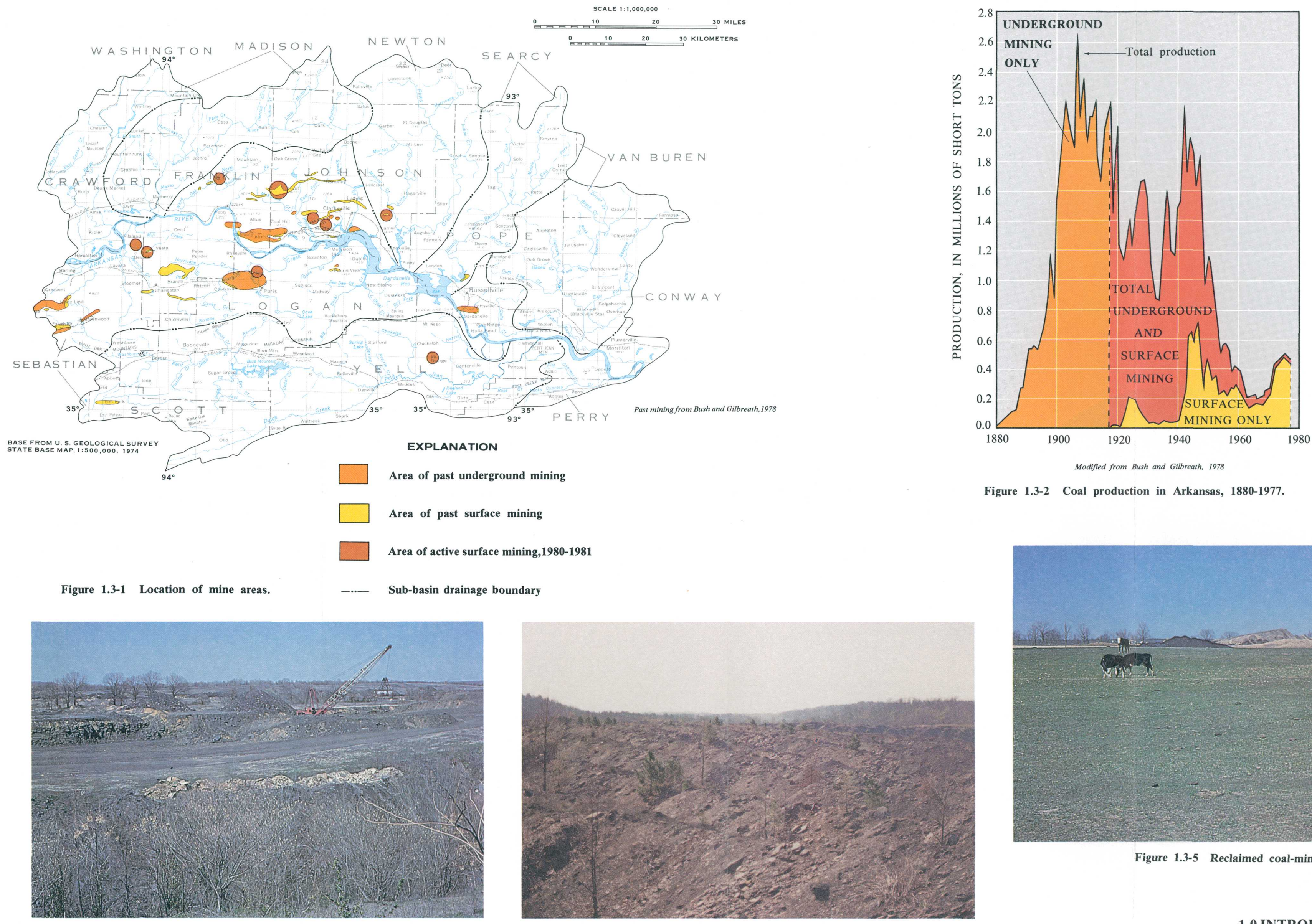

Figure 1.3-2 Coal production in Arkansas, 1880-1977.

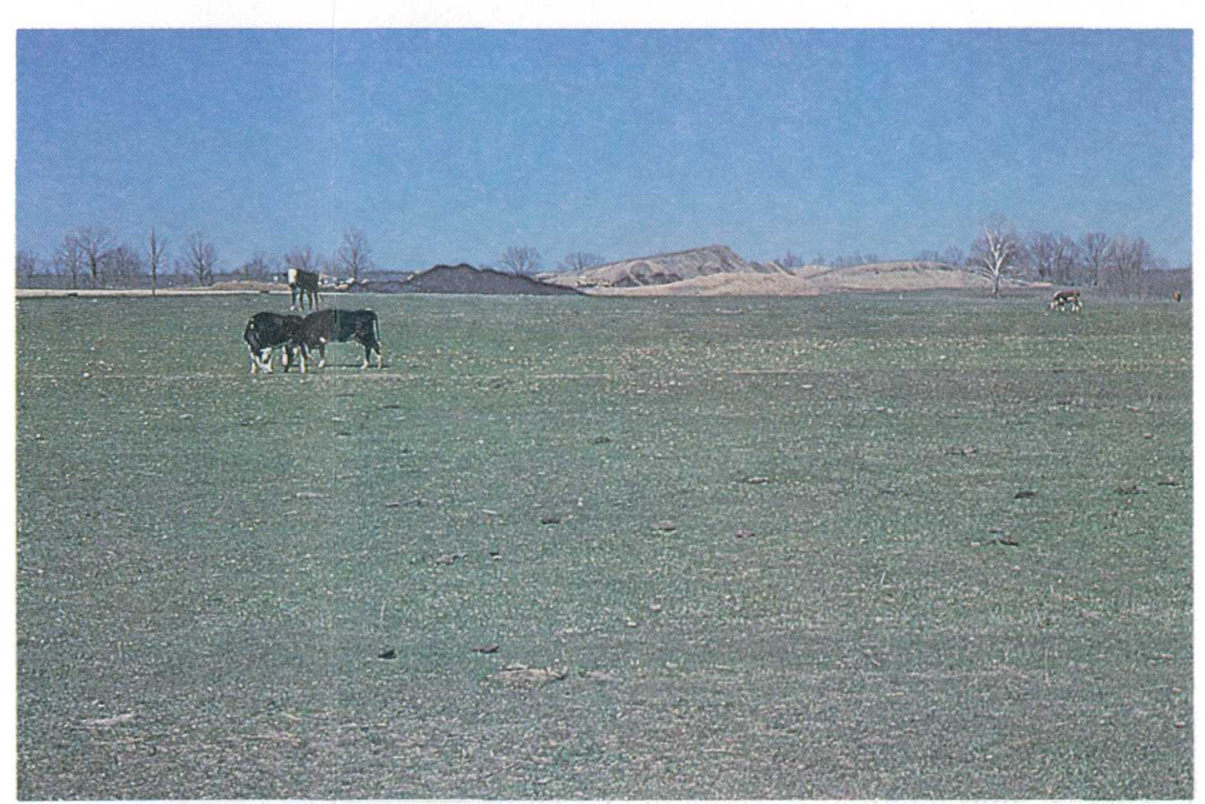

Figure 1.3-5 Reclaimed coal-mine site. 


\subsection{GENERAL FEATURES \\ 2.1 Geology}

\section{Sedimentary Rocks, Mostly of the Pennsylvanian System, Underlie the Area}

The rocks are mostly shale, siltstone and sandstone and are faulted and folded.

The sedimentary rocks cropping out in the area are all of the Pennsylvanian System, except for a few small exposures of shale and limestone of the Mississippian System in the northern part of the area, and alluvium of the Quaternary System along the Arkansas River (fig. 2.1-1). The rocks lie within the elongated Arkoma structural basin, with its long axis trending westwardly from the area into Oklahoma. Except for the alluvium, the rocks are extensively folded and faulted. Normal faults are mostly north of the Arkansas River, and thrust faults are mostly south of the Arkansas River. Access to minable coal beds is a function of the folding and faulting. For example, coal beds on the upthrown sides of faults will be nearer the land surface than coal beds on the downthrown sides of faults.

The rock composition, thickness, and stratigraphic position of the coal-bearing formations of the Pennsylvanian System are illustrated in figure 2.1-2. The uppermost formation, the Boggy, con- tains no coal. The underlying Savanna and McAlester Formations contain the principal coal reserves in the area. Most coal has been produced from the lower Hartshorne coal near the base of the McAlester Formation (Haley and others, 1979). The locations and thicknesses of the Lower Hartshorne coal are shown in figure 2.1-3. According to Haley (1960), the Lower Hartshorne coal ranges from 14 to 42 inches in thickness in more than one-half of its area of occurrence. Where mined, the Lower Hartshorne coal has averaged about 22 inches in thickness. Figure 2.1-4 shows an 18 inch exposure of the Lower Hartshorne coal. The Atoka Formation contains thin beds of coal but they are not of commercial value.

The alluvium along the Arkansas River is composed of clay, silt, sand, and gravel that ranges in thickness from about 40 feet at the western edge of the area to about 70 feet at the eastern edge. 

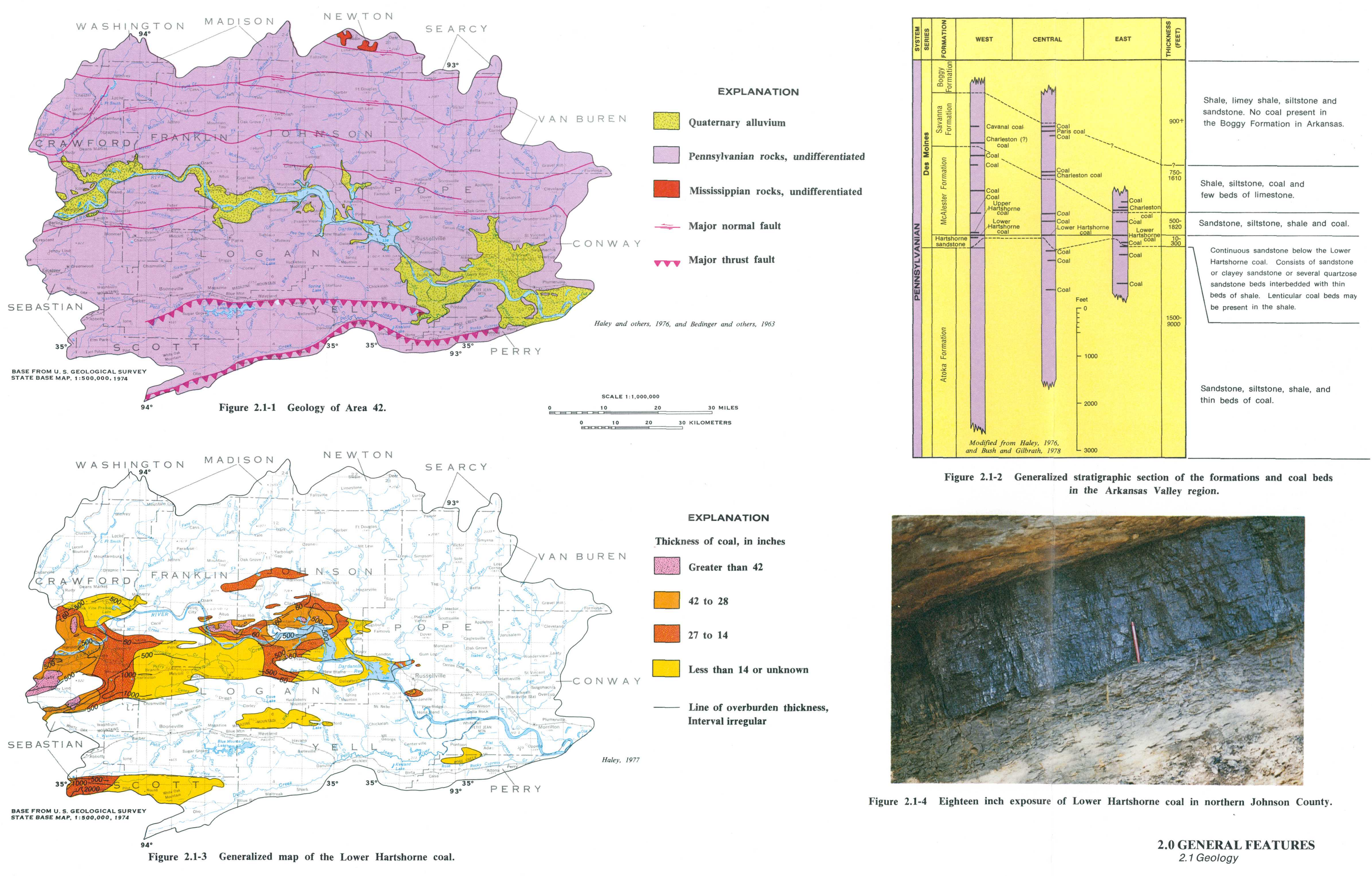

Figure 2.1-2 Generalized stratigraphic section of the formations and coal beds in the Arkansas Valley region.

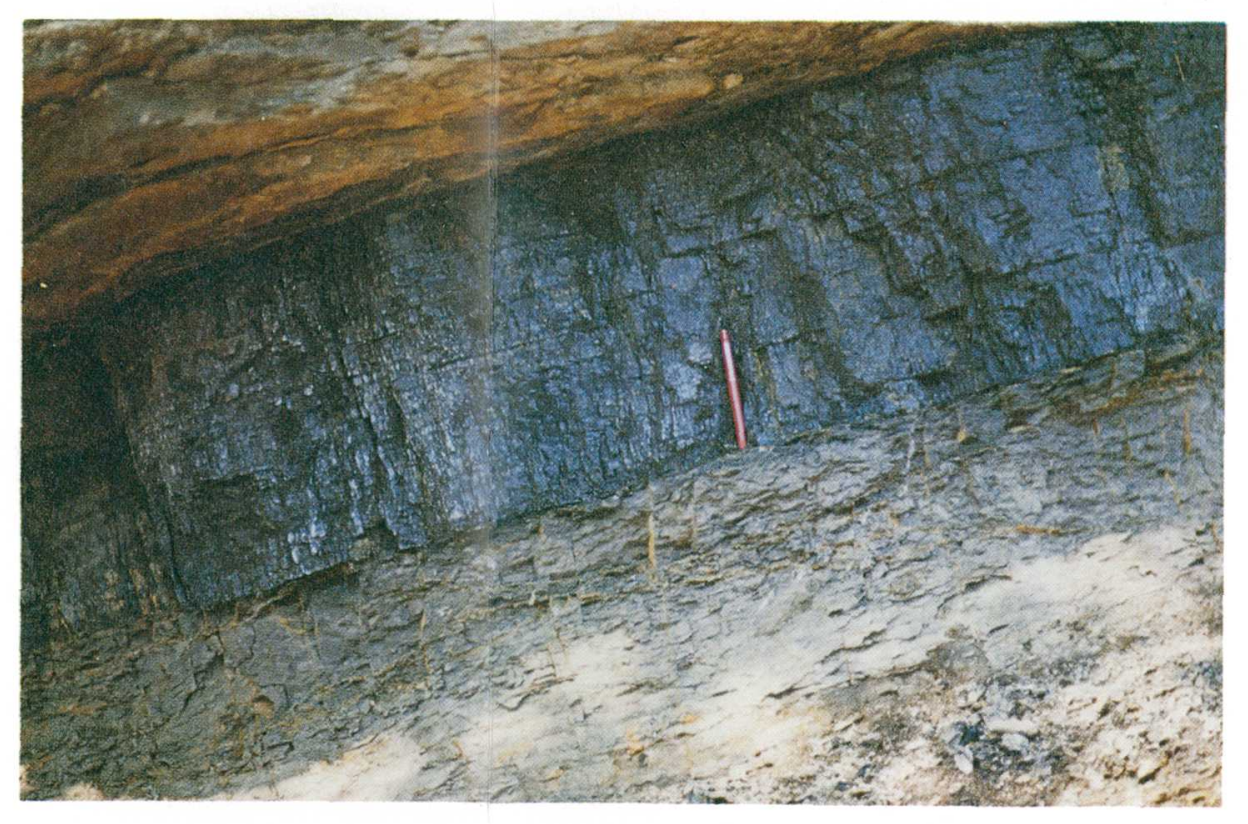

Figure 2.1-4 Eighteen inch exposure of Lower Hartshorne coal in northern Johnson County. 


\subsection{GENERAL FEATURES--Continued \\ 2.2 Surface Drainage}

\section{Arkansas River and its Principal Tributaries Drain Area 42}

\section{Area 42 is drained by the Arkansas River, five of its principal tributaries, and several small tributaries.}

Area 42 comprises an area of 5,100 square miles, all of which is drained by the Arkansas River and its tributaries (fig. 2.2-1). The principal tributaries are: The Mulberry River, Big Piney Creek, Illinois Bayou, the Petit Jean River and Point Remove Creek.
The principal tributaries drain about 3,050 square miles. The remainder of the area, about 2,050 square miles, is drained by smaller tributaries. Drainage areas at selected locations are given by Sullavan and Terry (1970).

Drainage areas of the Arkansas River and its principal tributaries are as follows:

Stream

Area (square miles)

Arkansas River (entering Area 42)

150,547

Arkansas River (leaving Area 42) 155,629

Big Piney Creek

537

Illinois Bayou

391

Mulberry River

511

Petit Jean River

1,083

Point Remove Creek

530 


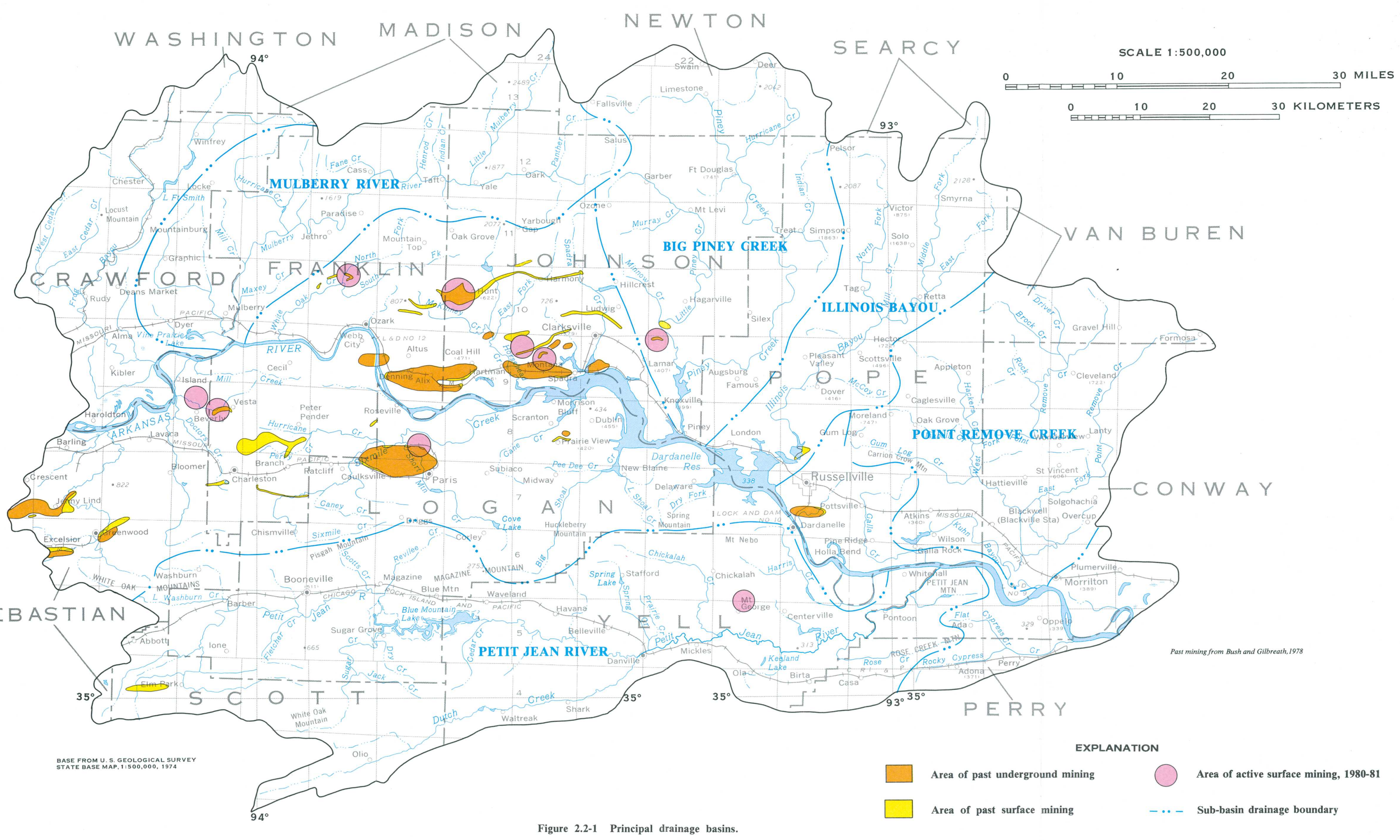




\subsection{GENERAL FEATURES--Continued \\ 2.3 Land Use}

\section{Most of Land is Farmed or Forested}

\section{Forests and farmland cover most of Area 42; barren land, and surface mining activity covers less than 1 percent.}

Six land-use categories have been identified for Area 42 (fig. 2.3-1). Land-use categories are described in the list that follows.

- Agriculture--row crop, pasture, small grains, and barren rural lands.

- Urban--residential, commercial, industrial, institutions, and recreational. lots.

- Forested--commercial forest and wooded farm

- Water--lakes, ponds, and rivers.

- Wetland--marsh or bog areas.

- Barren--sand, bare rock, mined and unreclaimed.

Land use affects surface-water flow and ground-water recharge and discharge, and water quality. Changes in land use will alter the hydrologic interactions in an area. Understanding the distribution of different land uses aids in understanding existing water data. For example, surface mining, road construction, timber harvesting, and field preparation of cropland, may result in faster runoff and increased erosion and sediment loading to streams, and develop recharge to ground water. Conversely, revegetation of disturbed land may reduce runoff, increase infiltration, and reduce sediment loading.

Land-use and land-cover maps and other information may be found in U.S. Geological Survey open-file reports entitled "Land Use Series." Information on the series is available from the National Cartographic Information Center, U.S. Geological Survey, National Center, Reston, Virginia 22092. 


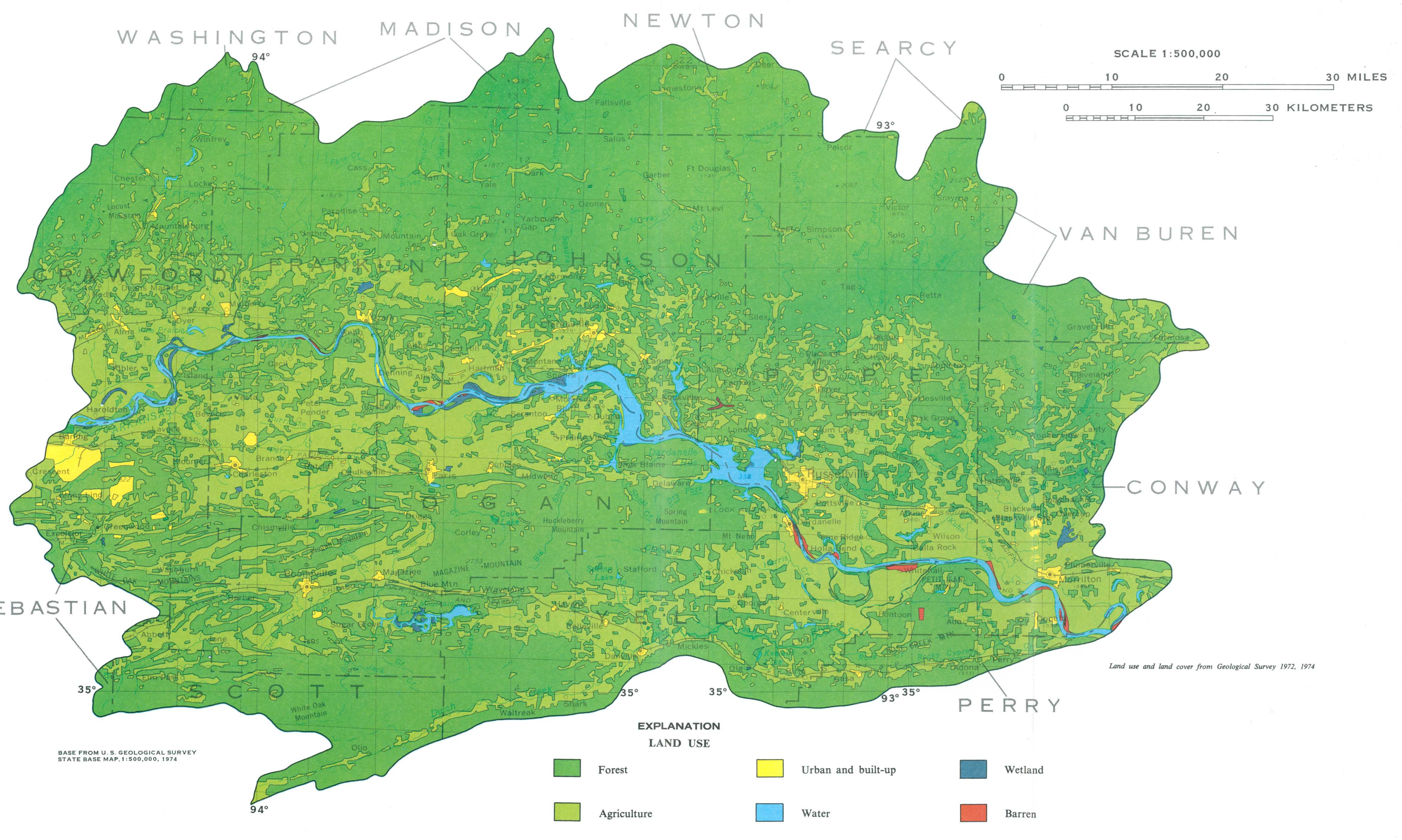




\title{
2.0 GENERAL FEATURES--Continued 2.4 Soils
}

\section{Soils are Generally Acidic, have Low to Moderate Permeability, and are Subject to Erosion}

\author{
Soil $\mathrm{pH}$ ranges from 3.6 to 8.4 units, and soil erosion ranges \\ from 1 to 5 tons per acre per year.
}

Ten soil associations are in Area 42 (fig. 2.4-1). Each association is identified by a unique number and pertinent soil features are summarized in table 2.4-1. Soil associations 11 and 13 through 17, developed on bedrock, are acidic, with $\mathrm{pH}$ ranging from 3.6 to 6.5 units. Soil associations $38,39,41$, and 42 , of alluvial origin, have a $\mathrm{pH}$ ranging from 3.6 to 8.4 units. Permeability of these soils ranged from less than 0.06 to 6.0 inches per hour.

Erosion factors $t$ and $k$ indicate the susceptibility of soils to erosion. Erosion factor $t$ is an estimate of the maximum average annual rate of soil erosion by wind and water that can occur throughout a sus- tained period without affecting crop productivity. Erosion factor $t$ varies between 1 and 5 tons per acre per year in Area 42. Erosion factor $k$ indicates the susceptibility of a soil to sheet-and-rill erosion by water. The higher the $k$ value, the more susceptible the soil is to erosion by water. In Area 42, the $k$ factor ranges from 0.17 to 0.49 .

The soils map and soil-association descriptions are very generalized. Detailed information for most individual counties is available from the U.S. Soil Conservation Service, 700 West Capital Avenue, Little Rock, Arkansas 72201-3287. 


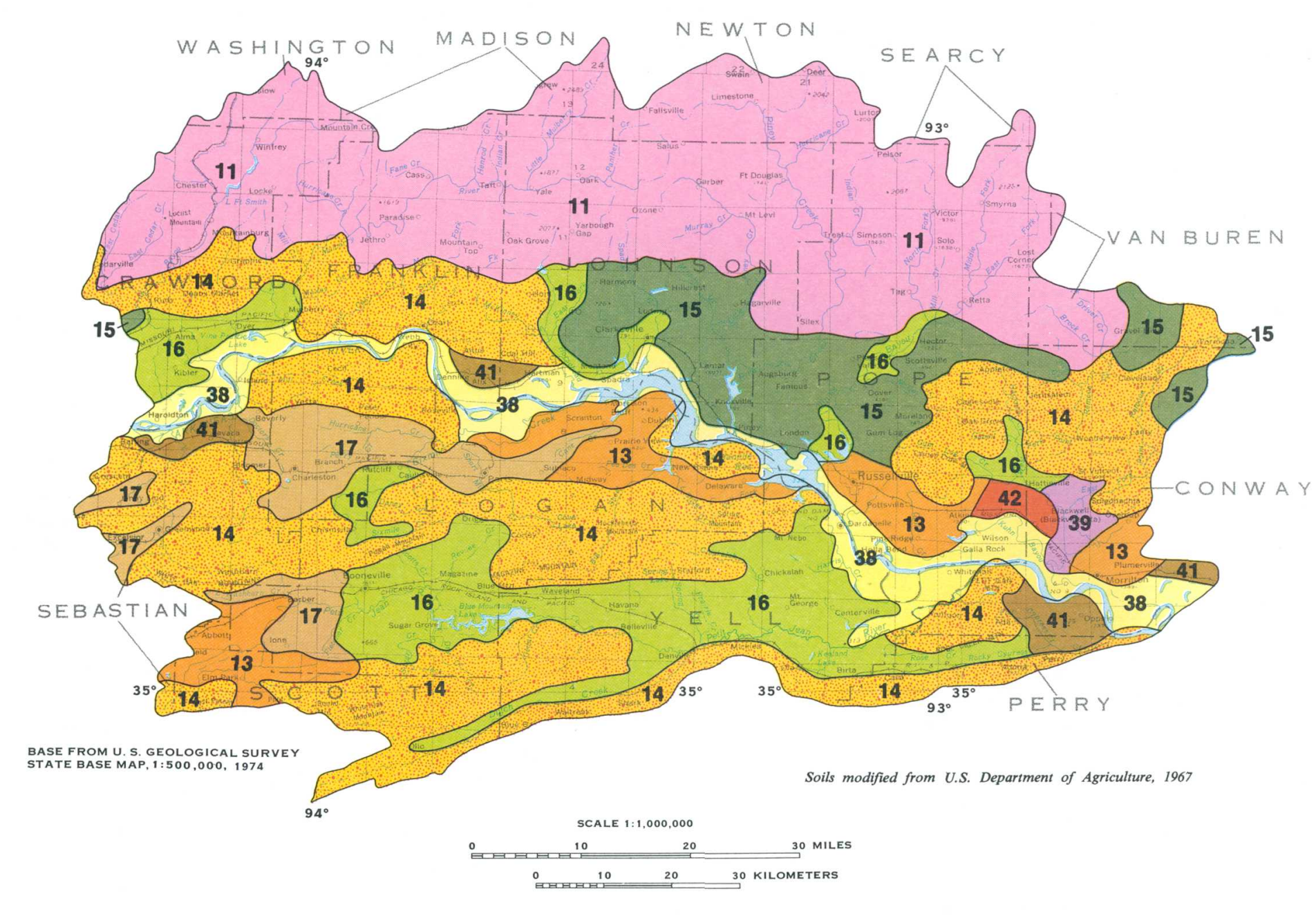

Figure 2.4-1 Generalized soil associations.

\begin{tabular}{|c|c|c|c|c|c|c|c|c|}
\hline & $\begin{array}{l}\text { oil association and } \\
\text { physical description }\end{array}$ & $\begin{array}{l}\text { Soil depth } \\
\text { and th } \\
\text { depth to } \\
\text { pedrock } \\
\text { (inches) }\end{array}$ & (unit) & $\begin{array}{l}\text { Pemeability } \\
\text { (inches per hour) }\end{array}$ & $\begin{array}{l}\text { Available } \\
\text { water capacity } \\
\text { (inches per inch) }\end{array}$ & $\begin{array}{c}\text { Slope } \\
\text { (percent) }\end{array}$ & 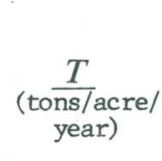 & / \\
\hline 11 & $\begin{array}{l}\text { Enders-Holston } \\
\text { Deep soils over } \\
\text { shale and sand- } \\
\text { stone }\end{array}$ & 32->80 & $3.6-5.5$ & $<0.06-2.0$ & $0.08-0.22$ & $3-65$ & $3-5 \quad 0$ & $0.24-0.43$ \\
\hline 13 & $\begin{array}{l}\text { Leadvale-Taft- } \\
\text { Montevallo } \\
\text { Deep and shallow } \\
\text { soils that have } \\
\text { a fragipan }\end{array}$ & $10->80$ & $4.5-6.0$ & $0.06-2.0$ & $0.01-0.22$ & $0-20$ & $2-3 \quad 0$ & $0.24=0.25$ \\
\hline 14 & $\begin{array}{l}\text { Mountainberg-Enders } \\
\text { Shallow and deep } \\
\text { soils over shale } \\
\text { and sandstone }\end{array}$ & 12-59 & $3.6-6.0$ & $<0.06-6.0$ & $0.05-0.22$ & $20-40$ & $1-3 \quad 0$ & $0.17-0.43$ \\
\hline 15 & $\begin{array}{l}\text { Linker-Mountainberg } \\
\text { Hartsells } \\
\text { Deep and shallow } \\
\text { soills over shale } \\
\text { and sandstone }\end{array}$ & $12-40$ & $3.6-6.0$ & $\begin{array}{ll}0.6 \quad 6.0\end{array}$ & $0.05-0.20$ & $1-65$ & $1-3 \quad 0$ & $0.17-0.32$ \\
\hline 16 & $\begin{array}{c}\text { Pickwick-Leadvale } \\
\text { Deep soils that } \\
\text { have a fragipan }\end{array}$ & $48->80$ & $4.5-5.5$ & $0.06-2.0$ & $0.06-0.22$ & $1-8$ & $3-5 \quad 0$ & $0.24-0.43$ \\
\hline 17 & $\begin{array}{l}\text { Faulkner } \\
\text { Deep soils over } \\
\text { shale and sand- } \\
\text { stone }\end{array}$ & $>80$ & $4.5-6.5$ & $0.06-.6$ & $0.16-0.22$ & $1-8$ & 4 & $0.24-0.43$ \\
\hline 38 & $\begin{array}{l}\text { Coushatta-No rwood } \\
\text { Deep soils in } \\
\text { alluvial bottom- } \\
\text { lands and } \\
\text { terraces }\end{array}$ & $>80$ & $5.6-8.4$ & $0.6-2.0$ & $0.14-0.23$ & $0-3$ & 5 & $0.32-0.43$ \\
\hline 39 & $\begin{array}{l}\text { Portland-Perry } \\
\text { Deep, wet soils in } \\
\text { alluvial "back- } \\
\text { water" deposits }\end{array}$ & $>80$ & $4.5-8.4$ & $<0.06-2.0$ & $0.12-0.24$ & $0-3$ & 5 & $0.24-0.43$ \\
\hline 41 & $\begin{array}{l}\text { Gallion-Muskogee } \\
\text { Deep soils in } \\
\text { alluvial terraces }\end{array}$ & $>80$ & $4.5-8.4$ & $0.06-2.0$ & $0.14-0.24$ & $0-8$ & 5 & $0.32-0.43$ \\
\hline 42 & $\begin{array}{l}\text { Acadia-Wrightsville } \\
\text { Deep, poorly- } \\
\text { drai ned wet soils } \\
\text { in alluvial } \\
\text { terrraces }\end{array}$ & $>80$ & $3.6-8.4$ & $<0.06-2.0$ & $0.14-0.24$ & $0-1$ & 4.5 & $0.32-0.49$ \\
\hline
\end{tabular}




\subsection{GENERAL FEATURES--Continued \\ 2.5 Precipitation}

\section{Area has a Moist Temperate Climate}

\section{Normal annual rainfall varies from 42 to 50 inches.}

Area 42 has a moist temperate climate and a normal annual rainfall that varies from 42 inches in the southwestern part of the area to 50 inches in the eastern part (fig. 2.5-1). Precipitation occurs mostly as showers during the summer and as general rain and some snow during the late fall, winter, and early spring.

Distribution of rainfall by months for the $\mathrm{Na}$ tional Oceanic and Atmospheric Administration Weather Station at Subiaco near the center of Area 42 , is shown in figure $2.5-2$. The mean monthly rainfall is fairly well distributed throughout the year; April and May are the wettest months, and January and February are the driest.

The area is subject to heavy local rains that may produce a twenty-four hour rainfall in excess of 10 inches. There are frequent periods of dry weather and occasional severe droughts. Precipitation occurs in the area on the average of 100 days a year. Snowfall averages about 1 foot a year. 

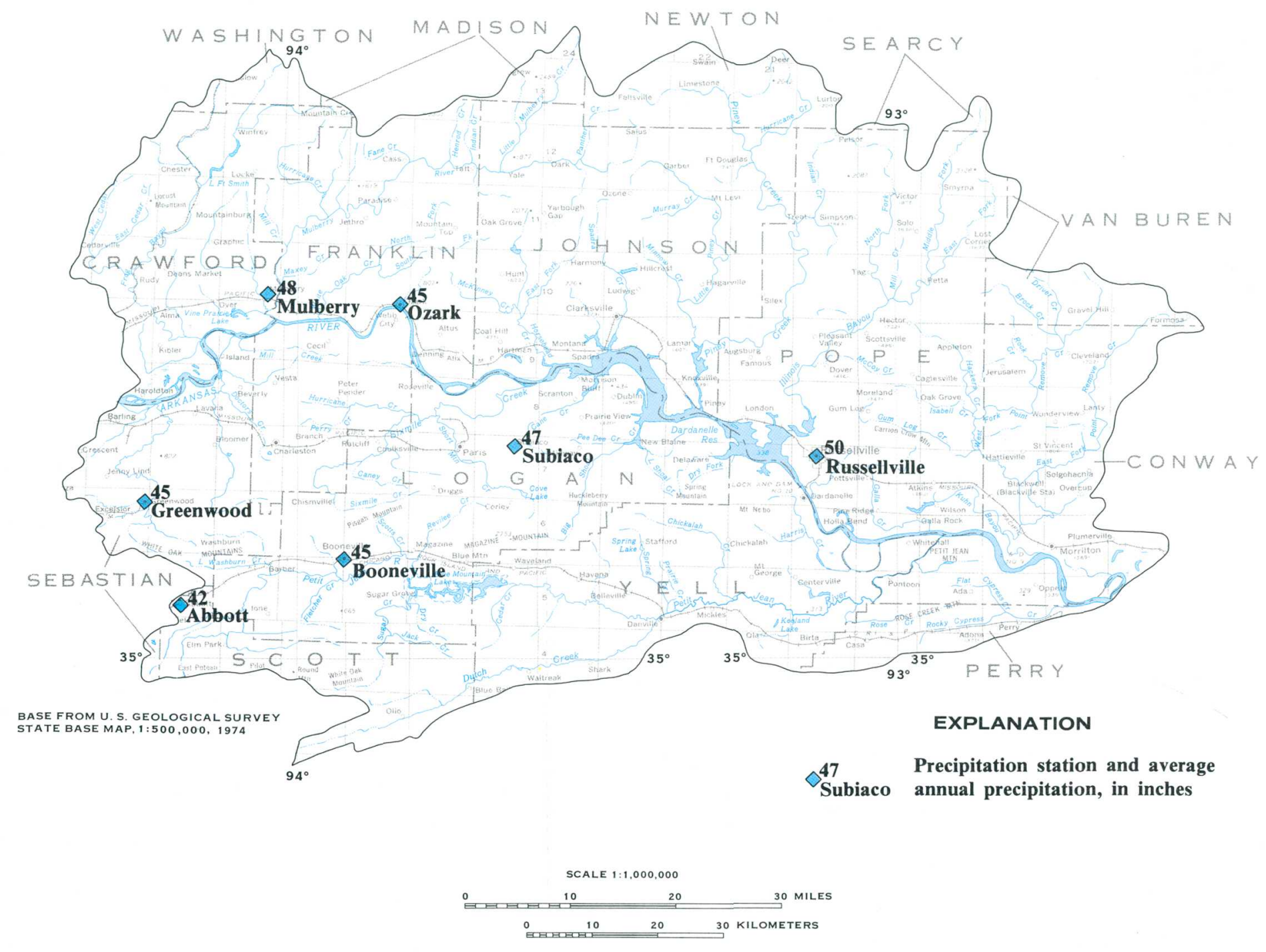

Figure 2.5-1 Normal annual precipitation, in inches (1941-70).

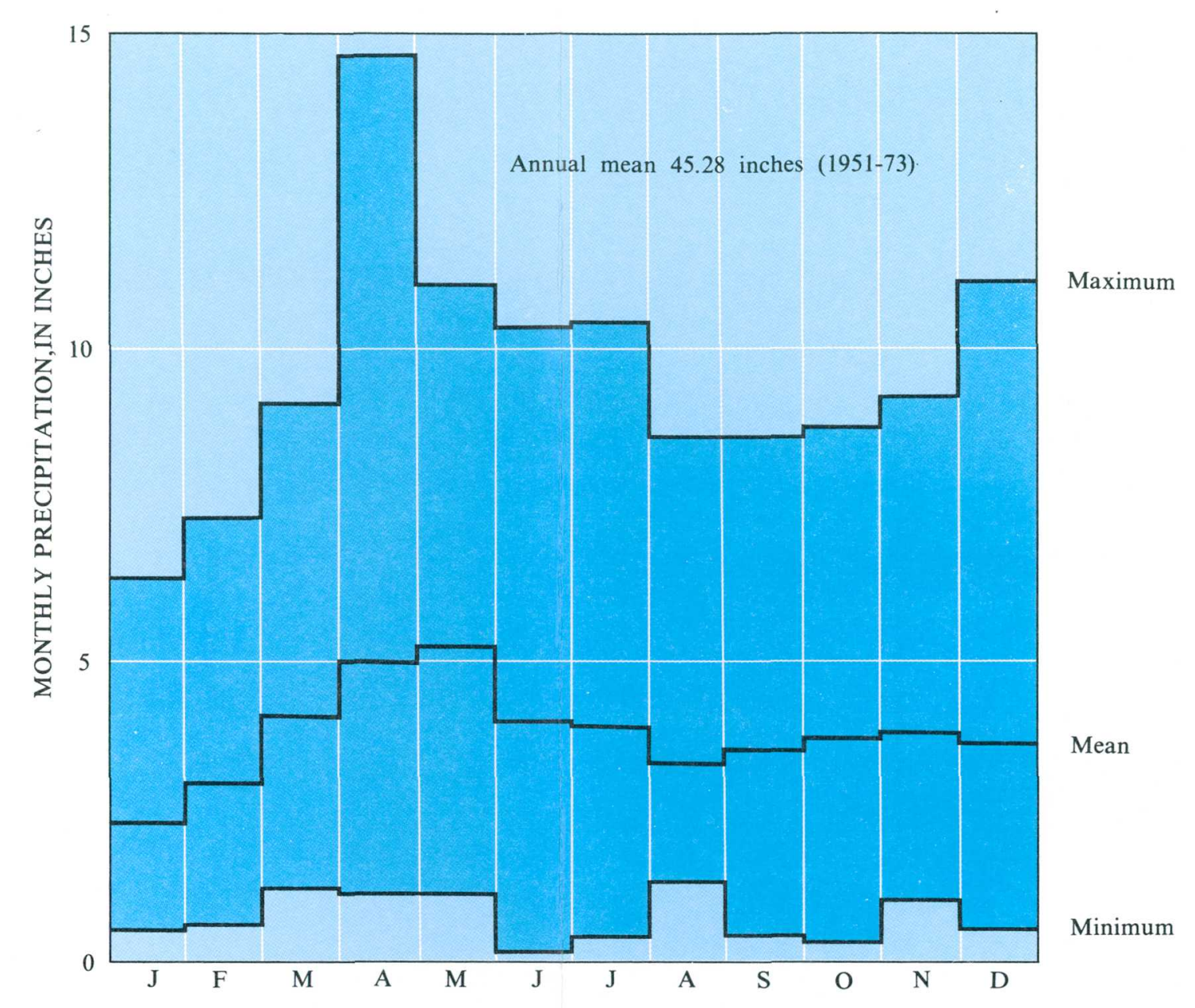

Based on records for the $1951-73$ period

Climatologicial data from
U.S. Department of Commerce, 1975

Extremes of record, in inches

Maximum monthly precipitation:

thly precipitation: $\quad .12$

Maximum precipitation in 24 hours: 5.48

Maximum monthly snowfall:

Figure 2.5-2 Precipitation data for Subiaco, Arkansas. 


\title{
3.0 WATER USE
}

\section{Principal Uses of Water were for Electric Power Generation, Public Supplies and Irrigation}

\begin{abstract}
About 28,200 million gallons of water per day were used for thermoelectricand hydroelectric-power generation, 37 million gallons per day were used for public supplies, and 26 million gallons per day were used for irrigation.
\end{abstract}

\begin{abstract}
About 28,310 million gallons of water were used per day in Crawford, Franklin, Johnson, Pope, Conway, Yell, Logan, and Sebastian Counties in Area 42 during 1980 (A. H. Ludwig, U.S. Geological Survey, written commun., 1981) (fig. 3.0-1). Of this total, 28,212 million gallons per day were used from the Arkansas River for thermoelectric- and hydrolelectric-power generation (figs. 3.0-2 and 3.0-3). Most of the water used for power generation was returned to the river.
\end{abstract}

The second largest use of 37 million gallons per day was for public supplies. About 93 percent of the water for public supplies came from reservoirs on tributaries of the Arkansas River, and about 7 percent was from ground water. The third largest use of 26 million gallons per day was for irrigation; 68 percent was ground water and 32 percent was surface water. Most of the ground water used was from the alluvium along the Arkansas River.

Wells, streams, and small reservoirs supplied 17.4 million gallons per day for numerous rural users in the area. Other uses of water were for self-supplied industry (2.2 million gallons per day), fish and minnow farms (3.6 million gallons per day), and navigation and recreation on the Arkansas River. 

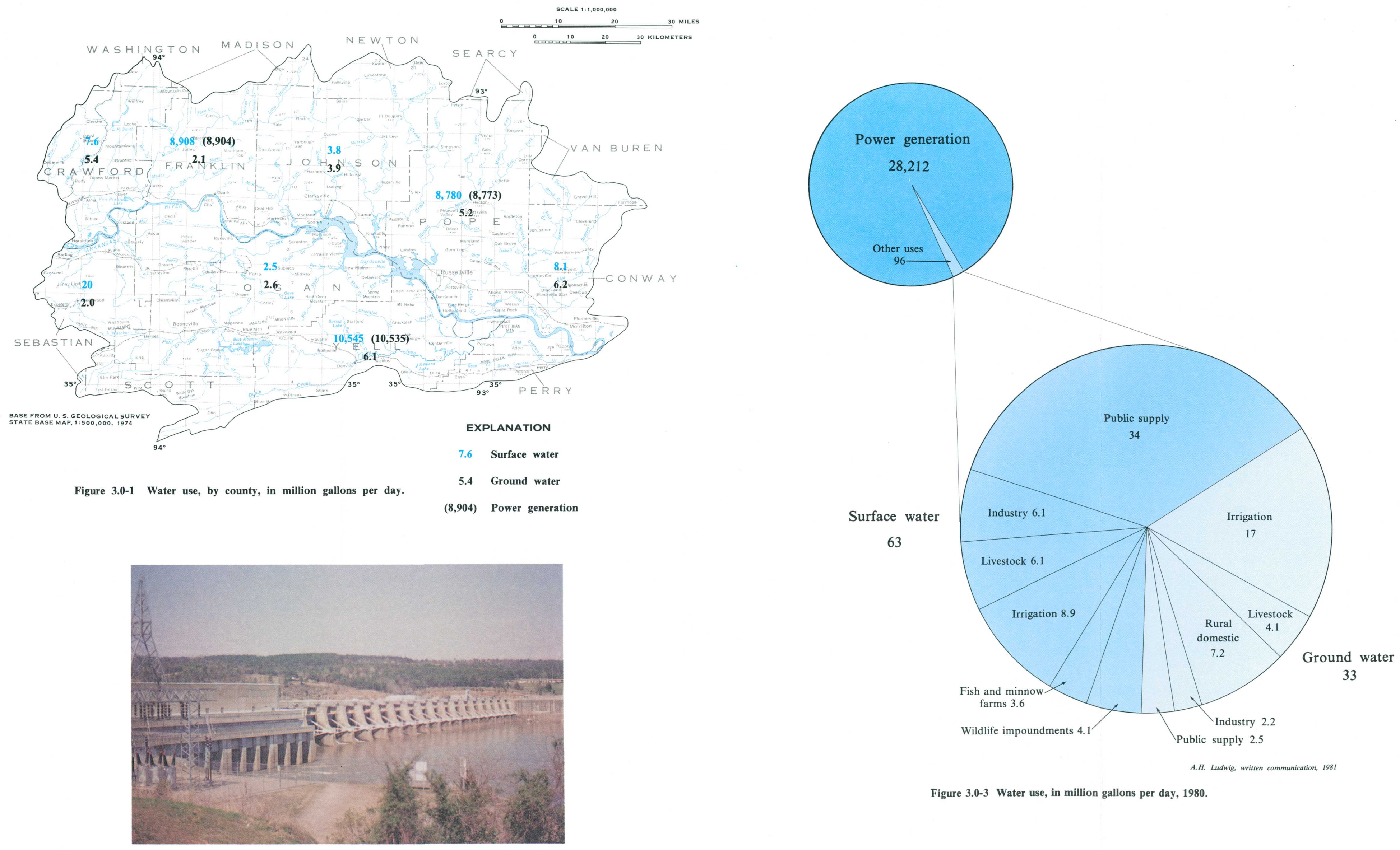

Figure 3.0-3 Water use, in million gallons per day, 1980.

Figure 3.0-2 Hydroelectric power generating dam on the Arkansas River. 


\subsection{STREAMFLOW \\ 4.1 Streamflow Data Network}

\section{Streamflow Information is Available for 44 Locations}

The U.S. Geological Survey maintains an active network of 18 stations in the area for which streamflow data are available.

Streamflow in Area 42 has been recorded for 44 active and inactive streamflow stations (fig. 4.1-1). Currently 6 continuous-streamflow record gaging stations and 12 partial-record (annual maximum streamflow) stations are operated by the U.S. Geological Survey. Information for the stations shown on the map is in table 4.1-1. Data for active stations are published annually in "Water Resources Data for
Arkansas" and are available from the U.S. Geological Survey, 2301 Federal Office Building, Little Rock, Arkansas 72201-3287, phone (501) 378-6391. These data are also available from computer storage through the National Water Data Exchange (NAWDEX). 


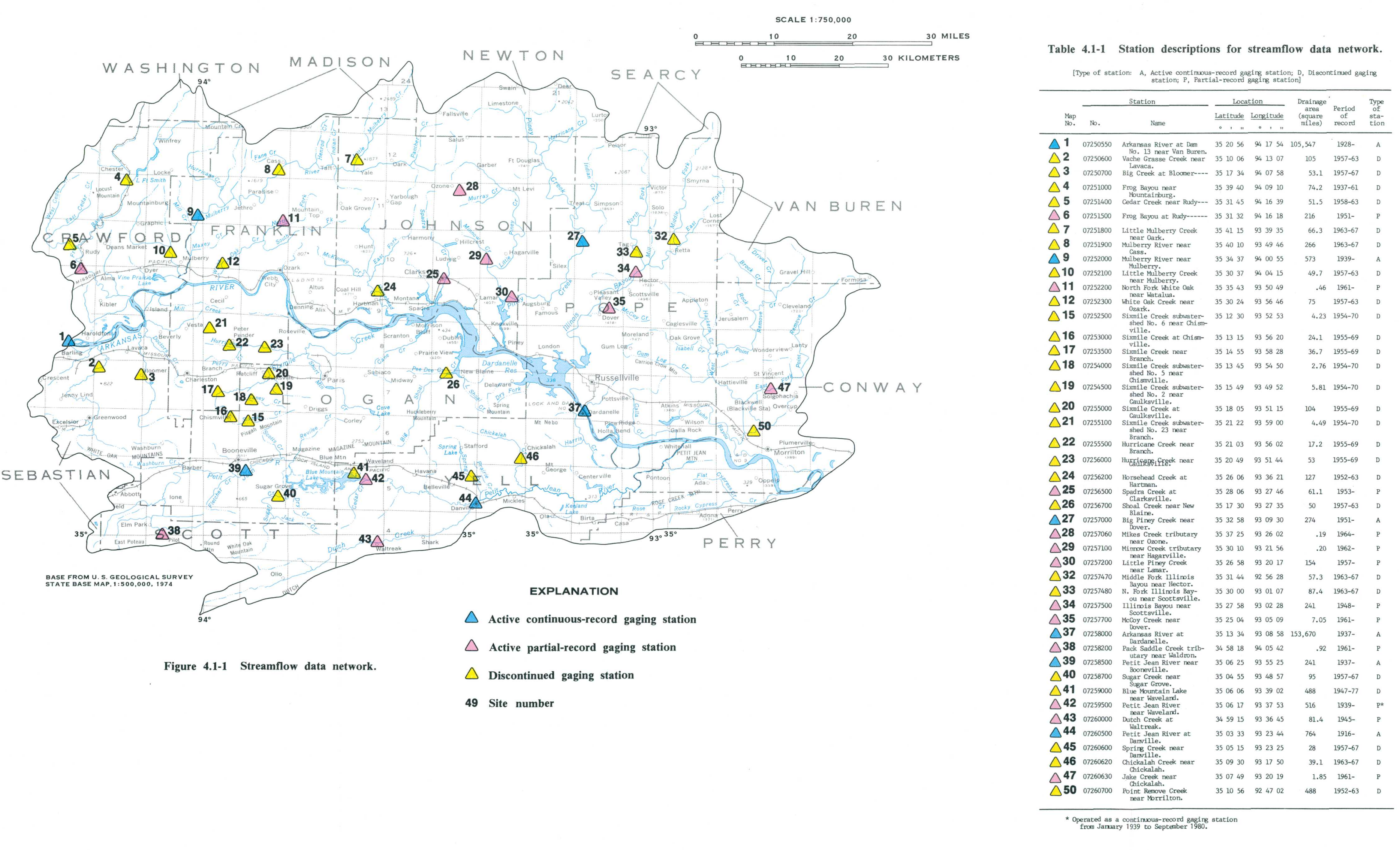




\subsection{STREAMFLOW--Continued \\ 4.2 Streamflow Variation}

\section{Streamflow Varies with Time and Location}

\section{Streamflow variation is related to rainfall and evapotranspiration.}

Streams discharge between 1.0 and 1.6 cubic feet per second per square mile of drainage area (fig. 4.2-1). Average annual runoff from the area ranges from 14 inches at lower altitudes to 24 inches in mountainous areas (Patterson, 1967).

Streamflow varies with time at a given location due to changes in precipitation occurrences and their intensity and duration, air temperature, relative humidity, and other weather factors. Variations in streamflow with location are due to differences in climate, topography, and geology.

The important meteorological factors affecting streamflow are precipitation (fig. 4.2-2) and air temperature. A typical streamflow hydrograph for Big Piney Creek near Dover (site 27) for the 1974 water year illustrates the variations caused by short-term weather fluctuations and seasonal trends (fig. 4.2-3). Precipitation is the cause of day-to-day streamflow variations. When precipitation occurs streamflow rapidly rises, reaches a peak, falls rapidly, and gradually decreases to a point where most of the flow is derived from ground water inflow. Streamflow variations within a year are caused by largely predictable seasonal changes in weather. The seasonal streamflow variations are similar on most streams in Area 42. The hydrograph illustrates a yearly cycle of streamflow: The characteristic low flow of October; increase in streamflow through November as evapotranspiration decreased; the effects of rains from December through May; and recession of flow in June through September as rainfall decreased and evapotranspiration increased. 


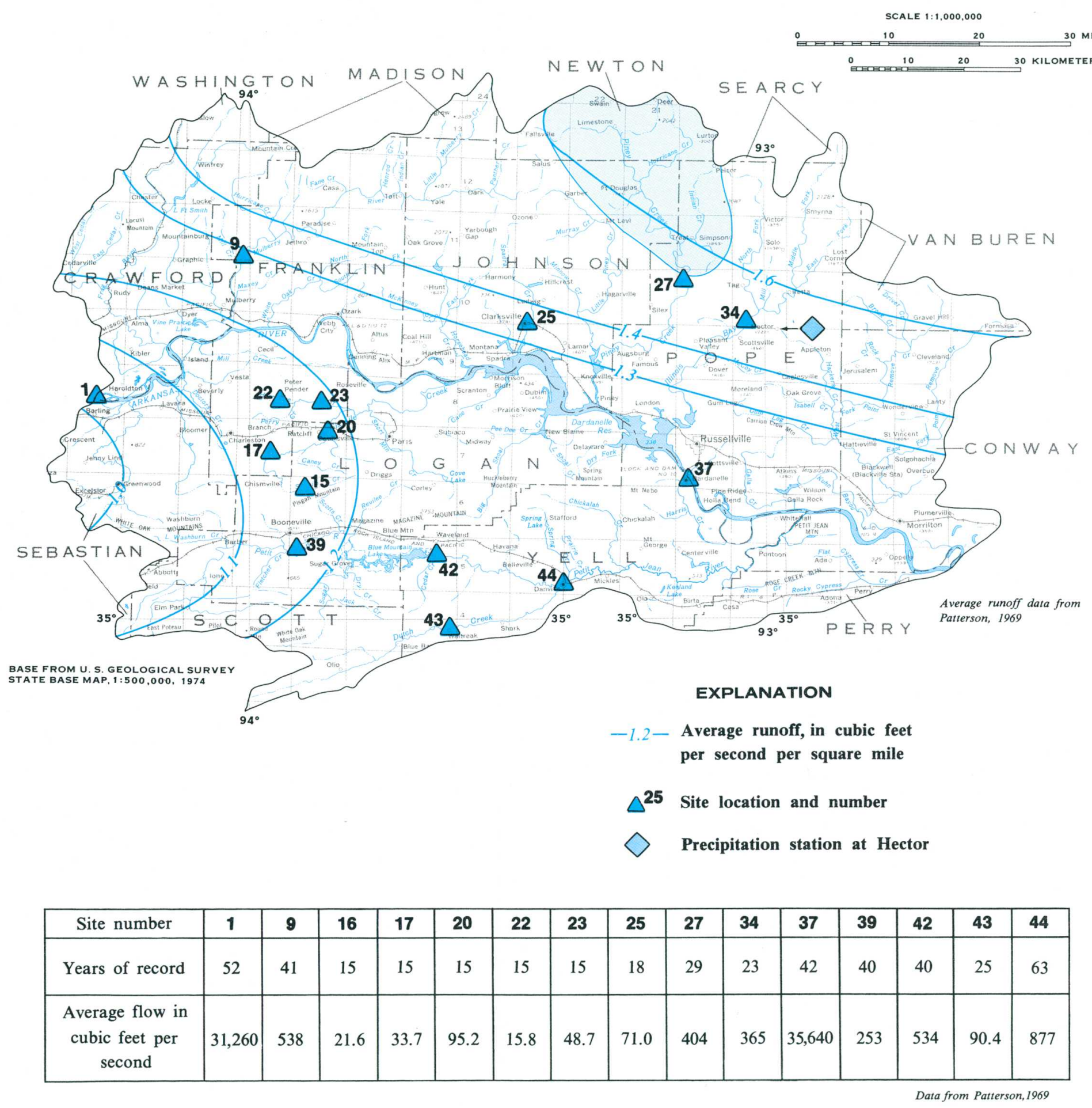

Figure 4.2-1 Average annual flow and average annual runoff.

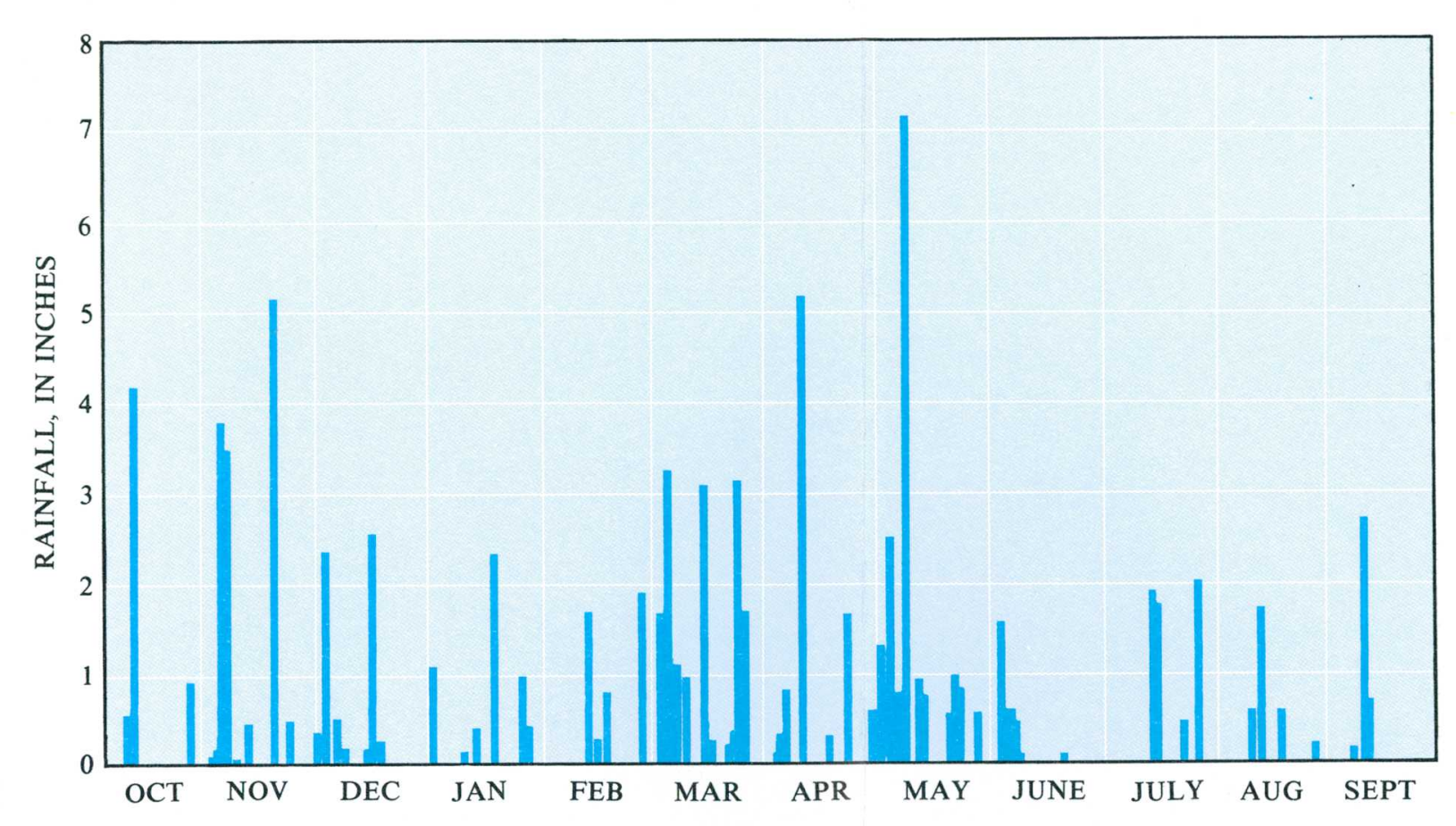

Figure 4.2-2 Precipitation data for Hector, October 1977 to September 1978

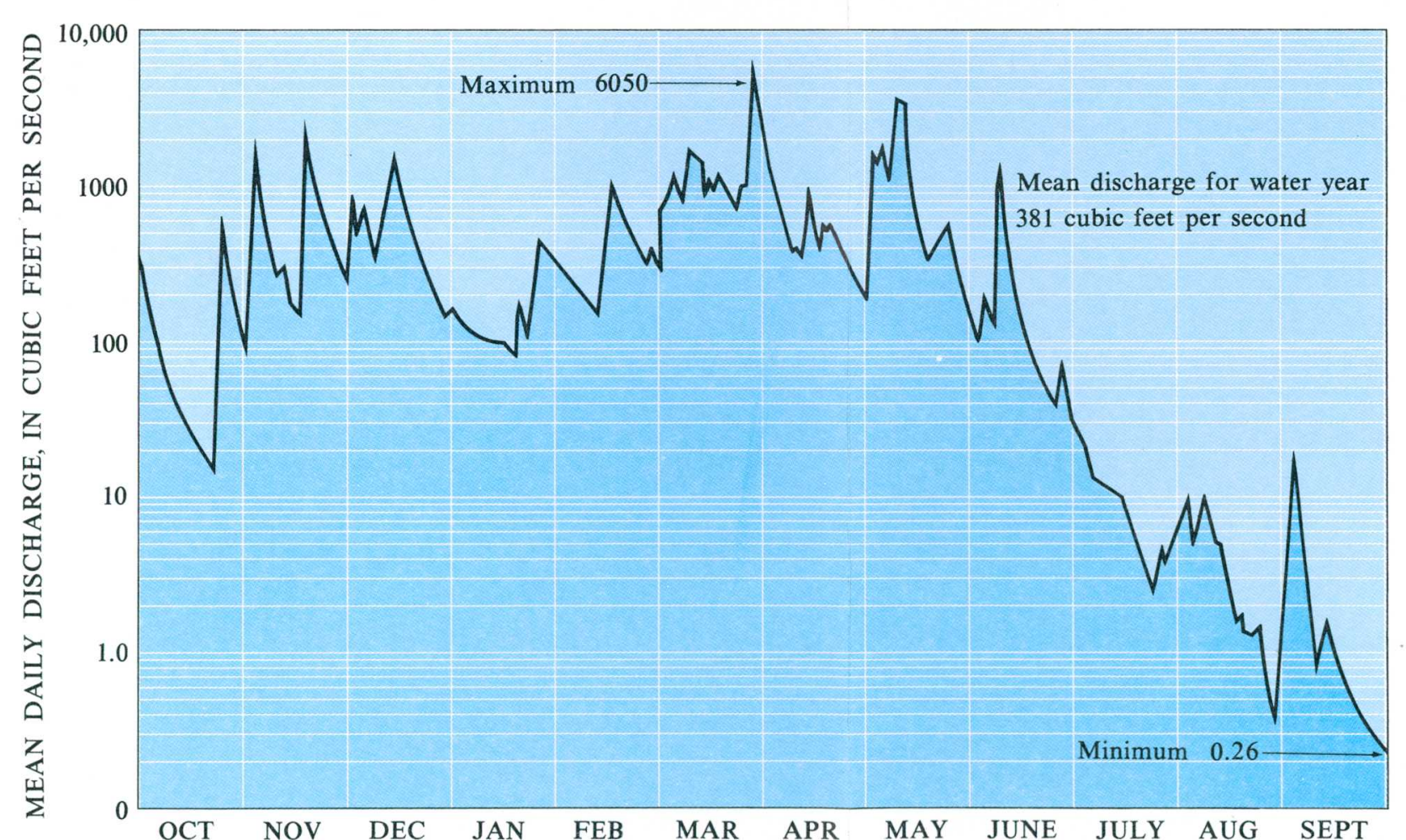

Figure 4.2-3 Mean daily discharge for Big Piney Creek near Doner (site 27), October 1977 to September 1978. 


\title{
4.0 STREAMFLOW--Continued \\ 4.3 Low Flow
}

\section{Ground Water does not Sustain Streamflow in Area 42}

\author{
Streams draining areas less than 100 square miles usually go dry every year \\ and those draining less than 200 square miles go dry every 10 years on \\ the average.
}

\begin{abstract}
Discharge from Pennsylvanian rocks to streams during periods of no rainfall is not sufficient to maintain flow in many streams in Area 42. Streams draining areas of less than 100 square miles usually go dry during the summer.
\end{abstract}

An important flow statistic is the 7-day, 10-year low flow (the lowest 7 consecutive days of flow in a 10 year period). Several water quality standards for the State of Arkansas are based on the 7-day, 10-year low flows. Seven-day, 10-year low flows are shown for 33 sites in figure 4.3-1. For partial-record gaging stations, the 7-day, 10-year low flows were estimated (Hines, 1975). Statistical low flows at continuousrecord gaging stations are given in table 4.3-1. Based on information from table 4.3-1 and from the report by Hines (1975), 7-day, 10-year low flows are zero for areas of less than 200 square miles. 


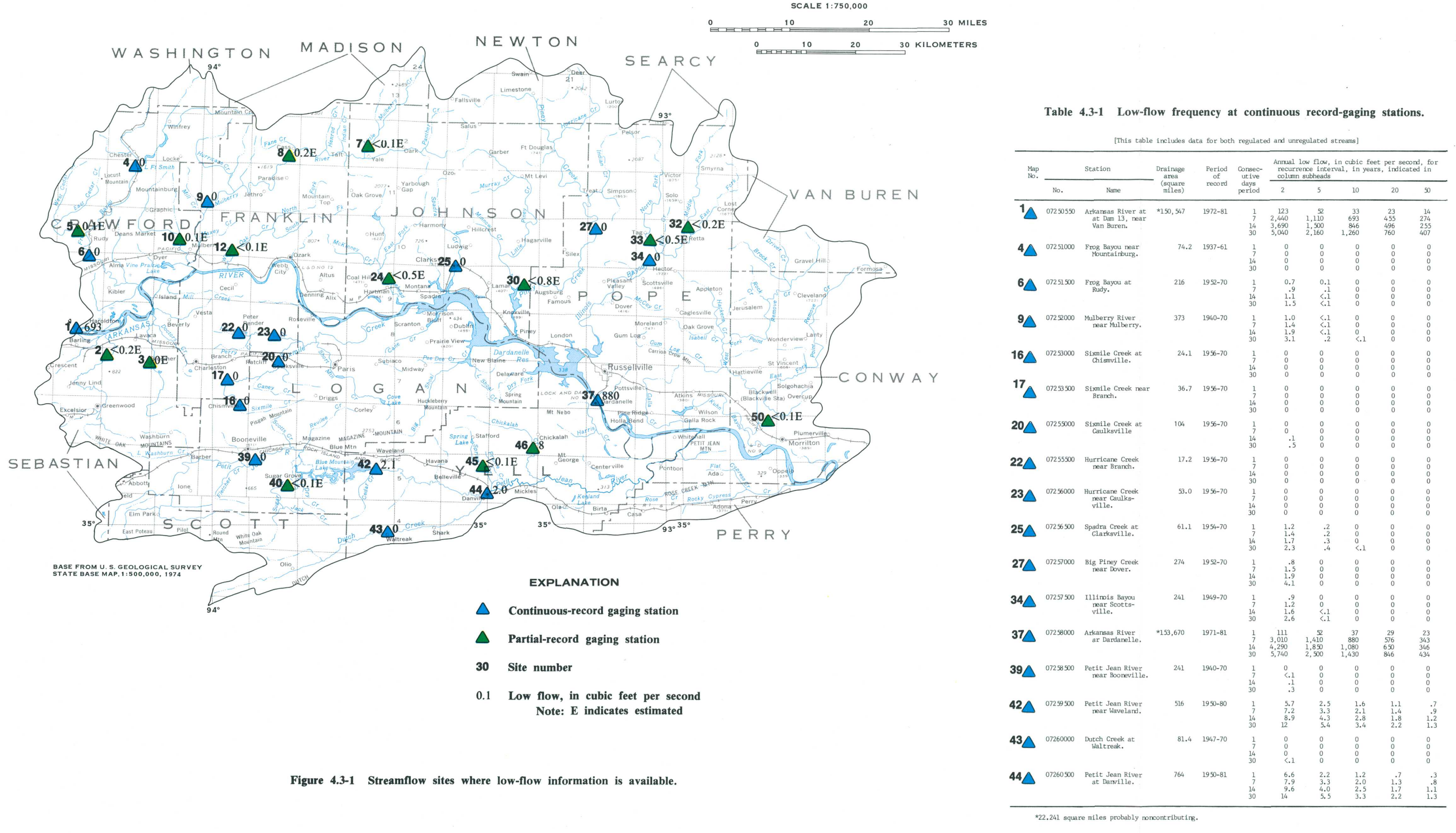




\title{
4.0 STREAMFLOW--Continued \\ 4.4 Flood Frequency
}

\section{Flood Peak and Frequency Data Available at 15 Sites}

\author{
Techniques are available to estimate flood peaks for selected recurrence intervals \\ at gaged and ungaged sites for drainage areas from 0.1 to 3,000 square miles.
}

Flood peaks can be related to basin and climate characteristics. Basin characteristics include area, elevation, slope, soil type, geology, land use, drainage pattern and cultural influences. Modification of these characteristics by an activity such as mining may alter flooding characteristics of a basin.

Where modification of basin characteristics may be anticipated, a knowledge of flood frequencies and peaks is desirable. Flood frequencies are expressed as peak discharges in cubic feet per second at selected recurrence intervals, usually $2,5,10,25$, and 50 years. Flood frequencies for 15 continuous and partial-record gaging stations (fig. 4.4-1) are given in table 4.4-1. Flood frequencies were computed at those sites where sufficient data were available. However, flood-frequency information is often needed where sufficient data for computing flood frequency are not available. Techniques for estimating peaks and frequencies of floods at gaged and ungaged sites throughout Arkansas have been developed by Patterson (1971). The techniques involved the development of a series of regression equations for recurrence intervals of $2,5,10,25$, and 50 years. The basic equation (model) applicable to the mountainous areas of Arkansas, including Area 42, is

$$
\mathrm{Y}=\mathrm{aA}^{\mathrm{b}_{1}} \mathrm{~S}_{2} \mathrm{E}^{\mathrm{b}_{3}} \mathrm{P}^{\mathrm{b}}
$$

where $\mathrm{Y}$ is the peak discharge in cubic feet per second $\left(\mathrm{ft}^{3} / \mathrm{s}\right), \mathrm{a}, \mathrm{b}_{1}, \mathrm{~b}_{2}, \mathrm{~b}_{3}$, and $\mathrm{b}_{4}$ are constants, $\mathrm{A}$ is the basin drainage area in square miles, $S$ is the main channel slope in feet per mile, $E$ is the mean basin elevation in feet above sea level, and $P$ is the mean annual precipitation in inches minus 30 . Equations derived for each of the selected recurrence intervals are given in table 4.4-2. Mean basin elevation (E) and mean annual precipitation $(P)$ can be eliminated without the loss of significant accuracy as shown by the standard error of estimate.

An application of the equation to determine the 50-year flood for a site is as follows: a basin has a drainage area (A) of 225 square miles, a main channel slope (S) of 6.02 feet per mile, a mean basin elevation (E) of 740 feet above mean sea level, and a mean annual precipitation (P) of 44 inches. The peak discharge of the 50 -year flood is computed by using equation $5_{\mathrm{a}}$ as:

$$
\mathrm{Q}_{50}=21.9(225)^{0.62}(6.02)^{0.33}(740)^{0.31}(44-30)^{0.45}=28,900 \mathrm{ft}^{3} / \mathrm{s} \text {. }
$$

Eliminating mean elevation (E) and mean annual precipitation $(\mathrm{P})$ and using equation $5_{\mathrm{c}}$ results in:

$$
\mathrm{Q}_{50}=164(225)^{0.75}(6.02)^{0.63}=29,500 \mathrm{ft}^{3} / \mathrm{s} \text {. }
$$

The equations are applicable to drainage areas of 0.1 to 3,000 square miles in which streams have virtually no regulation by dams or ponds. However, equations 4 and 5, used for recurrence intervals of 25 and 50 years are not applicable to drainage areas of less than 25 square miles. A method for estimating magnitudes of floods in small basins for 25 and 50 year recurrence intervals was also developed by Patterson (1971).

"Values of $\mathrm{Q}_{25} / \mathrm{Q}_{10}$ and $\mathrm{Q}_{50} / \mathrm{Q}_{10}$ for the longterm stations were related to basin parameters and a reasonably good correlation was obtained by using main-channel slope as an independent variable. Drainage-area size did not prove to be significant for areas less than about 500 square miles, and probably no great error will result in using the long-term gaging-station relation for small-area streams.

Peak flows for recurrence intervals of 25 and 50 years can be estimated by first computing the magnitude of the 10-year flood and then multiplying by the appropriate value from relation curves in figure 4.4-2."

For example, to compute the 50-year flood for a site on a basin that has a drainage area of less than 25 square miles and a main channel slope of 20 feet per mile, where the 10-year flood, from equation 3 , is $3,000 \mathrm{ft}^{3} / \mathrm{s}$, using the $\mathrm{Q}_{50} / \mathrm{Q}_{10}$ ratio found in figure 4.4-2 of 1.66 , the result would be

$$
\mathrm{Q}_{50}=1.66 \times 3,000=5,000 \mathrm{ft}^{3} / \mathrm{s} \text {. }
$$




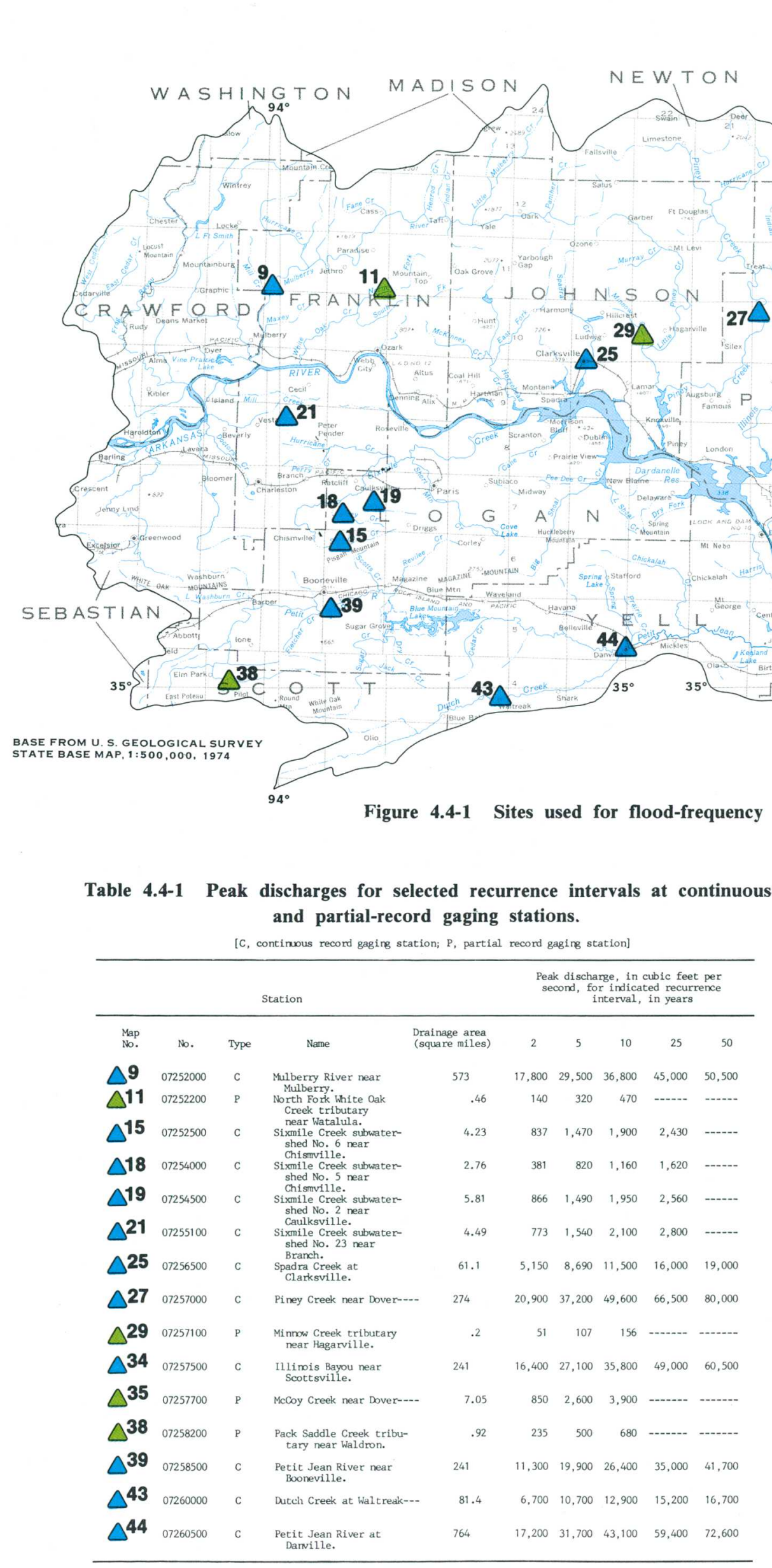

EXPLANATION

$\triangle$ Continuous-record gaging station

$\triangle$ Partial record gaging station

$27 \quad$ Site number
Table 4.4-2 Summary of regression equations.

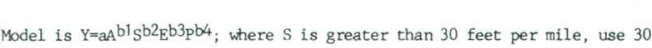

\begin{tabular}{|c|c|c|c|c|c|c|c|c|}
\hline uation & 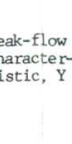 & 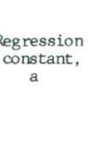 & 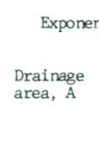 & 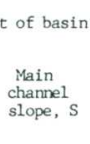 & 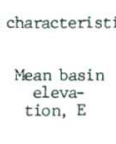 & ic. & 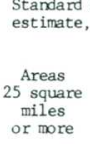 & 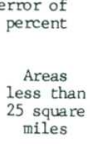 \\
\hline $\begin{array}{l}\text { 1(a) } \\
\text { (b) }\end{array}$ & $Q_{2}$ & $\begin{array}{l}4.99 \\
58.1\end{array}$ & $\begin{array}{l}0.72 \\
.77\end{array}$ & $\begin{array}{l}0.32 \\
.46\end{array}$ & 0.20 & 0.59 & $\begin{array}{l}25 \\
30\end{array}$ & $\begin{array}{l}46 \\
45 \\
45\end{array}$ \\
\hline (c) & 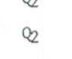 & 276 & .68 & & -1 & & 41 & 50 \\
\hline 2(a) & Qs & 11.8 & .72 & .35 & .21 & .43 & 22 & 40 \\
\hline $\begin{array}{l}\text { (b) } \\
\text { (c) }\end{array}$ & 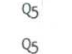 & $\begin{array}{l}91.8 \\
498\end{array}$ & . .68 & .50 & ) & 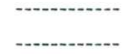 & ${ }_{40}^{26}$ & 36 \\
\hline 3(a) & $Q_{10}$ & 17.2 & .73 & .37 & .21 & .36 & 22 & 40 \\
\hline (b) & $Q_{10}$ & 112 & .78 & .52 & & $\cdots$ & 26 & \\
\hline (c) & 910 & 653 & .68 & $\cdots$ & $\ldots$ & .... & 40 & 40 \\
\hline$x_{4}(a)$ & Qes & 10.8 & .62 & .29 & .36 & .55 & 23 & \\
\hline (b) & Ces & 65.6 & .69 & .45 & .22 & & ${ }^{24}$ & \\
\hline (c) & Q25 & 117 & .77 & .63 & - & - & 26 & - \\
\hline (d) & Ces & 2,680 & .48 & 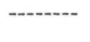 & & & ${ }^{40}$ & \\
\hline${ }^{45(2)}$ & 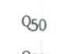 & 21.9 & .62 & .33 & .31 & .45 & 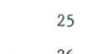 & 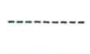 \\
\hline (2) & & & .68 & .46 & .20 & $\cdots$ & 26 & \\
\hline (c) & $\begin{array}{l}0.00 \\
0.50\end{array}$ & $\begin{array}{r}164 \\
3.620\end{array}$ & .75 & .63 & 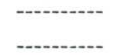 & 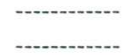 & 年 & \\
\hline & & & & & & & & \\
\hline
\end{tabular}

Modifed from Patterson, 192

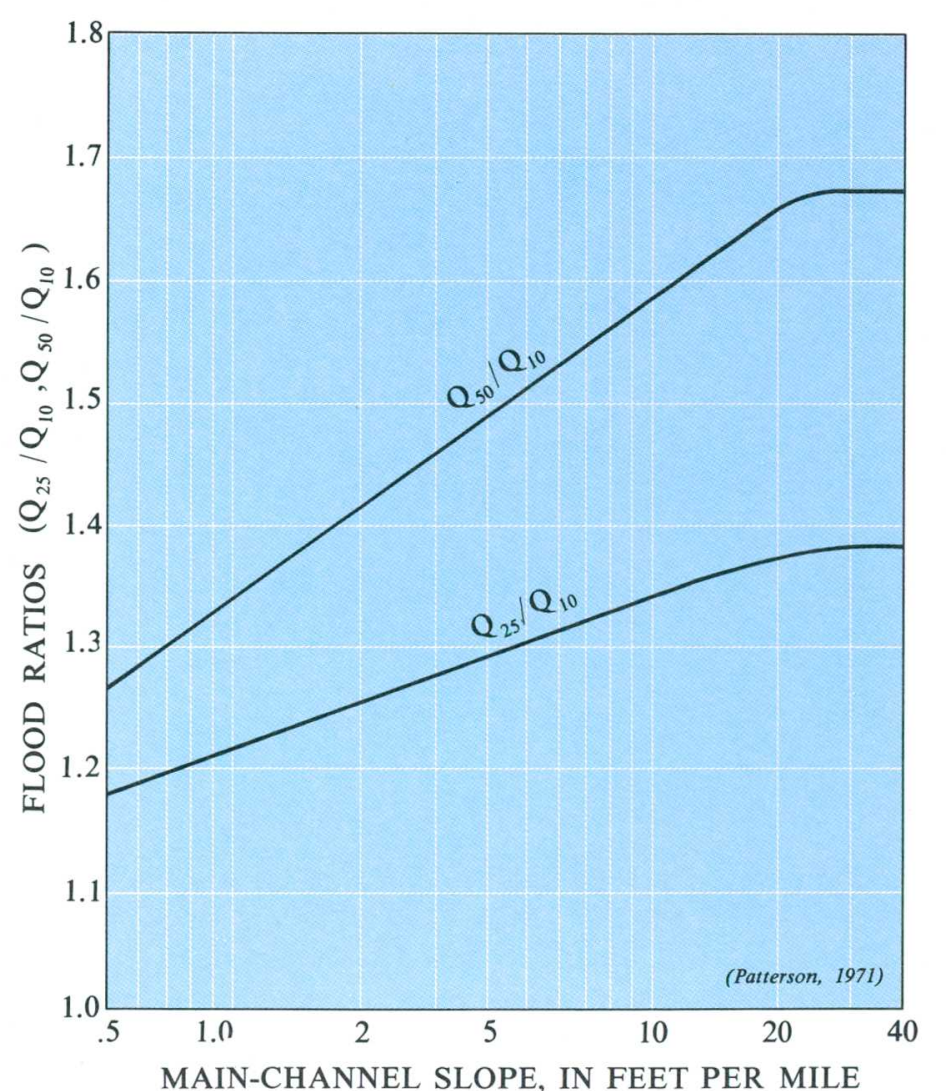

Figure 4.4-2 Relation between flood ratios and main-channel slope.
4.0 STRE A MFLOW--Continued 4.4 Flood Frequency 


\subsection{STREAMFLOW--Continued \\ 4.5 Duration of Flow}

\section{Streamflow is Poorly Sustained}

\section{Streamflow is mainly from direct surface runoff, with little contribution from ground water.}

Differences in streamflow rates are illustrated by flow-duration curves which indicate the relative amounts of stream-flow derived from surface runoff and ground-water discharge. The component of streamflow derived from ground-water discharge, termed "base flow," generally sustains streamflow during dry periods. Curves for three stations in Area 42 (fig. 4.5-1) are shown in figure 4.5-2. Duration curves, based on the period of record at a site, show the percentage of time that a specified discharge was equaled or exceeded.

Duration curves that have flat slopes at lower ends indicate that streamflow is sustained by base flow. A steep slope throughout denotes highly variable streamflow that is mainly from surface runoff. Duration curves for all streams in the area have steep slopes, indicating negligible base flow. 


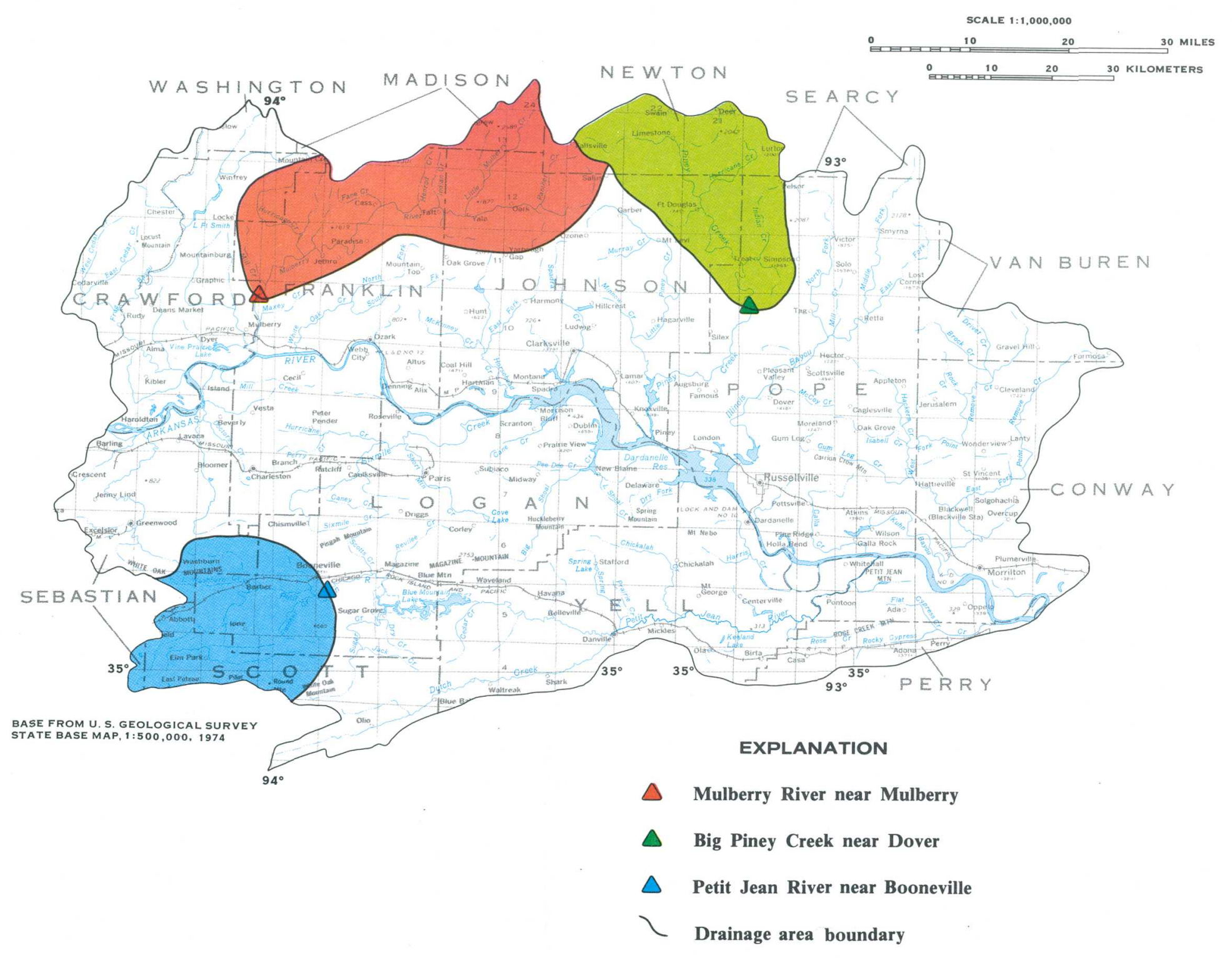

Figure 4.5-1 Location of gaging stations used for flow-duration curves.

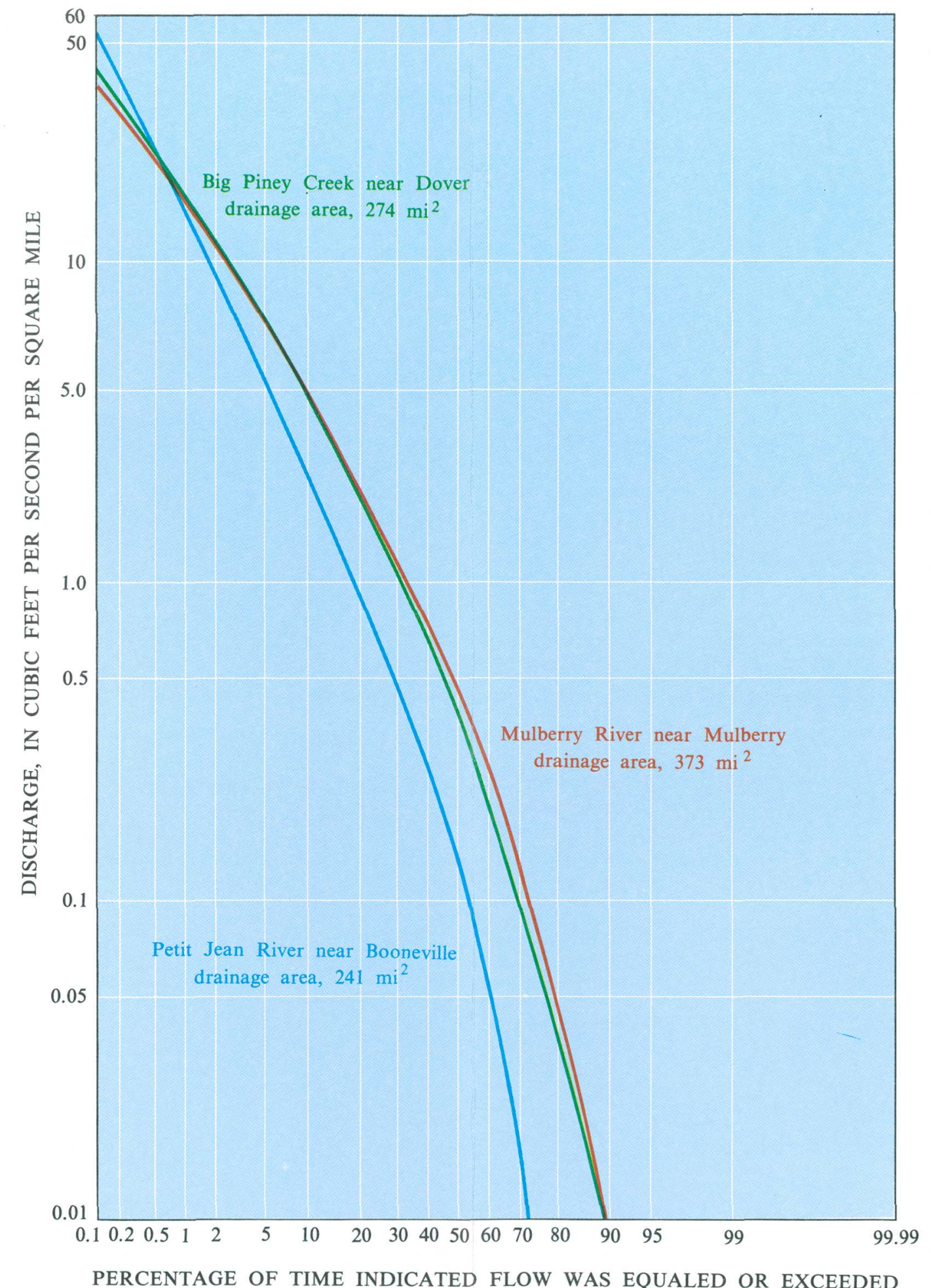

Figure 4.5-2 Flow-duration curves. 


\title{
5.0 SURFACE-WATER QUALITY \\ 5.1 Surface-Water-Quality Data Network
}

\section{Water-Quality Data Network Includes 22 Active and Inactive Sites}

\author{
During 1981 there were eight active water-quality sites, five operated by the \\ Arkansas Department of Pollution Control and Ecology and three by the \\ U.S. Geological Survey.
}

Water quality is generally expressed in terms of physical, chemical or biological characteristics. However, the term "quality" must be defined in terms of the usability of the water. For example, water unsuitable for drinking may be adequate for use in mining operations.

Water-quality information for Area 42 is available from 22 sites shown in figure 5.1-1. Information about the sites shown on the map is in table 5.1-1. During 1981 there were eight active water-quality sites, five operated by the Arkansas Department of Pollution Control and Ecology and three by the U.S. Geological Survey. Data from active sites are published annually in "Water Resources Data for
Arkansas" and are available from the U.S. Geological Survey, Room 2301 Federal Office Building, Little Rock, Arkansas 72201-3287. These data are also available from computer storage through the U.S. Geological Survey's National Water Data Exchange (NAWDEX) and the U.S. Environmental Protection Agency's national water-quality data base called STORET.

No water-quality data sites are located on small streams draining coalmine areas, hence most data presented in subsequent sections do not reflect the impacts of mining. For this reason, the information presented will be very general. 


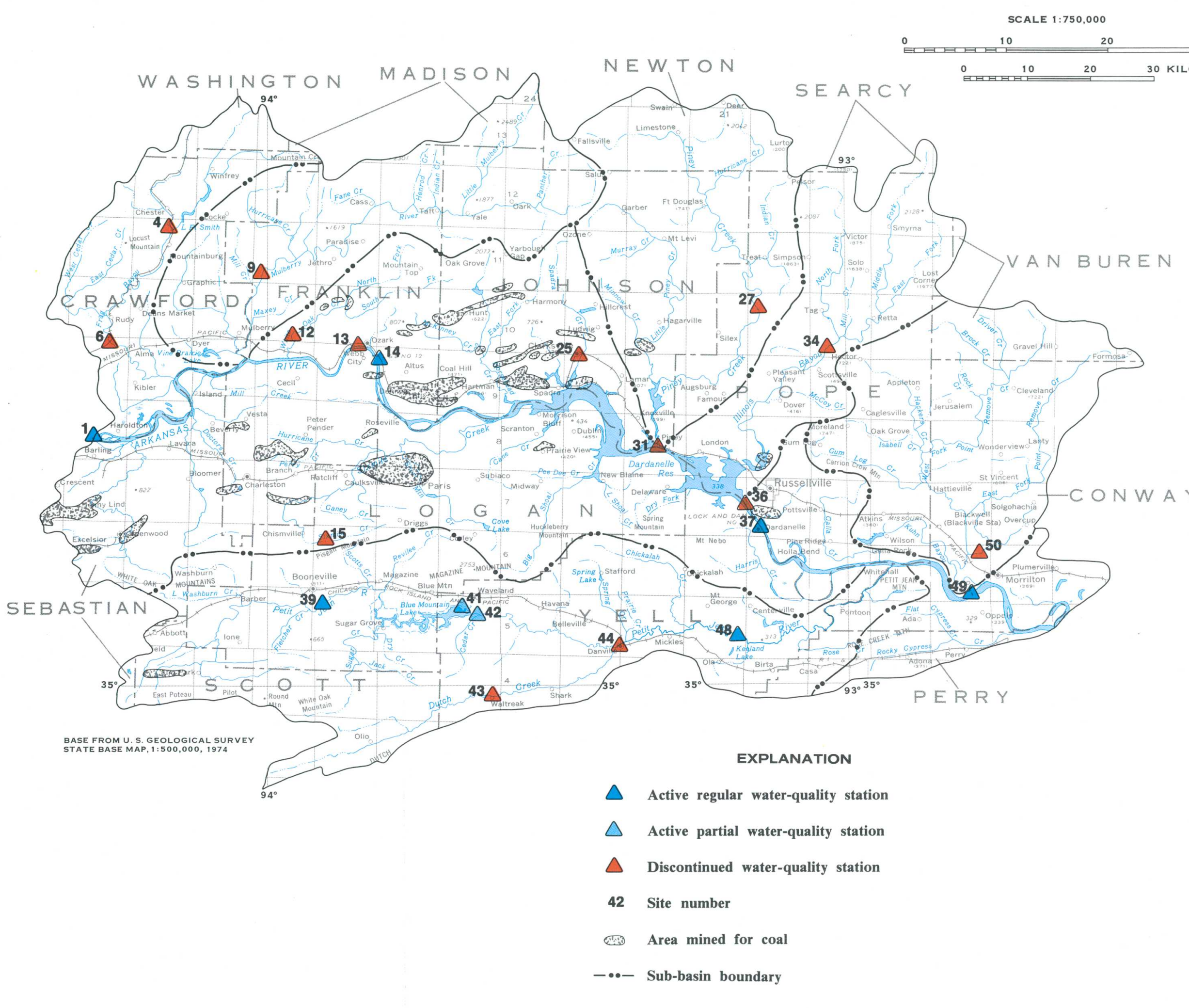

Figure 5.1-1 Surface-water-quality data network.

Table 5.1-1 Station descriptions for surface-water-quality data network.

Type of station: A, Active regular water quality station; D, Discontimued water-quality

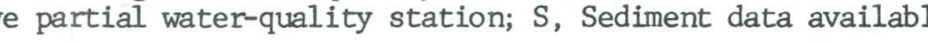

\begin{tabular}{|c|c|c|c|c|c|c|c|}
\hline \multirow[b]{2}{*}{$\begin{array}{l}\text { Map } \\
\text { No. }\end{array}$} & \multicolumn{2}{|r|}{ Station } & \multicolumn{2}{|c|}{ Location } & \multirow{2}{*}{$\begin{array}{c}\text { Drainage } \\
\text { area } \\
\text { (square } \\
\text { miles) }\end{array}$} & \multirow{2}{*}{$\begin{array}{l}\text { Period } \\
\text { of } \\
\text { record }\end{array}$} & \multirow{2}{*}{$\begin{array}{l}\text { Type } \\
\text { of } \\
\text { sta- } \\
\text { tion }\end{array}$} \\
\hline & №. & Name & $\frac{\text { Latitude }}{0.1 "}$ & $\frac{\text { Longitude }}{\circ, 1 "}$ & & & \\
\hline$\Delta^{1}$ & 07250550 & Arkan & 352056 & 941754 & 105,547 & 1927- & $A, S$ \\
\hline$\triangle^{4}$ & 07251000 & $\begin{array}{l}\text { No. } 13 \text { near Ve } \\
\text { Frog Bayou near } \\
\text { Moutainbura }\end{array}$ & 353940 & 940910 & 74.2 & $1947-59$ & D \\
\hline$\Delta^{6}$ & 07251500 & $\begin{array}{l}\text { Mountaininburg. } \\
\text { Frog Bayou at Rudy----- }\end{array}$ & 353132 & $94 \quad 16 \quad 18$ & 216 & $1952-63$ & D \\
\hline$\triangle^{9}$ & 07252000 & Mulberry River near & 353437 & 940055 & 573 & $1947-63$ & D \\
\hline$\Delta^{12}$ & 07252300 & $\begin{array}{l}\text { Mulberry. } \\
\text { White Oak Creek near } \\
\text { Ozank. }\end{array}$ & 353024 & 935646 & 75 & 1959 & D \\
\hline$\triangle^{13}$ & 07252400 & Arkansas River at & $\begin{array}{lll}35 & 29 & 02\end{array}$ & 934956 & 151,797 & $1948-66$ & $D, S$ \\
\hline$\Delta^{14^{*}}$ & 07252406 & $\begin{array}{l}\text { Arkanks. River at } \\
\text { Azark Dive at } 0 \text { zam }\end{array}$ & 352821 & 934846 & 151,801 & 1962- & $A, S$ \\
\hline$\triangle^{15}$ & 07252500 & $\begin{array}{l}\text { Ozark Dam, at Ozark } \\
\text { Sixmile Creek subwater- } \\
\text { shed No. } 6 \text { near } \\
\text { Chismvilie. }\end{array}$ & $3512 \quad 30$ & $93 \quad 5255$ & 4.23 & $1958-61$ & $D, S$ \\
\hline$\Delta^{25}$ & 07256500 & $\begin{array}{l}\text { Spadra Creek at } \\
\text { clarksille. }\end{array}$ & 352806 & 932746 & 61.1 & $1953-63$ & D \\
\hline$\Delta^{27}$ & 07257000 & $\begin{array}{l}\text { Clarksville. } \\
\text { Big Piney Creek near }\end{array}$ & 353258 & 930930 & 274 & $1953-73$ & D \\
\hline$\triangle^{31}$ & 07257250 & $\begin{array}{l}\text { Bover. } \\
\text { Big Piney Creek at }\end{array}$ & 352046 & 931941 & 537 & 1949 & D \\
\hline$\triangle^{34}$ & 07257500 & $\begin{array}{l}\text { Piney. } \\
\text { IIlinois Bayou near } \\
\text { Scott cyilie }\end{array}$ & 352758 & 930228 & 241 & $1948-72$ & D \\
\hline$\Delta^{36}$ & 07257995 & $\begin{array}{l}\text { Scottsville. } \\
\text { Dardanelle Reservoir }\end{array}$ & 351450 & $\begin{array}{lll}93 & 10\end{array}$ & 153,666 & $1966-67$ & D \\
\hline$\Delta^{37^{*}}$ & 07258000 & $\begin{array}{l}\text { at Dardanelle. } \\
\text { Arkansas River at }\end{array}$ & $\begin{array}{lll}35 & 13 & 34\end{array}$ & $\begin{array}{l}93 \quad 0858 \\
\end{array}$ & 153,670 & 1948- & $\mathrm{A}, \mathrm{S}$ \\
\hline$\triangle^{39^{*}}$ & 07258500 & $\begin{array}{l}\text { Darranelle. } \\
\text { Petit Jean River near }\end{array}$ & 350625 & 935525 & 241 & 1974- & A \\
\hline$\Delta^{41}$ & 07259000 & Blue Mountain Lake & 350606 & $93 \quad 3902$ & 488 & 1979- & $P$ \\
\hline$\Delta^{42}$ & 07259500 & $\begin{array}{l}\text { near waveland. } \\
\text { Petit Jean River } \\
\text { near Waveland. }\end{array}$ & 350617 & 933753 & 516 & 1975- & $\mathrm{P}$ \\
\hline$\Delta^{43}$ & 07260000 & Dutch $\mathrm{C}$ & 345915 & 933645 & 81.4 & $1948-60$ & D \\
\hline$\triangle^{44}$ & 07260500 & $\begin{array}{l}\text { Waltreak. } \\
\text { Petit Jean River at } \\
\text { Darville. }\end{array}$ & 350333 & 932344 & 764 & $1946-63$ & D \\
\hline$\Delta^{48^{*}}$ & 07260640 & Petit Jean River near & 350435 & $\begin{array}{lll}93 \quad 12 & 10\end{array}$ & 927 & 1974- & A \\
\hline$\Delta^{49^{*}}$ & 07260660 & erer at Dam & 350726 & $9247 \quad 11$ & 154,949 & 1974- & A \\
\hline$\triangle^{50}$ & 07260700 & $\begin{array}{l}\text { No. 9, near Oppe } \\
\text { Point Remove Creek } \\
\text { near Morrilton. }\end{array}$ & 351056 & 924702 & 488 & 1949 & D \\
\hline
\end{tabular}

*Station operated by Arkansas Department
of Pollution Control and Ecology. 


\subsection{SURFACE-WATER QUALITY--Continued \\ 5.2 Dissolved Solids and Specific Conductance}

\section{Dissolved-Solids Concentrations of Stream Water are Low}

\section{Mineralization of surface water reflects both nature's and man's activities.}

Dissolved-solids concentration in water is a measure of the minerals that have been dissolved by the water. In general, dissolved solids are derived naturally from minerals in soils and rocks of a basin. Where soils and rocks are well weathered and most of the soluble minerals have been removed by leaching, the dissolved-solids concentrations usually are low. Disturbing land surfaces by such activities as mining, agriculture, logging or road building may expose fresh, unleached soils and rocks resulting in increased dissolved-solids concentrations in stream water. Municipal and industrial wastes also increase dissolved-solids concentrations in receiving streams.

Dissolved-solids concentrations in the Arkansas River are greater than in the tributary streams (fig. 5.2-1, table 5.2-1). The principal sources of dissolved solids in the Arkansas River are from rocks, industrial wastes. and oil-field brines. Most of the wastes and brines enter the river upstream from the area.

Dissolved-solids concentrations in the tributary streams, are less than in the Arkansas River and reflect relatively undisturbed land surfaces and well- weathered rocks and soils. None of the data available reflect impacts of coal mining as no data were collected on the small streams draining the coal areas.

Dissolved-solids concentrations, as shown in table 5.2-1 were determined in the laboratory by evaporating the water and weighing the residue (Skougstad and others, 1979). Another method for determining dissolved solids is to use specific conductance measurements of the water (Hem, 1970). Specific conductance is a measure of the electrical conductivity of the water and is expressed in micromhos per centimeter at $25^{\circ} \mathrm{C}$. Specific conductance is related to the type and concentration of ions in solution and can be used for approximating the dissolved-solids concentrations of the water. Commonly, the concentrations of dissolved solids, in milligrams per liter, is about 65 percent of the specific conductance, in micromhos, (Hem, 1970). This relationship is not constant from stream to stream, and it may vary in the same source with changes in the composition of the water. 


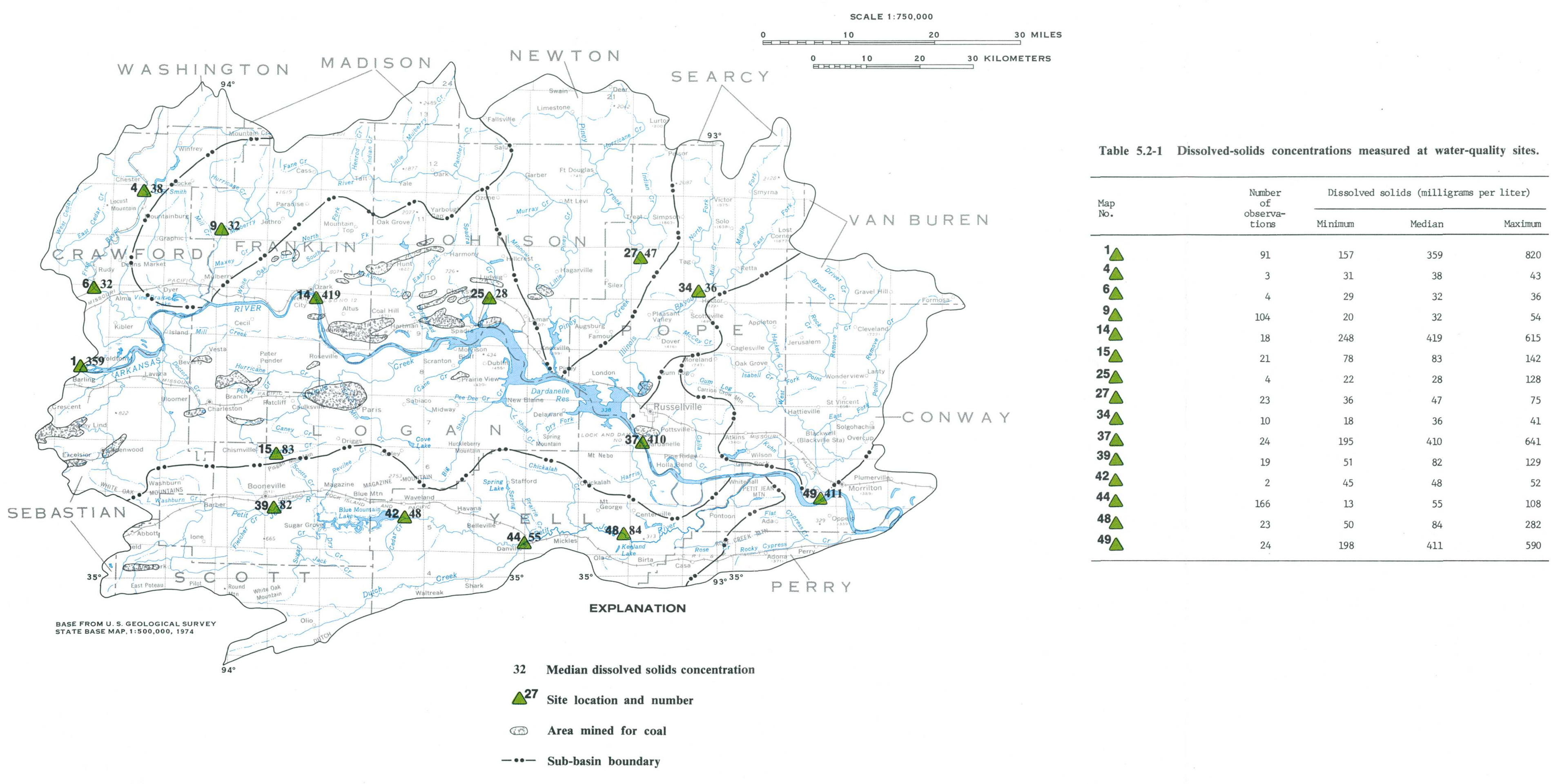

Figure 5.2-1 Water-quality sites where dissolved-solids concentrations were measured. 


\title{
5.0 SURFACE-WATER QUALITY--Continued $5.3 \mathrm{pH}$
}

\section{The pH of Streamflow is Usually Neutral}

\author{
The $\mathrm{pH}$ of water in streams usually ranges from 5.0 to 9.0 units; available \\ data does not indicate that the $\mathrm{pH}$ of streams is lowered by mine drainage.
}

A $\mathrm{pH}$ value of 7.0 represents neutral water. Values less than 7.0 denote acidic water and values greater than 7.0 denote alkaline water. The $\mathrm{pH}$ of water exerts a strong influence on the suitability of water for industrial, municipal, and recreation purposes. Prolonged extreme $\mathrm{pH}$ levels ( $\mathrm{pH}$ less than 5.5 and greater than 9.0 units) can significantly affect aquatic productivity, corrosivity, and the toxicity, mobility, and solubility of many chemical compounds.

In unmined areas, the $\mathrm{pH}$ of water is primarily controlled by the presence of dissolved carbon dioxide and the hydrolysis of salts of weak acids and strong bases or both. Sources of these substances generally include rainfall, weathered geologic strata, and decomposition of organic matter in soils. The median of $\mathrm{pH}$ values generally observed in streams draining undisturbed basins is shown in figure 5.3-1. The $\mathrm{pH}$ of water in streams varies widely (5.0-9.0 units), but the median $\mathrm{pH}$ was usually in the near neutral range (6.9-8.0 units) (table 5.3-1). Fluctuation of $\mathrm{pH}$ is generally related to one or more environmental factors such as geology, streamflow, and land use.

During low flow the $\mathrm{pH}$ values in streams approach that of water in aquifers underlying the basin, whereas during high flow the $\mathrm{pH}$ values approach those of overland runoff. $\mathrm{pH}$ values generally decrease with increased streamflow.

The $\mathrm{pH}$ of mine effluents is determined by the chemical character of the spoil. In some areas, weathering of pyrite and other sulfate-bearing minerals results in the production of sulfuric acid. Acidmine drainage may have $\mathrm{pH}$ values that range from 2.0 to 5.0 units. In many areas, calcareous minerals such as siderite, calcite, and ankerite commonly occur in large quantities in spoil. In these areas, acidic mine drainage is rapidly neutralized. 


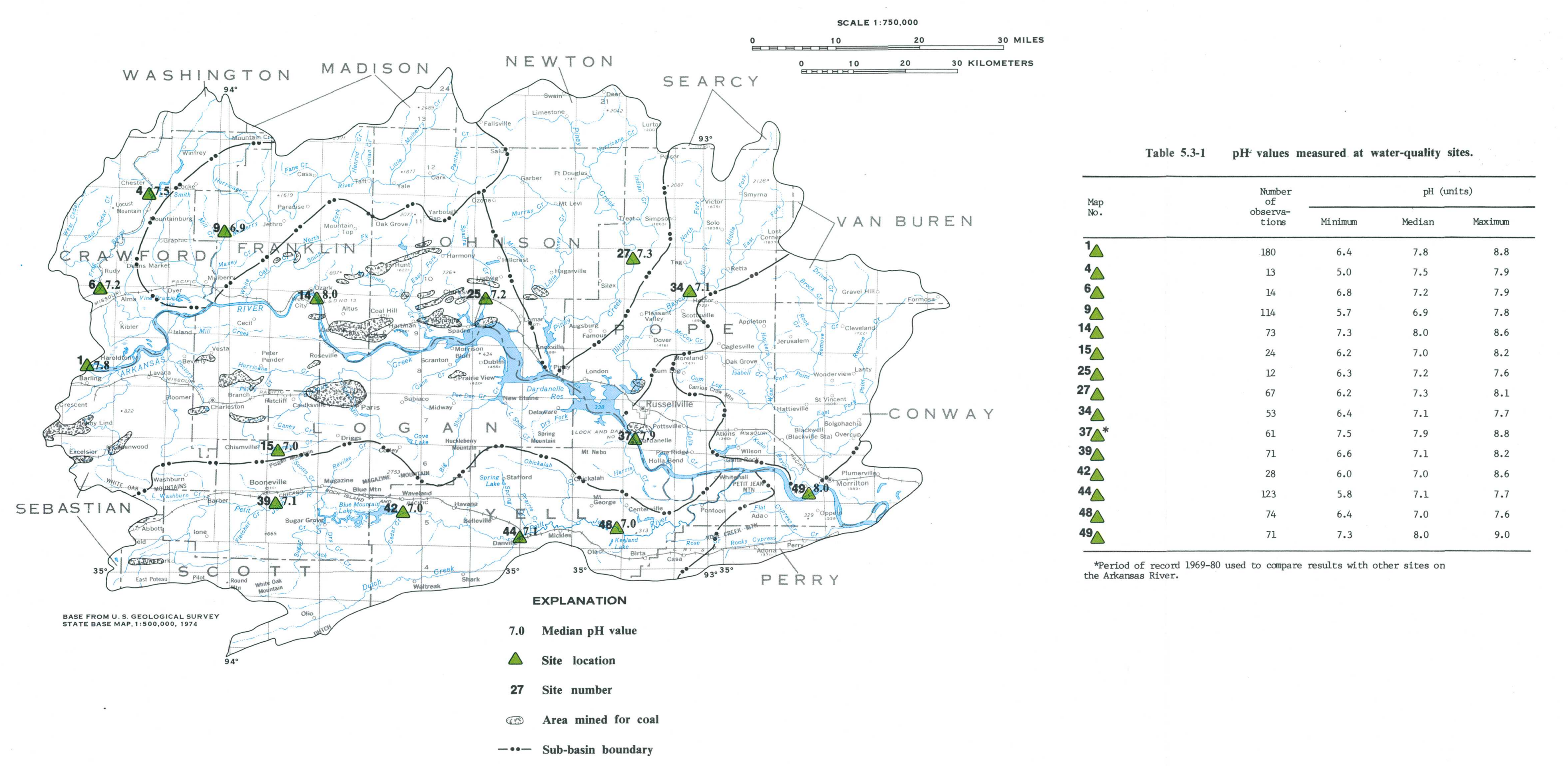

Figure 5.3-1 Water-quality sites where $\mathrm{pH}$ concentrations were measured. 


\subsection{SURFACE-WATER QUALITY--Continued 5.4 Sulfate}

\section{Sulfate Concentrations are Insignificant in Streams of the Area}

\section{Sulfate concentrations range from 0.2 to 110 milligrams per liter with the larger concentrations occurring in the Arkansas River and smaller concentrations in the tributaries.}

Sulfur, although not a major constituent in the Earth's outer crust, is widely distributed in rocks, generally as metallic sulfides and sulfate-bearing materials. When exposed to air and water, sulfides are oxidized to yield sulfate ions that are carried off in the water. Metallic sulfides and sulfate-bearing minerals from rocks may be the principal source of sulfates in streams.

Sulfate concentrations are higher in the Arkansas River than in tributary streams. Where the Arkansas River enters the area (fig. 5.4-1), the median sulfate concentration is 44 milligrams per liter $(\mathrm{mg} / \mathrm{L})$. Where the Arkansas River leaves the area the median sulfate concentration is $40 \mathrm{mg} / \mathrm{L}$, indicating that the sulfate concentration has been diluted by tributary streams.

Sulfate concentrations in tributary streams of the Arkansas River range from 0.2 to $72 \mathrm{mg} / \mathrm{L}$ (table 5.4-1). No significant variations in sulfate concentrations in tributary streams are apparent, although much lower concentrations are present in the northwestern part of the study area. The highest concentration of sulfate $(72 \mathrm{mg} / \mathrm{L})$ was in a tributary downstream from a coal-mining area. However, not enough data are available to determine if the high sulfate originated in the mined area. 


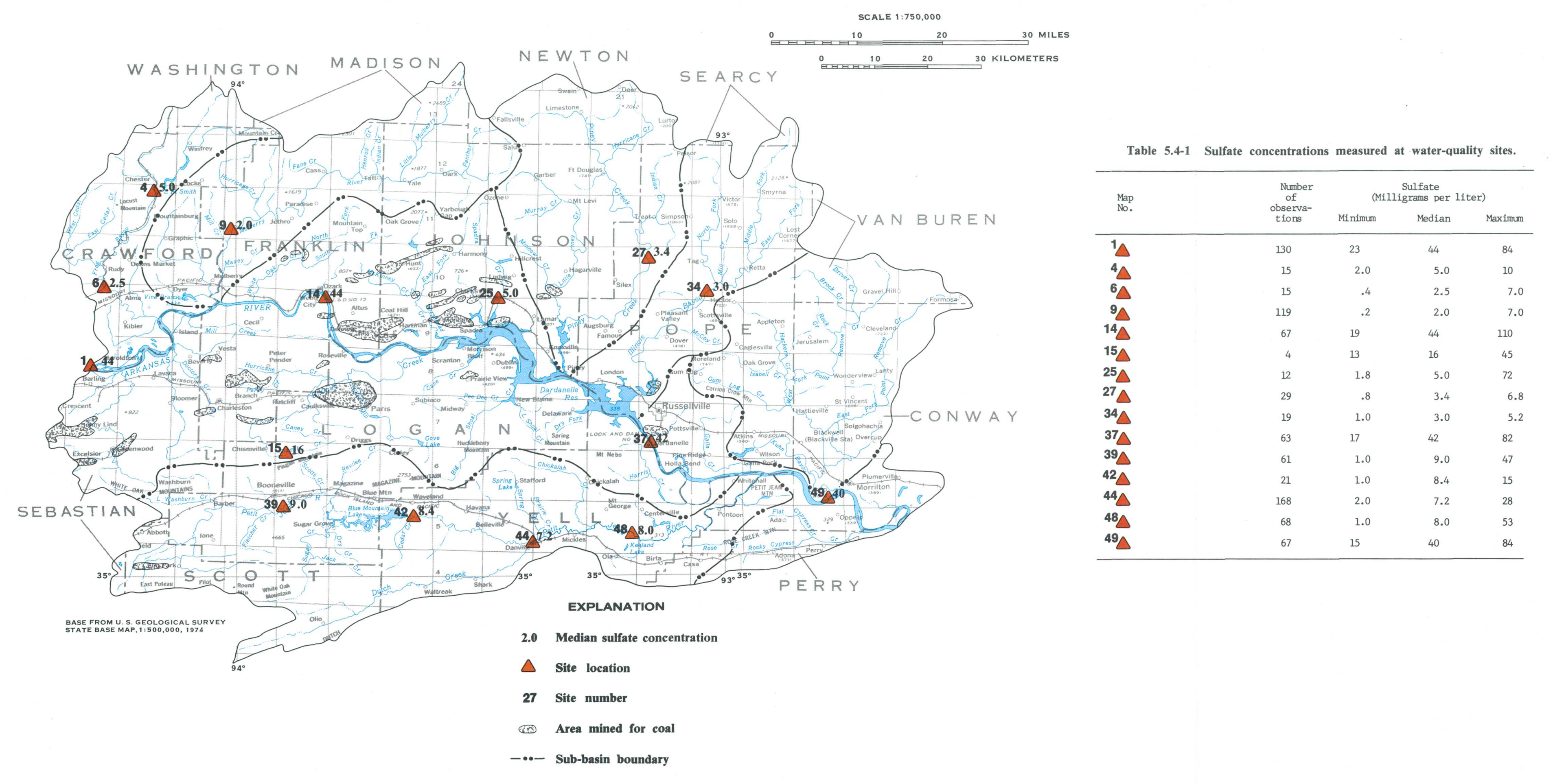

Figure 5.4-1 Water-quality sites where sulfate concentrations were measured. 


\subsection{SURFACE-WATER QUALITY--Continued \\ 5.5 Iron and Manganese}

\section{Iron and Manganese Concentrations Vary with Streamflow and Location}

\section{Although iron and manganese concentrations vary with streamflow and between sites, the concentrations of dissolved and total recoverable iron and manganese in most streams were less than mandatory limits.}

Because excessive concentrations of iron and manganese can limit severely the use of water for public supply, domestic and recreational purposes, most water-supply criteria contain recommended maximum limits for dissolved iron and manganese. For domestic water supplies, the U.S. Environmental Protection Agency (1976) has set a limit of 300 micrograms per liter $(\mu \mathrm{g} / \mathrm{L})$ of dissolved iron and 50 $\mu \mathrm{g} / \mathrm{L}$ of dissolved manganese. The Surface Mining Control and Reclamation Act of 1977 established limits for total recoverable iron and manganese in effluents from mining operations (total recoverable iron and manganese includes both the dissolved and susupended concentrations). The Act specifies 7,000 $\mu \mathrm{g} / \mathrm{L}$ for total recoverable iron and $4,000 \mu \mathrm{g} / \mathrm{L}$ for total recoverable manganese as maximum allowable concentrations in mine effluents.

Iron and manganese concentrations (dissolved and total recoverable) were measured at several sites in Area 42 (fig. 5.5-1). Dissolved iron and manganese concentrations were within limits set for domestic water supplies (tables 5.5-1 and 5.5-2). The maximum dissolved iron and manganese concentrations of $220 \mu \mathrm{g} / \mathrm{L}$ and $40 \mu \mathrm{g} / \mathrm{L}$ respectively, were measured on the Arkansas River (site 1).

The maximum total recoverable iron and manganese in water occurs during high flows because large amounts of suspended iron and manganese are transported with suspended sediment. Maximum concentrations of total recoverable iron in water from the Petit Jean River (sites 39, 42, and 48) exceeded the maximum allowable concentrations for mine effluents. Maximum concentrations at these sites ranges from 13,200 to $19,400 \mu \mathrm{g} / \mathrm{L}$. All maximum total recoverable manganese concentrations were less than the maximum mine effluent concentrations allowed by the Act. 


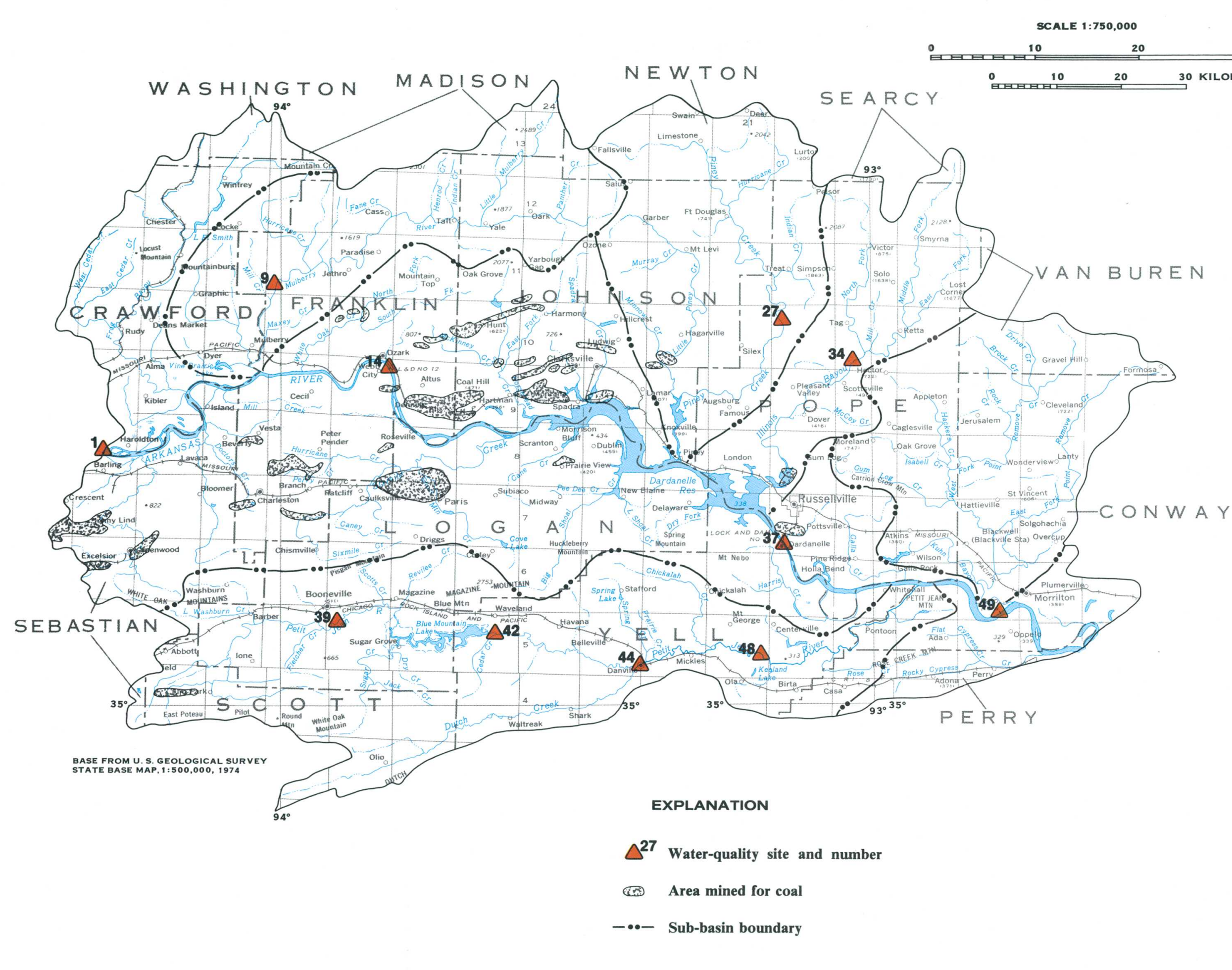

Table 5.5-1 Dissolved and total-recoverable iron concentrations measured at water-quality sites.

\begin{tabular}{|c|c|c|c|c|c|c|c|c|}
\hline \multirow{2}{*}{$\begin{array}{c}\text { Map } \\
\text { No. } \\
\triangle^{1}\end{array}$} & \multirow{2}{*}{$\begin{array}{c}\begin{array}{c}\text { Number of } \\
\text { Observations }\end{array} \\
29\end{array}$} & \multicolumn{3}{|c|}{ 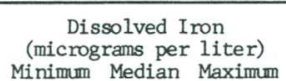 } & \multirow{2}{*}{$\begin{array}{c}\text { Number of } \\
\text { Observations } \\
29\end{array}$} & \multicolumn{3}{|c|}{$\begin{array}{c}\text { Total Recoverable Iron } \\
\text { (mincrograms per 1iter) } \\
\text { Minimum Median Maximum }\end{array}$} \\
\hline & & 10 & 32 & 220 & & 50 & 864 & 4,100 \\
\hline$\triangle^{9}$ & 33 & 0 & 46 & 190 & -- & -- & -- & -- \\
\hline$\triangle^{14}$ & -- & -- & -- & -- & 60 & 226 & 1,620 & 4,700 \\
\hline$\triangle^{27}$ & 19 & 0 & 36 & 180 & -- & -- & -- & -- \\
\hline$\triangle^{34}$ & 11 & 0 & 33 & 140 & -- & -- & -- & -- \\
\hline$\triangle^{37}$ & -- & -- & -- & -- & 43 & 90 & 1,090 & 4,300 \\
\hline$\triangle^{39}$ & -- & -- & -- & -- & 67 & 200 & 1,590 & 13,200 \\
\hline$\triangle^{42}$ & -- & -- & -- & -- & 19 & 400 & 2,720 & 16,000 \\
\hline$\triangle^{44}$ & 2 & 40 & 45 & 50 & -- & -- & -- & -- \\
\hline$\triangle^{48}$ & -- & -- & -- & -- & 71 & 760 & 3,250 & 19,400 \\
\hline$\triangle^{49}$ & -- & -- & -- & -- & 69 & 120 & 1,280 & 3,800 \\
\hline
\end{tabular}

Figure 5.5-1 Water-quality sites where iron and manganese concentrations were measured.

Table 5.5-2 Dissolved and total-recoverable manganese concentrations measured at water-quality sites.

\begin{tabular}{|c|c|c|c|c|c|c|c|c|}
\hline \multirow{2}{*}{$\begin{array}{c}\text { Map } \\
\text { No. } \\
\triangle^{1}\end{array}$} & \multirow{2}{*}{$\begin{array}{l}\text { Nunber of } \\
\text { Observations } \\
30\end{array}$} & \multicolumn{3}{|c|}{$\begin{array}{c}\text { Dissolved Marganese } \\
\text { (mic cograms per liter) } \\
\text { Mininumum Median Maximum }\end{array}$} & \multirow{2}{*}{$\begin{array}{l}\text { Nunber of } \\
\text { observations } \\
29\end{array}$} & \multicolumn{3}{|c|}{$\begin{array}{l}\text { Total Recoverable Manganese } \\
\text { (micrograns per litere } \\
\text { Minimum Median Maximum }\end{array}$} \\
\hline & & 0 & 7 & 40 & & 0 & 77 & 130 \\
\hline$\triangle^{14}$ & -- & -- & -- & -- & 63 & 10 & 105 & 530 \\
\hline$\triangle^{27}$ & 7 & 0 & 11 & 20 & -- & -- & -- & -- \\
\hline$\triangle^{34}$ & 7 & 0 & 15 & 40 & -- & -- & -- & -- \\
\hline$\triangle^{37}$ & -- & -- & - & -- & 45 & 10 & 93 & 229 \\
\hline$\triangle^{39}$ & -- & -- & -- & -- & 69 & 10 & 231 & 1,500 \\
\hline$\triangle^{42}$ & -- & -- & -- & -- & 19 & 80 & 414 & 1,400 \\
\hline$\triangle^{48}$ & -- & -- & -- & -- & 73 & 22 & 395 & 2,400 \\
\hline$\triangle^{49}$ & -- & -- & -- & -. & 71 & 10 & 104 & 220 \\
\hline
\end{tabular}




\subsection{SURFACE-WATER QUALITY--Continued \\ 5.6 Trace Metals}

\section{Trace-Metal Concentrations Exceeded Desirable Limits in Some Locations}

\section{Maximum cadmium and lead concentrations exceeded EPA recommended limits at the six locations sampled.}

Trace metals occur naturally in soils and rocks. Low concentrations of these metals are common in most waters. Anomalously high concentrations can occur naturally; however, such high concentrations of trace metals generally occur because of waste discharge.

Some trace metals pose a danger to human health; for this reason, the Environmental Protection Agency has recommended that limits be set for drinking water (1977). Limits set by Environmenmental Protection Agency for selected trace metals, in micrograms per liter, are:

$\begin{array}{ll}\text { Arsenic } & 50 \\ \text { Cadmium } & 10 \\ \text { Chromium } & 50\end{array}$

$\begin{array}{lr}\text { Copper } & 1,000 \\ \text { Lead } & 50 \\ \text { Zinc } & 5,000\end{array}$

Trace-metal concentrations have been measured at 6 locations in Area 42 (fig. 5.6-1). Maximum trace-metal concentrations in Area 42 (table 5.6-1) sometimes exceeded the U.S. Environmental Protection Agency recommended limits for drinking water. Specifically, maximum cadmium and lead concentrations exceeded the limits of 10 and 50 micrograms per liter, respectively. However, these concentrations are reported as "total recoverable." Filtering out solid particles likely would reduce the concentration. 


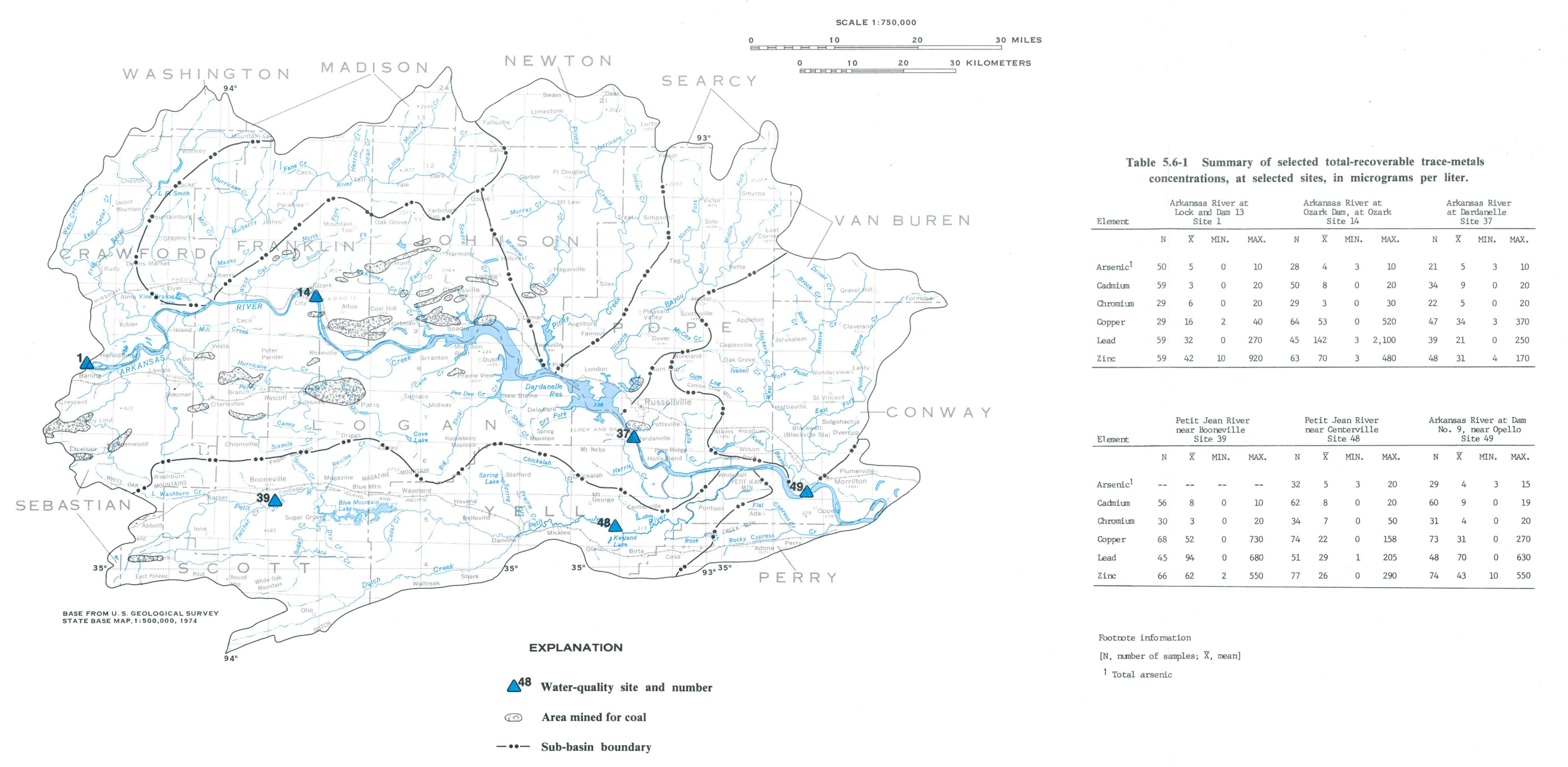

Figure 5.6-1 Water-quality sites where trace-metal concentrations were measured. 


\subsection{SURFACE-WATER QUALITY--Continued 5.7 Sediment}

\section{Average Annual Sediment Yield for Principal Basins is Low}

\section{Sediment yields in principal basins range from 188 to 413 tons per square mile per year; large yields occur where agricultural land use predominates.}

Sediment in streams is the result of erosion of land and the degradation of stream channels or both. Soil characteristics, rainfall intensity, land use, (agricultural, mining, forestry), and slope are the most important factors in overland sediment erosion. The rate of streamflow, slopes, soil types and vegetation will affect the rate of stream-channel erosion.

Sediment yields have been estimated by the U.S. Department of Agriculture. Gross erosion and sediment yield were determined by using a computer program called the Resource Information Data System (RIDS). Sheet erosion was computed by using the Universal Soil Loss Equation for sheet and rill erosion, whereas the direct-volume method was used to obtain streambank, gully, and roadside erosion.
Sediment-yield estimates were made by using the sediment delivery-ratio method which is based primarily on drainage-area size (oral commun., 1981, Jimmy L. Arrington, U.S. Department of Agriculture, Soil Conservation Service).

The average annual sediment yield for the principal basins in Area 42 (fig. 5.7-1) is estimated to be 312 tons per square mile. Estimated sediment yields range from 188 to 413 tons per square mile. The higher sediment yields generally occur in basins where agriculture predominates, and especially where row-crop farming is fairly common. Lower sediment yields occur in basins where land disturbance is minimal. 


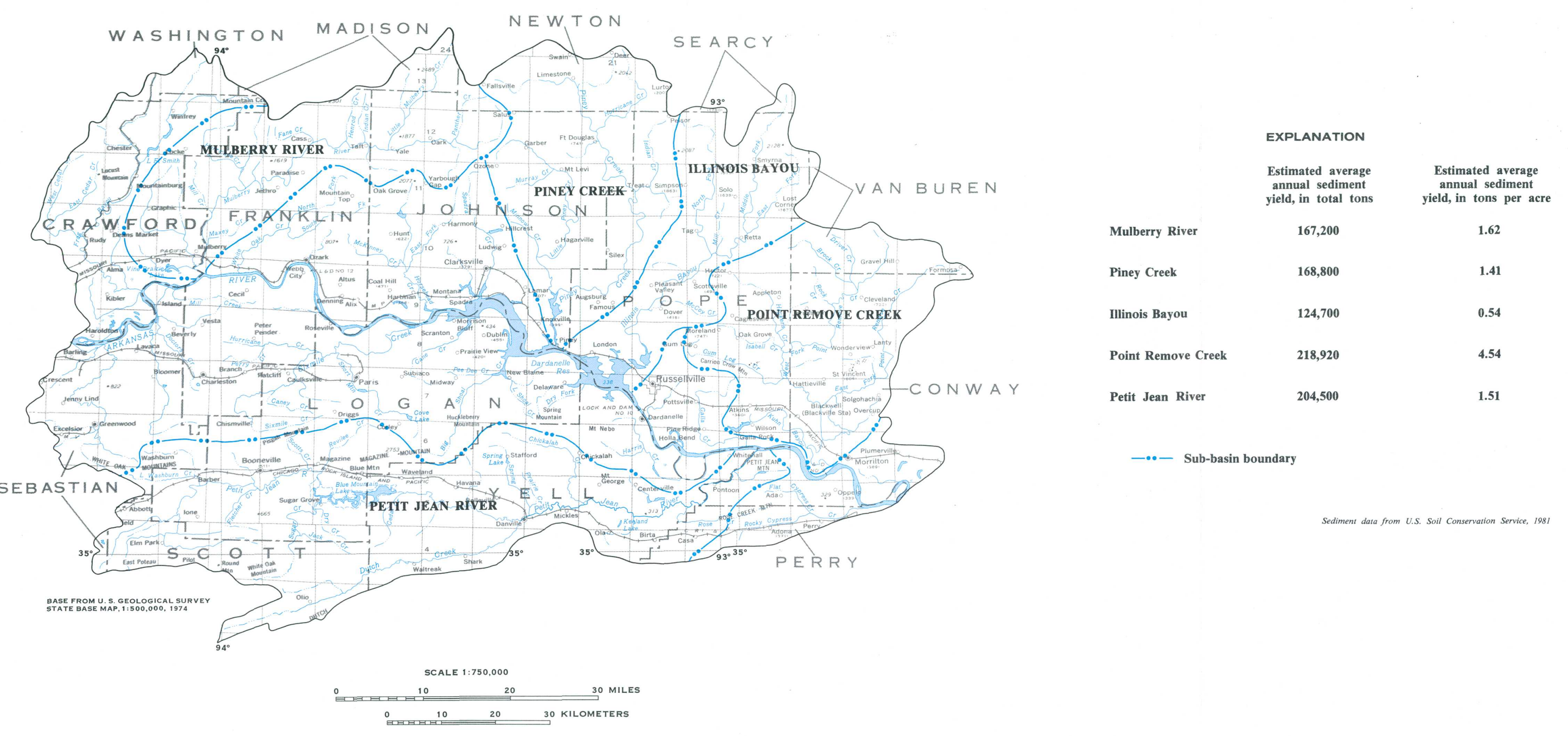

Figure 5.7-1 Average estimated annual sediment yields. 


\author{
5.0 SURFACE-WATER QUALITY--Continued \\ 5.8 Sulfate Concentrations, Specific Conductance, and $\mathrm{pH}$ of Water \\ in Mine Ponds
}

\title{
Sulfate Concentration, Specific Conductance and pH were Determined from Twenty-Two Mine Ponds
}

\author{
Water-quality in mine ponds is variable. Some mines are potential \\ water supply sources.
}

Several mine ponds are located in Area 42 (fig. 5.8-1). Mine ponds were created when mining ceased in an area, and the abandoned site filled with water from precipitation and surface runoff (fig. 5.8-2), and in some places from groundwater infiltration (fig. 5.8-3).

Water samples collected from 22 mine ponds (fig. 5.8-1) were analyzed for sulfate concentration, $\mathrm{pH}$, and specific conductance (table 5.8-1). Sulfate concentrations ranged from 2.9 to 990 milligrams per liter $(\mathrm{mg} / \mathrm{L})$, and averaged $219 \mathrm{mg} / \mathrm{L}$. The average sulfate concentration of acid pH water was $166 \mathrm{mg}$ / $\mathrm{L}$, whereas the average sulfate concentration of alkaline $\mathrm{pH}$ water was $362 \mathrm{mg} / \mathrm{L}$.

Specific-conductance values ranged from 24 to 1,600 micromhos per centimeter at $25^{\circ}$ Celsius $(\mu \mathrm{mhos} / \mathrm{cm})$. The average specific-conductance value was $522 \mu \mathrm{mhos} / \mathrm{cm}$. The average specific-conductance value for acid $\mathrm{pH}$ water was $384 \mu$ mhos/ $\mathrm{cm}$, and the average specific conductance for alkaline $\mathrm{pH}$ water was $890 \mu \mathrm{mhos} / \mathrm{cm}$. 


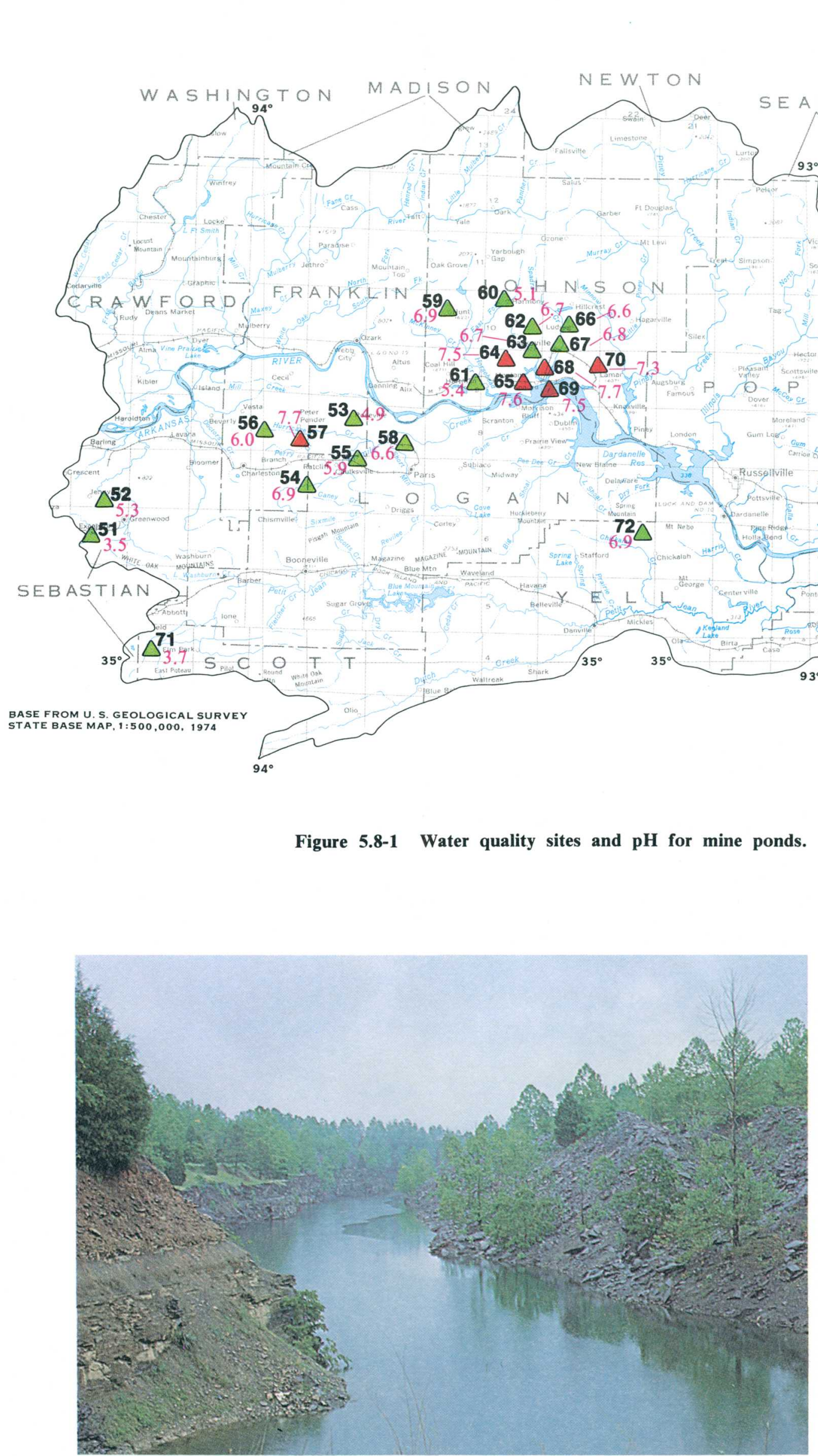

Figure 5.8-2 Mine pond replenished with rainfall and surface-water discharge.

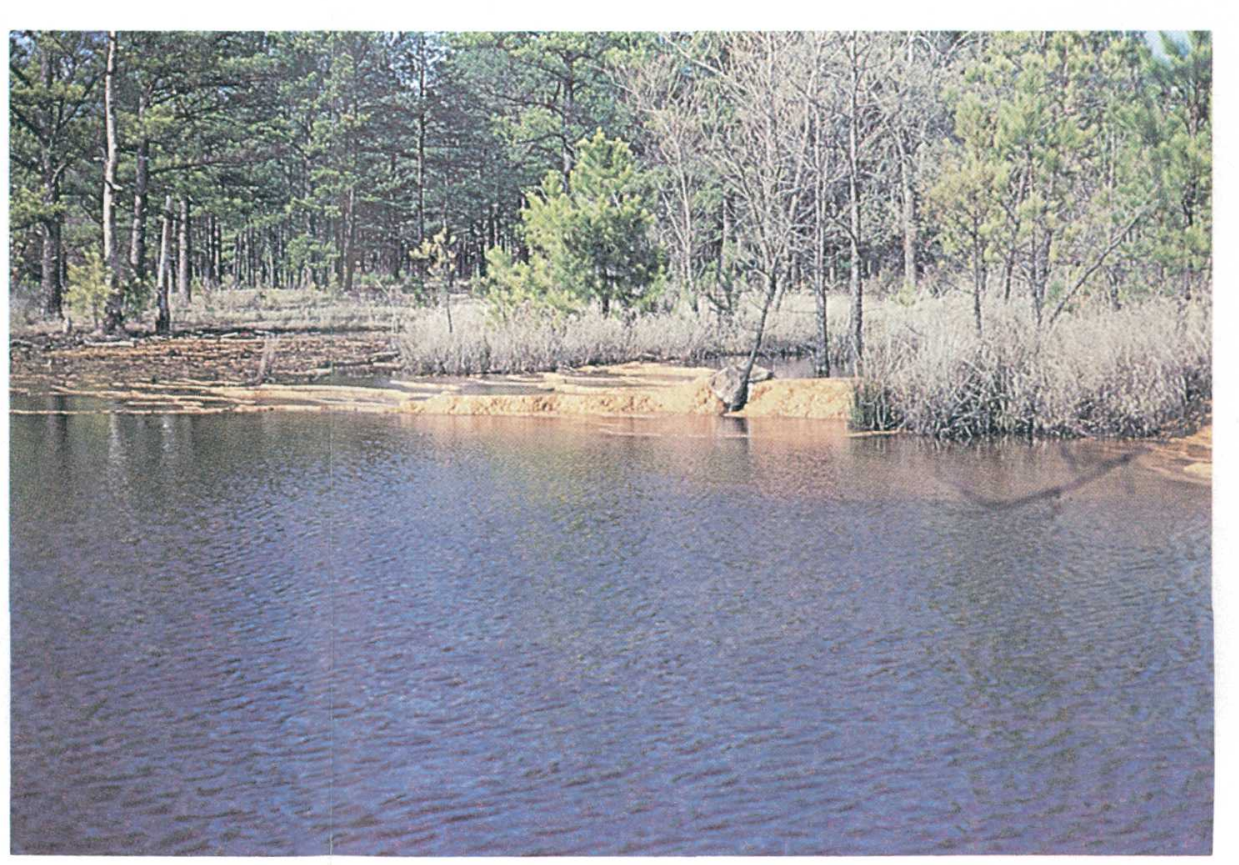

Figure 5.8-3 Mine pond replenished with ground-water discharge.
Table 5.8-1 Concentrations of sulfate and values of specific conductance and $\mathrm{pH}$ of water from mine ponds.

\begin{tabular}{|c|c|c|c|c|c|c|c|}
\hline \multirow{2}{*}{$\begin{array}{l}\begin{array}{l}\text { Site } \\
\text { No. }\end{array} \\
\triangle \triangle^{51}\end{array}$} & \multirow{2}{*}{$\begin{array}{l}\begin{array}{c}\text { Number } \\
\text { of } \\
\text { samples }\end{array} \\
1\end{array}$} & \multicolumn{2}{|c|}{$\begin{array}{l}\text { Sulfate, dis- } \\
\text { solved (milli- } \\
\text { grams per liter) } \\
\text { Maximm Minimm }\end{array}$} & \multicolumn{2}{|c|}{$\begin{array}{l}\text { Specific conductance } \\
\text { (micromhos per cen- } \\
\text { timeter at } 25^{\circ} \mathrm{C} \text { ) } \\
\text { Maximum Minimum }\end{array}$} & \multicolumn{2}{|c|}{$\begin{array}{l}\text { e } \\
\text { Manimits) } \\
\text { Maxm Minimum }\end{array}$} \\
\hline & & 200 & 200 & 541 & 541 & 3.5 & 3.5 \\
\hline$\Delta^{52}$ & 3 & 270 & 46 & 596 & 179 & 6.4 & 4.4 \\
\hline$\triangle^{53}$ & 1 & 290 & 290 & 622 & 622 & 4.9 & 4.9 \\
\hline$\triangle^{54}$ & 5 & 200 & 80 & 564 & 189 & 7.9 & 5.3 \\
\hline$\triangle^{55}$ & 1 & 110 & 110 & 241 & 241 & 5.9 & 5.9 \\
\hline$\triangle^{56}$ & 3 & 990 & 260 & 1620 & 581 & 7.8 & 4.0 \\
\hline$\triangle^{57}$ & 1 & 340 & 340 & 979 & 979 & 7.7 & 7.7 \\
\hline$\triangle^{58}$ & 1 & 43 & 43 & 121 & 121 & 6.6 & 6.6 \\
\hline$\Delta^{59}$ & 4 & 250 & 19 & 415 & 56 & 7.0 & 6.5 \\
\hline$\triangle^{60}$ & 3 & 310 & 46 & 640 & 127 & 6.6 & 4.0 \\
\hline$\Delta^{61}$ & 2 & 430 & 23 & 858 & 73 & 6.8 & 4.0 \\
\hline$\Delta^{62}$ & 3 & 39 & 16 & 201 & 117 & 7.0 & 6.5 \\
\hline$\triangle^{63}$ & 2 & 280 & 30 & 646 & 156 & 6.8 & 6.6 \\
\hline$\triangle^{64}$ & 3 & 830 & 390 & 1800 & 966 & 7.7 & 7.3 \\
\hline$\triangle^{65}$ & 2 & 130 & 110 & 354 & 349 & 7.7 & 7.4 \\
\hline$\triangle^{66}$ & 2 & 8 & 2.9 & 43 & 24 & 6.8 & 6.4 \\
\hline$\triangle^{67}$ & 1 & 18 & 18 & 65 & 65 & 6.8 & 6.8 \\
\hline$\triangle^{68}$ & 1 & 40 & 40 & 164 & 164 & 7.7 & 7.7 \\
\hline$\triangle^{69}$ & 1 & 590 & 590 & 1400 & 1400 & 7.5 & 7.5 \\
\hline$\Delta^{70}$ & 3 & 850 & 26 & 1660 & 102 & 8.1 & 6.2 \\
\hline$\triangle^{71}$ & 4 & 310 & 160 & 1051 & 402 & 4.0 & 2.0 \\
\hline$\triangle^{72}$ & 2 & 72 & 65 & 254 & 234 & 7.0 & 6.7 \\
\hline
\end{tabular}

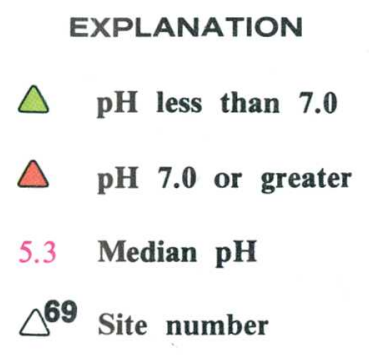




\author{
6.0 GROUND WATER \\ 6.1 Yields, Recharge, Water Levels and Movement
}

\title{
Yields to Wells Vary Widely
}

\author{
Pennsylvanian rocks generally have low yields to wells on the order of 50 gallons \\ per minute; alluvium yields to wells are as much as 700 gallons per minute.
}

Pennsylvanian rocks generally yield less than 50 gallons per minute to wells, although yields of as much as 100 gallons per minute have been reported. Most wells in Pennsylvanian rocks are 50 to 200 feet deep. The depth to an adequate water supply for domestic and livestock uses depends on the size, number, and degree of interconnection of fractures intercepted by a well (Cordova, 1963). Recharge to the Pennsylvanian rocks is mostly by infiltration of precipitation although flooding along streams occasionally may be a source of recharge. Recharge rates are not known but probably average less than an inch per year. Water levels in Pennsylvanian rocks fluctuated widely, as much as 10 feet per year (fig. 6.1-1), in response to rainfall and evapotranspiration. Water is mostly in fractures, and only a small change in the volume of water may cause water-level changes of several feet. Water levels generally are highest in the spring and lowest in late summer or fall. Groundwater movement in Pennsylvanian rocks generally follows the slope of the land surface and ground water divides generally coincide with surface water divides. Locally, ground-water-flow patterns have been modified by surface and underground mining for coal. Because of the low rate of flow, mining probably does not significantly affect regional flow of ground water.

The alluvium along the Arkansas River yields between 300 and 700 gallons per minute to wells. Excessive water-level declines caused by pumping have not been noted. Recharge to the alluvium along the Arkansas River averages about 10 inches per year (Bedinger and others, 1963). Water levels in alluvium fluctuate seasonally in response to precipitation, evapotranspiration, and changes in river stage. The magnitude of fluctuations in many areas along the Arkansas River has been reduced from 6 to 10 feet annually to less than 5 feet annually since the navigation system began controlling river stage. The responses of ground-water levels to river-stage changes decreases with distance from the river. Groundwater movement in the Arkansas River alluvium is toward the river and down valley. Modification of this pattern can be anticipated in areas of heavy pumping (Bedinger and others, 1963). 


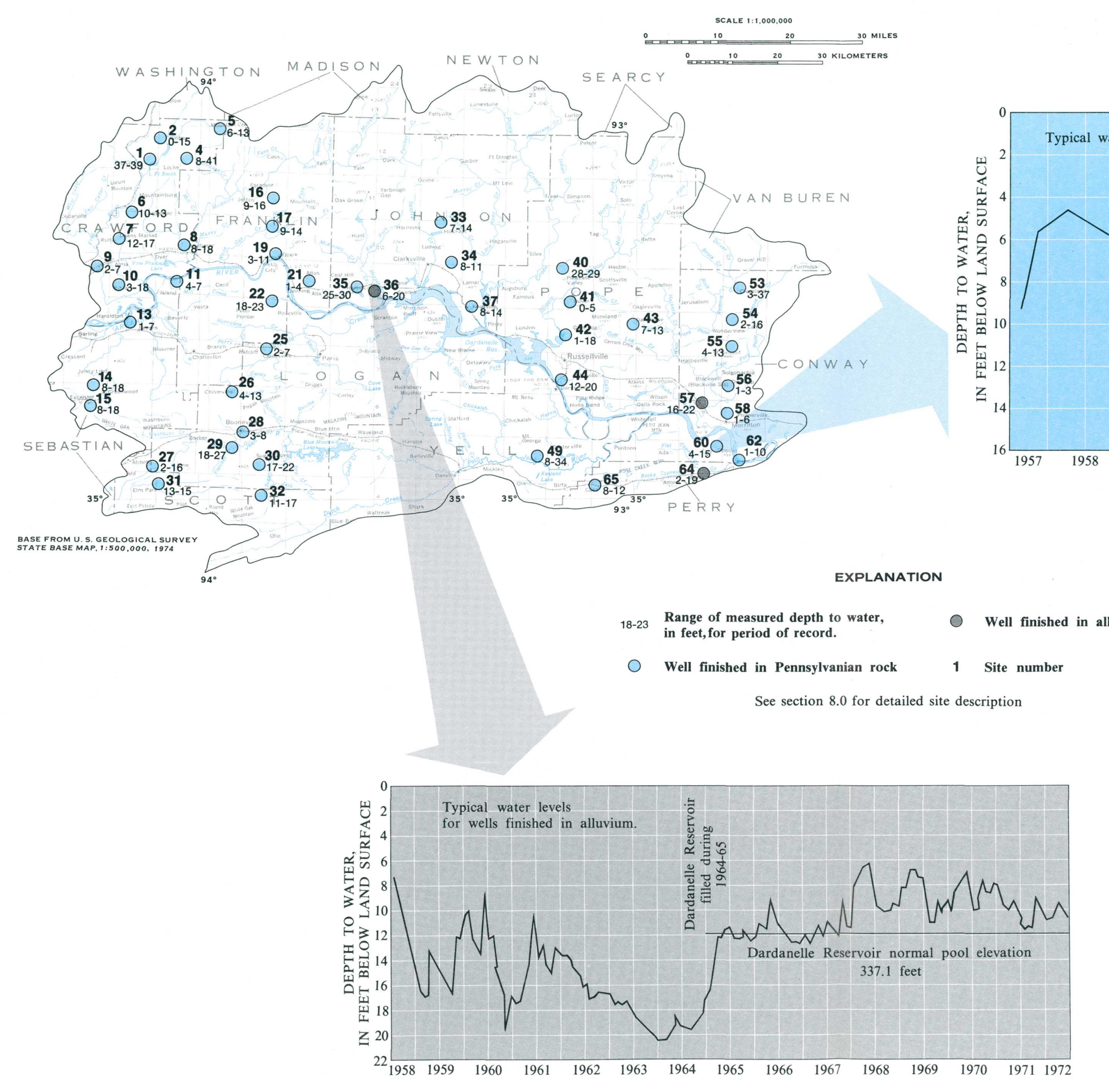

Figure 6.1-1 Locations of observation wells and associated water-level fluctuations. 


\title{
6.0 GROUND WATER--Continued \\ 6.2 Ground-Water Quality
}

\section{Chemical Quality of Ground Water is Highly Variable, but in Most Areas the Water is Suitable for Drinking}

\author{
Specific conductance of water from the Pennsylvanian rocks generally is lower \\ than in water from alluvium.
}

The quality of ground water is highly variable, but the water generally is suitable for most uses. Specific conductance of water from selected wells in Pennsylvanian rocks is given in figure 6.2-1.

Specific conductance of water from shallow wells in Pennsylvanian rocks averages 370 micromhos per centimeter at $25^{\circ}$ Celsius $(\mu \mathrm{mhos} / \mathrm{cm})$, and ranges from 59 to $1,200 \mu \mathrm{mhos} / \mathrm{cm}$ (fig. 6.2-1). Principal constituents of water from Pennsylvania rocks are sodium, bicarbonate, and chloride ions (fig. 6.2-2). Information from logs of gas tests and wells indicates that saltwater is generally present at depths of 1000 feet although the depth to saltwater may range from 500 to 2000 feet (Cordova, 1963). Seasonal variations in water quality have been reported for some wells, particularly during periods of drought or heavy pumping when odor and taste of the water may deteriorate as water levels drop.

Specific conductance of water from wells in the alluvium average $516 \mu \mathrm{mhos} / \mathrm{cm}$ and ranges from 101 to $2,920 \mu \mathrm{mhos} / \mathrm{cm}$. Principal constituents of water from the alluvium are mostly calcium, magnesium, and bicarbonate ions (fig. 6.2-2). High iron concentrations are common in alluvial water and often exceed drinking-water standards (U.S. Environmental Protection Agency, 1977). Most water samples from the alluvium were collected prior to construction of the navigation system; it is not known whether the system has altered water quality. 


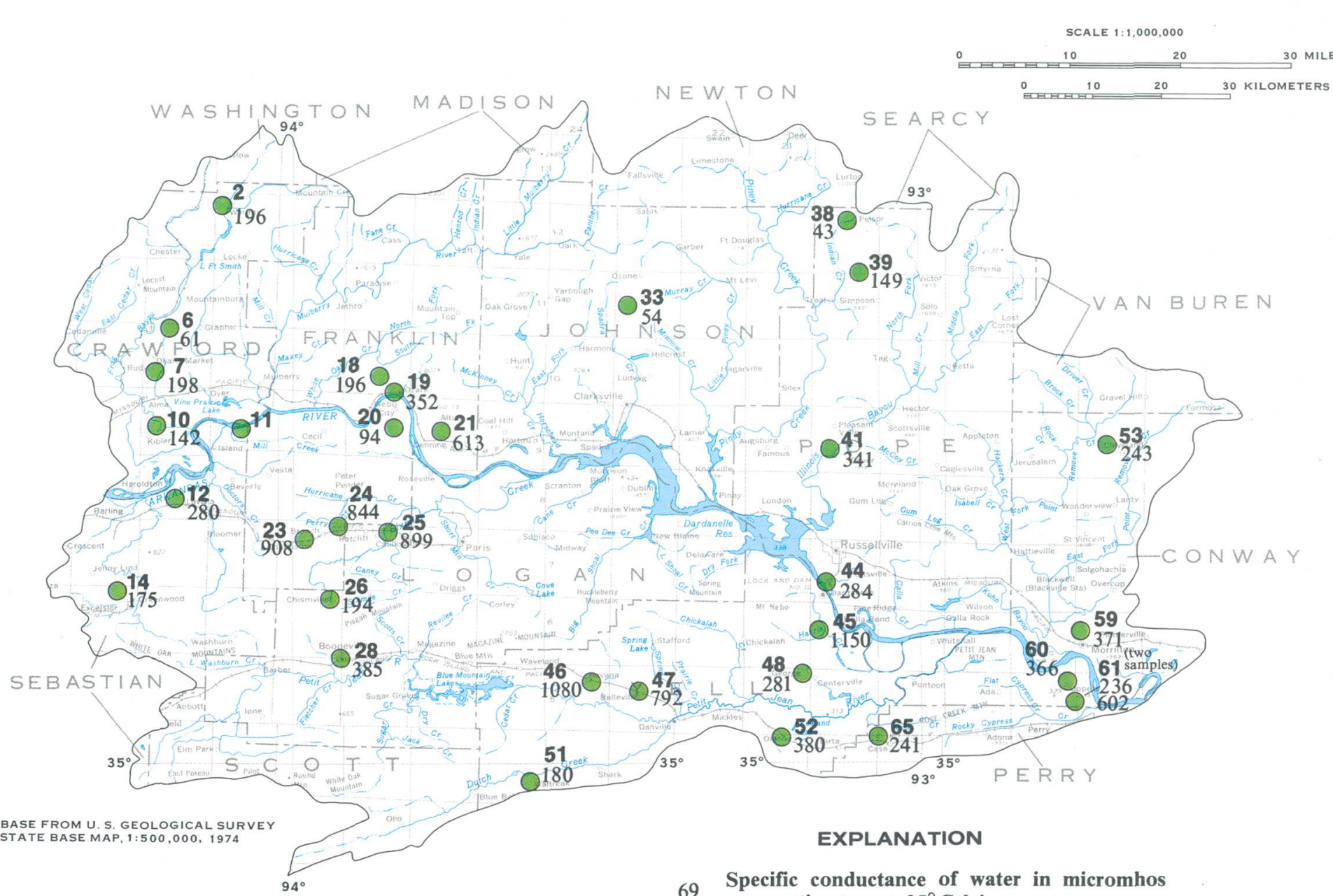

69 Specific conductance of water in micromhos

48 Site location and number

See section 8.0 for detailed site description

Figure 6.2-1 Locations of wells in Pennsylvanian rocks for which chemical analyses of water are available.
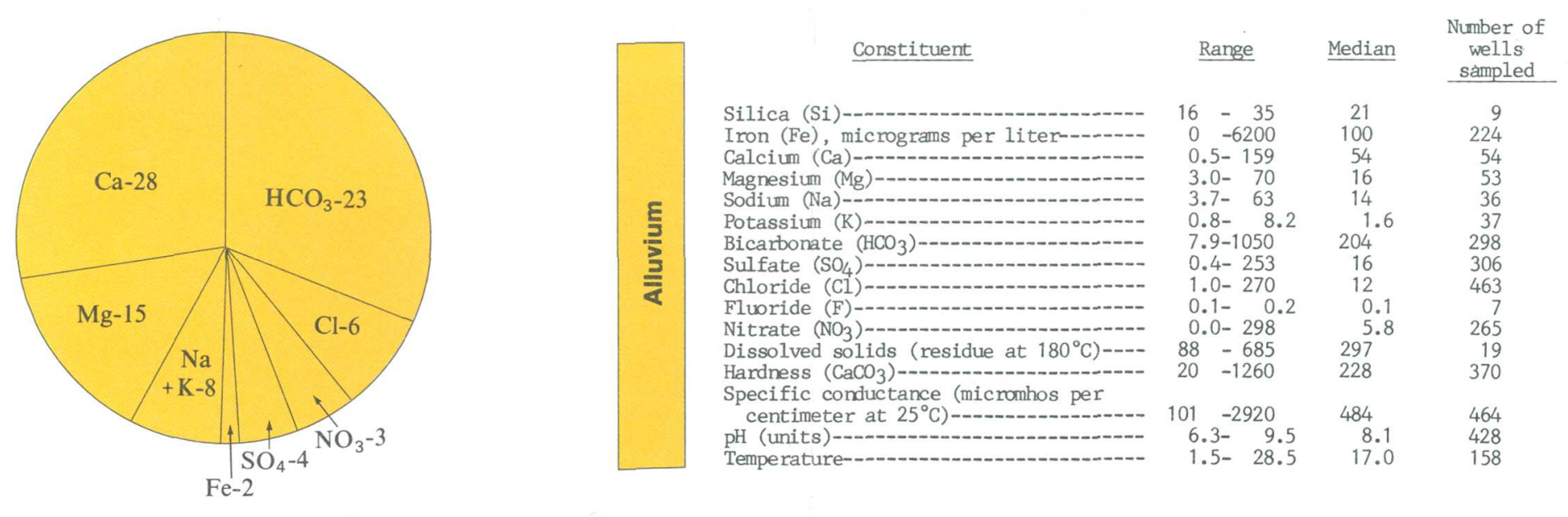

Percent of milliequivalents

(Concentrations in milligrams per 1iter unless otherwise specified)

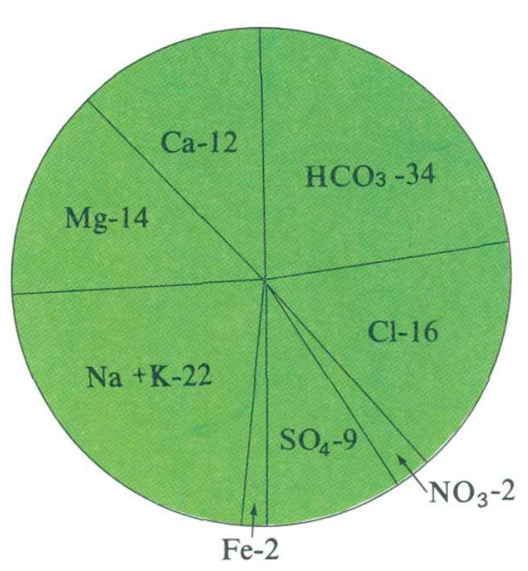

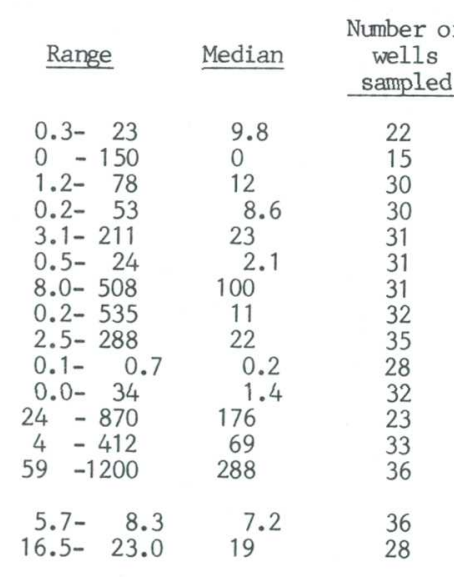

Figure 6.2-2 Range and average values for dissolved constituents in ground water and percentage of milliequivalents per liter. 


\subsection{WATER-DATA SOURCES \\ 7.1 Introduction}

\section{NAWDEX, WATSTORE, OWDC, and STORET have Water-Data Information}

\section{Water data are collected in coal areas by a large number of organizations in response to a wide variety of needs.}

Three activities within the U.S. Geological Survey help to identify and improve access to the vast amount of existing data.

(1) The National Water Data Exchange (NAWDEX) indexes the water data available from more than 400 organizations and serves as a central focal point to help those needing data to determine what information is available.

(2) The National Water Data Storage and Retrieval System (WATSTORE) serves as the central respository of water data collected by the U.S. Geological Survey and contains data on the quantity and quality of surface and ground water.

(3) The Office of Water Data Coordination (OWDC) coordinates Federal water-data acquisition activities and maintains a "Catalog of Information on Water Data." To assist in identifying available water-data activities in coal provinces of the United States, special indexes to the catalog are being printed and made available to the public.

In addition to U.S. Geological Survey water-data activities, the U.S. Environmental Protection Agency operates a data base called the Water Quality Control Information System (STORET). This data base is used for the storage and retrieval of data relating to the quality of waterways within and contiguous to the United States.

More detailed explanations of these four activities are given in sections 7.2, 7.3, 7.4, and 7.5. 


\title{
National Water-Data Exchange Simplifies Access to Water Data
}

\author{
The National Water-Data Exchange (NAWDEX) is a nationwide program, managed by \\ the U.S. Geological Survey, to assist users of water data or water-related \\ data in identifying, locating, and acquiring needed data.
}

NAWDEX is a national confederation of wateroriented organizations working together to make their data more accessible and to facilitate a more efficient exchange of water data.

Services are available through a Program Office at the U.S. Geological Survey's National Center in Reston, Va., and a nationwide network of Assistance Centers in 45 States and Puerto Rico, which provide local and convenient access to NAWDEX facilities (fig. 7.2-1). A directory is available upon request that provides names of organizations and persons to contact, addresses, telephone numbers, and office hours for each of these locations [Director of Assistance Centers of the National Water-Data Exchange (NAWDEX), U.S. Geological Survey Open-File Report 80-1193].

NAWDEX can assist any organization or individual in identifying and locating water data and referring the requester to the organization that retains the data required. To perform this service, NAWDEX maintains a computerized Master WaterData Index (fig. 7.2-2) that identifies sites for which water data are available, the type data available for each site, and the organization retaining the data. A Water-Data Sources Directory (fig. 7.2-3) also is maintained that identifies organizations and the locations within these organizations from which data may be obtained. In addition, NAWDEX has direct access to some large water-data bases of its members and has reciprocal agreements for the exchange of services with others.

Charges for NAWDEX services are assessed at the option of the organization providing the requested data or data service. Search-assistance services are provided free by NAWDEX to the greatest extent possible. Charges are assessed, however, for those requests requiring computer cost, extensive personnel time, duplicating services, or other costs encountered by NAWDEX in the course of providing services. Charges assessed by NAWDEX Assistance Centers will not exceed the direct costs incurred in responding to the data request. Estimates of cost are provided by NAWDEX upon request, however estimates will be automatically provided when costs are anticipated to be substantial.

For additional information concerning the NAWDEX program or its services contact:

Program Office

National Water Data Exchange (NAWDEX)

U.S. Geological Survey

421 National Center

12201 Sunrise Valley Drive

Reston, VA 22092

Telephone: (703) 860-6031

FTS 928-6031

Hours: $7: 45$ to $4: 15$ Eastern Standard Time

or

\section{NAWDEX ASSISTANCE CENTER} ARKANSAS

U.S. Geological Survey

Water Resources Division

2301 Federal Office Building

Little Rock, Arkansas 72201

Telephone: (501) 378-6391 FTS 740-6391

Hours: 7:30 to 4:00 Central Standard Time 
MASTER WATER DATA INDEX

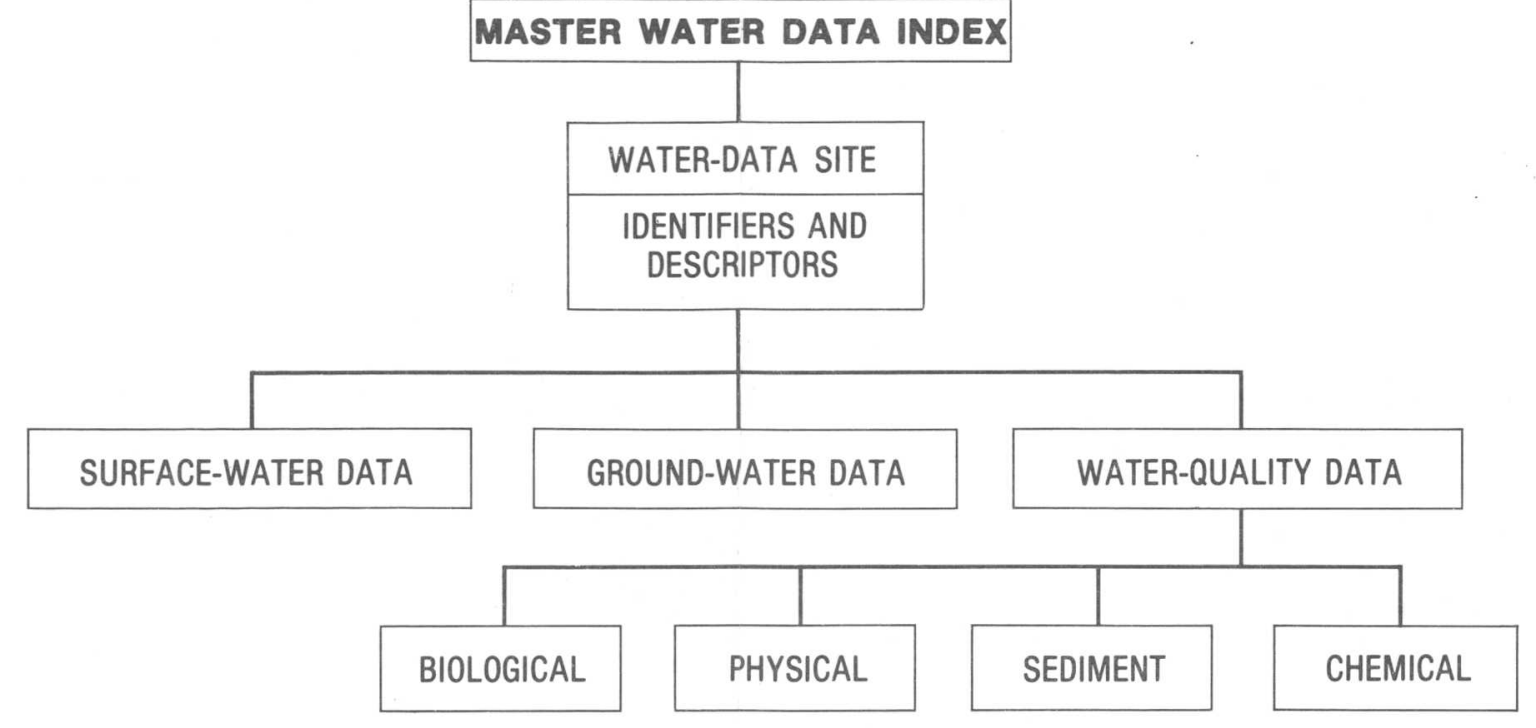

\section{A PROGRAM TO PROVIDE ACCESS}

TO WATER DATA

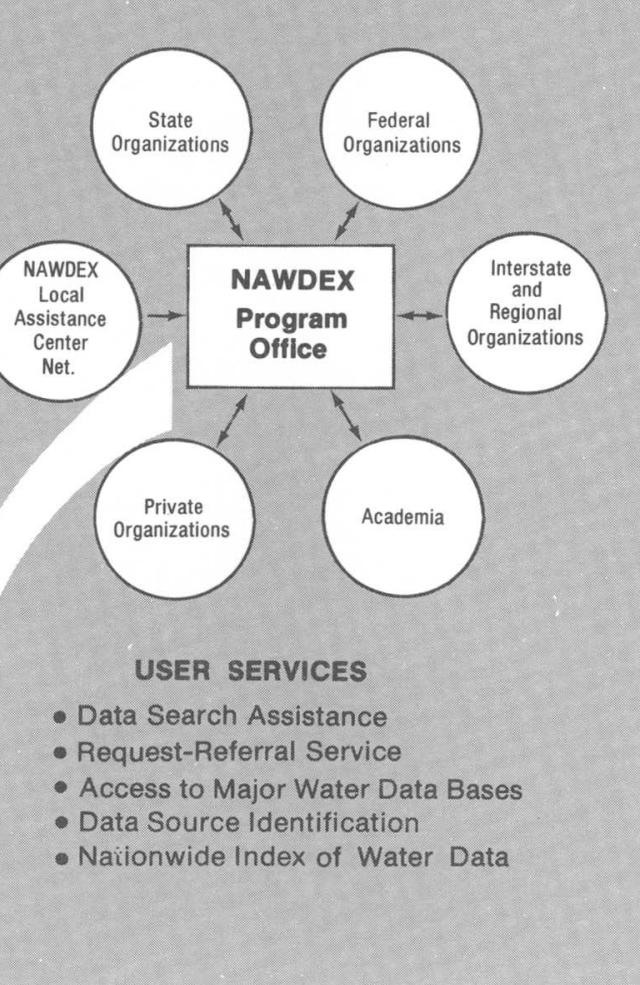

Figure 7.2-1 Access to water data
Figure 7.2-2 Master water-data index

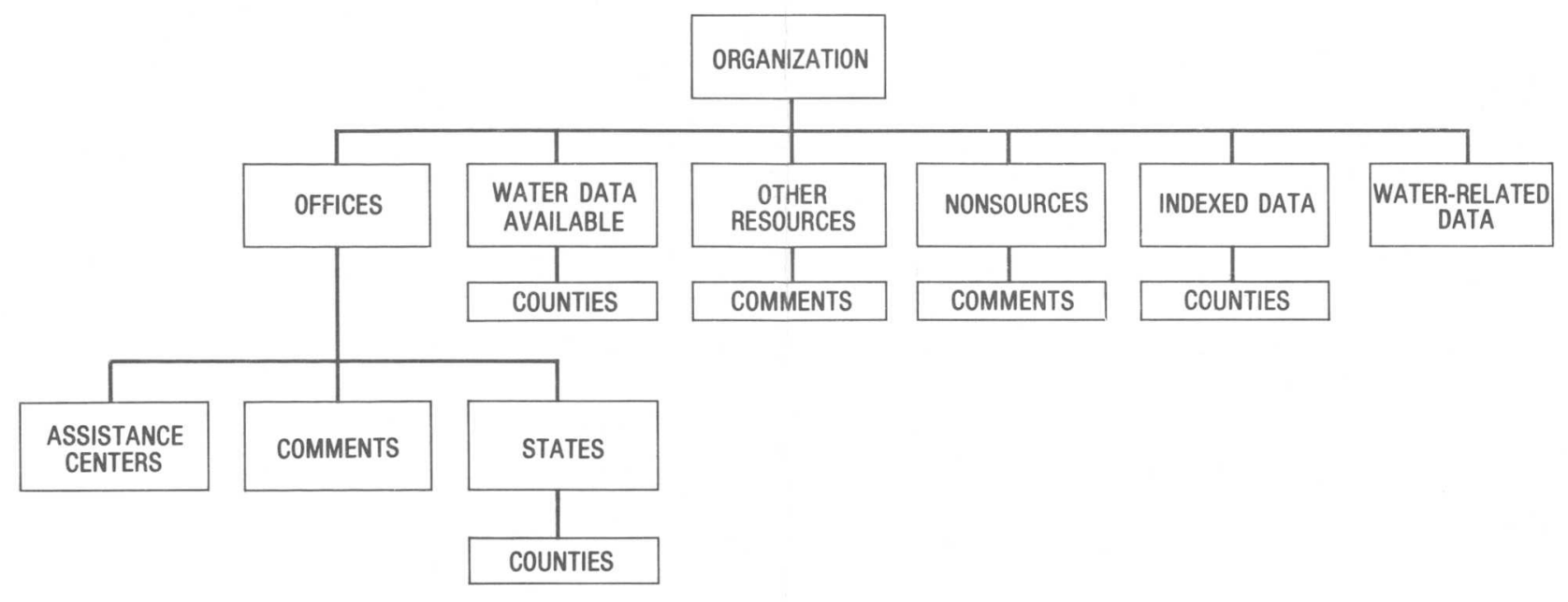

Figure 7.2-3 Water-data sources directory 


\subsection{WATER-DATA SOURCES--Continued \\ 7.3 National Water-Data Storage and Retrieval System (WATSTORE) \\ National Water-Data Storage and Retrieval System Provides Computerized Data Program}

\section{The National Water-Data Storage and Retrieval System (WATSTORE) of the U.S. Geological Survey provides computerized procedures and techniques for processing water data and provides effective and efficient management of data-releasing activities.}

The National Water-Data Storage and Retrieval System (WATSTORE) was established in November 1971 to computerize the U.S. Geological Survey's existing water-data system and to provide effective and efficient management of its data-releasing activities. The system is operated and maintained on the central computer facilities of the Survey at its $\mathrm{Na}$ tional Center in Reston, Va. Data may be obtained from WATSTORE through the Water Resources Division's 46 district offices. General inquiries about WATSTORE may be directed to:

Chief Hydrologist

U.S. Geological Survey

437 National Center

Reston, VA 22092

or

\section{District Chief \\ U.S. Geological Survey \\ Water Resources Division \\ 2301 Federal Office Building \\ Little Rock, Arkansas 72201}

The Geological Survey currently (1982) collects data at approximately 16,000 stream-gaging stations, 1,000 lakes and reservoirs, 5,200 surface-water quality stations, 1,020 sediment stations, 30,000 waterlevel-observation wells, and 12,500 ground-waterquality wells. Each year many water-data collection sites are added and others are discontinued; thus, large amounts of information, both current and historical, are amassed by the Survey's data-collection activities.

The WATSTORE system consists of several files in which data are grouped and stored by common characteristics and data-collection frequencies. The system also is designed to allow for the inclusion of additional data files as needed. Currently, files are maintained for the storage of: (1) surface-water, water-quality, and ground-water data measured daily or continuously; (2) annual peak values for streamflow stations; (3) chemical analyses for surface- and ground-water stations; (4) water parameters measured more frequently than daily; and (5) geologic and inventory data for ground-water stations. In addition, an index file of stations for which data are stored in the system is also maintained (fig. 7.3-1).

All data files of the WATSTORE system are maintained and managed on the central computer facilities of the Geological Survey at its National Center. However, data may be entered into or retrieved from WATSTORE at other locations that are part of a nationwide telecommunication network.

Water data are used in many ways by decisionmakers for the management, development, and monitoring of our water resources. In addition to its data processing, storage, and retrieval capabilities, WATSTORE can provide a variety of useful products ranging from simple data tables to complex statistical analyses. A minimum rate, plus the actual cost, is charged to the requester. 


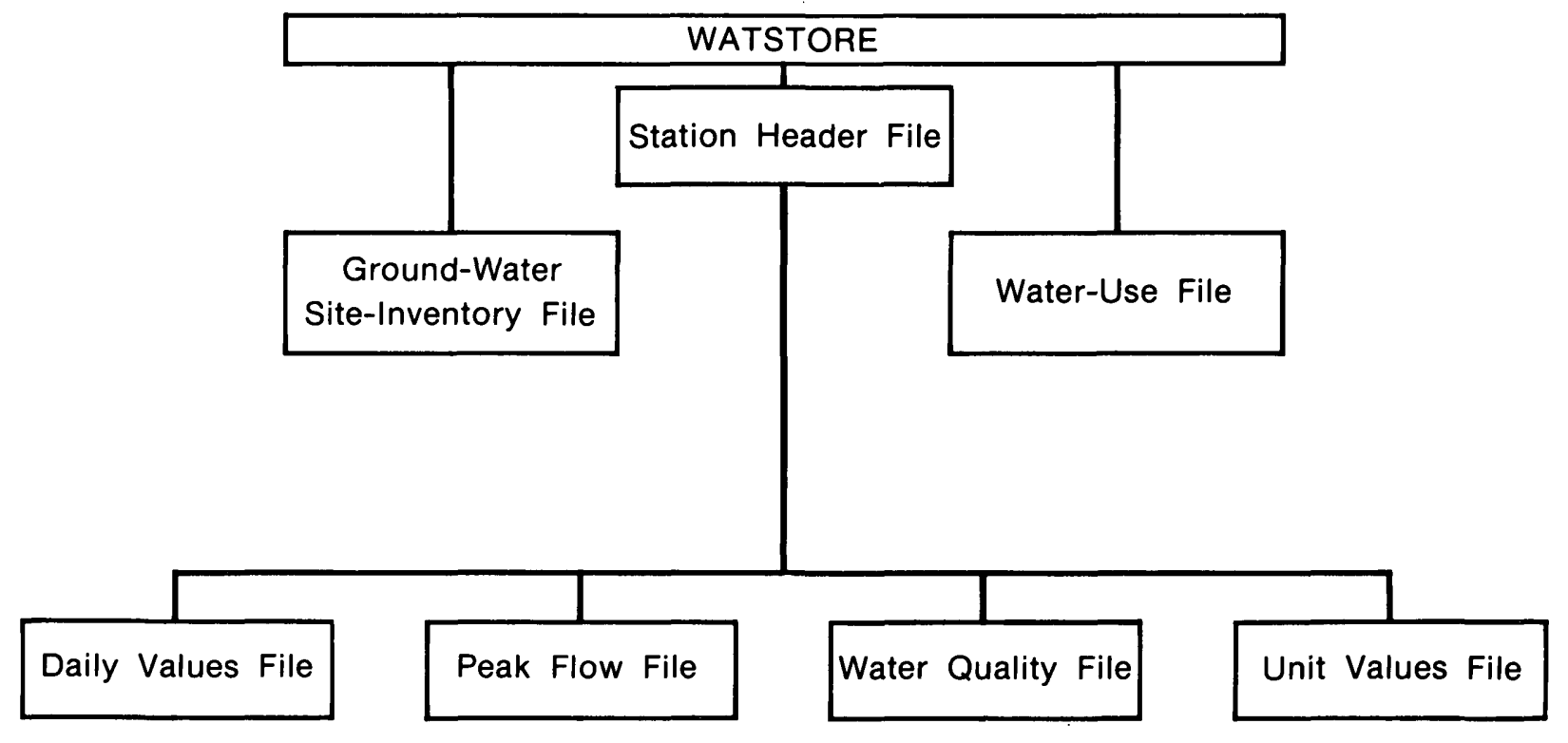

Figure 7.3-1 Index file stored data 


\author{
7.0 WATER-DATA SOURCES--Continued \\ 7.4 Index to Water-Data Activities in Coal Provinces
}

\title{
Water Data Indexed for Coal Provinces
}

\section{A special index "Index to Water-Data Activities in Coal Provinces of the United States" has been published by the U.S. Geological Survey's Office of Water Data Coordination (OWDC).}

The "Index to Water-Data Activities in Coal Provinces of the United States" was prepared to assist those involved in developing, managing, and regulating the Nation's coal resources by providing information on the availability of water-resources data in the major coal provinces of the United States. The index is derived from the "Catalog of Information on Water Data," which is a computerized information file about water-data acquisition activities in the United States and its territories and possessions, with some international activities included.

This special index consists of five volumes (fig. 7.4-1): volume I, Eastern Coal province; volume II, Interior Coal province; volume III, Northern Great Plains and Rocky Mountain Coal provinces; volume IV, Gulf Coast Coal province; and volume V, Pacific Coast and Alaska Coal provinces. The information presented will aid the user in obtaining data for evaluating the effects of coal mining on water resources and in developing plans for meeting additional water data needs. The report does not contain the actual data; rather, it provides information that will enable the user to determine if needed data are available.

Each volume of this special index consists of four parts: Part A, Streamflow and Stage Stations; Part B, Quality of Surface-Water Stations; Part C, Quality of Ground-Water Stations; and Part D, Areal Investigations and Miscellaneous Activities. Information given for each activity in Parts A-C includes: (1) the identification and location of the station, (2) the major types of data collected, (3) the frequency of data collection, (4) the form in which the data are stored, and (5) the agency or organization reporting the activity. Part D summarizes hydrologic investigations and water-data activities not included in other parts of the index. The agencies that submitted the information, agency codes, and the number of activities reported by type are included.

Those who need additional information from the Catalog File or who need assistance in obtaining water data should contact the National Water Data Exchange (NAWDEX). (See section 7.2.) 


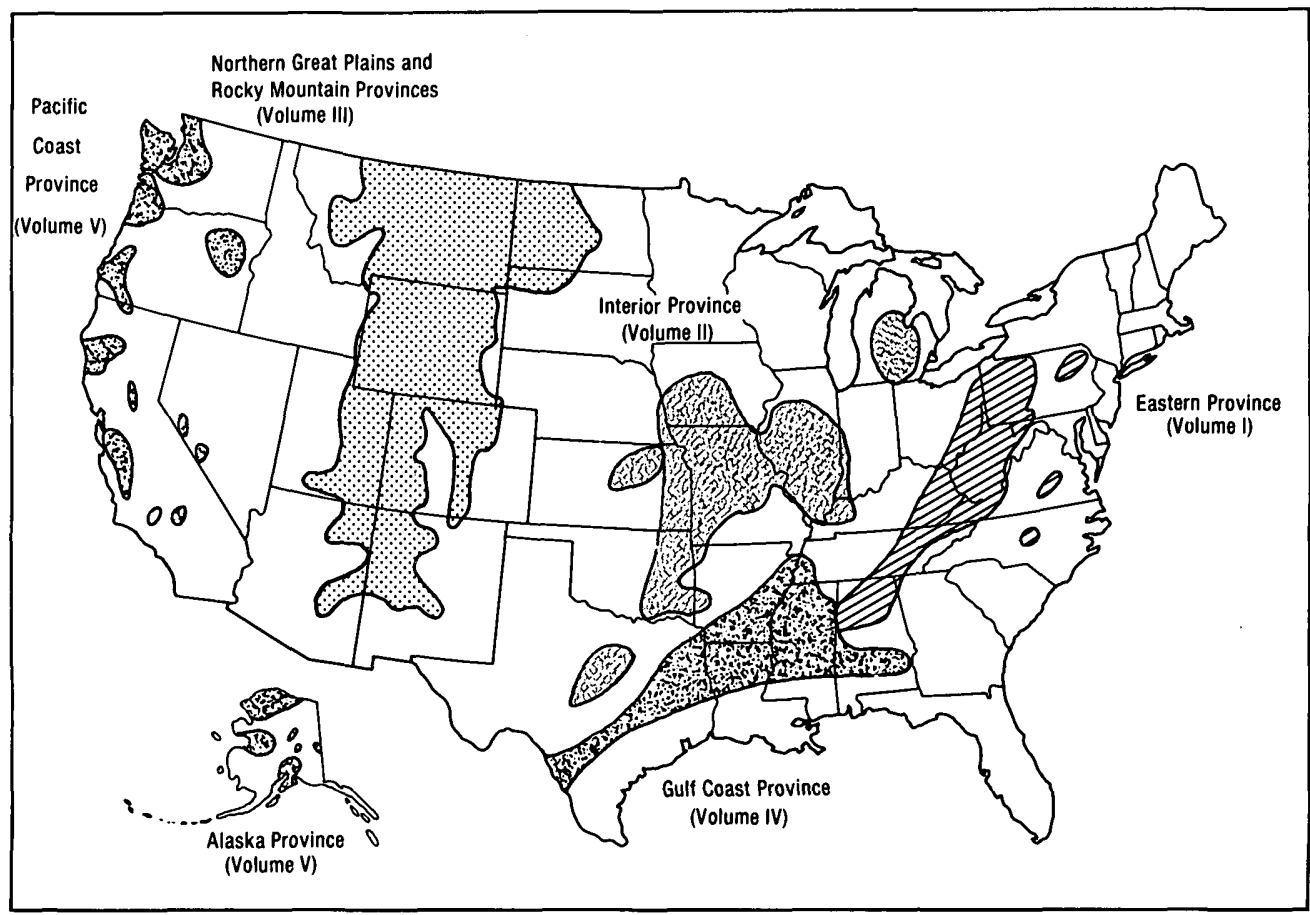

Figure 7.4-1 Index volumes and related provinces 


\subsection{WATER-DATA SOURCES--Continued 7.5 STORET}

\section{STORET is U.S. Environmental Protection Agency's Computerized Data-Base System}

\section{STORET is the computerized water-quality data-base system maintained by the U.S. Environmental Protection Agency.}

STORET is a computerized data-base system maintained by the U.S. Environmental Protection Agency (1979) for the storage and retrieval of data relating to the quality of the waterways within and contiguous to the United States. The system is used to store data on water quality, water-quality standards, point sources of pollution, pollution-caused fishkills, waste-abatement needs, implementation schedules, and other water-quality related information. The Water-Quality File (WQF) is the most widely used STORET file.

The data in the WQF are collected through cooperative programs involving EPA, State waterpollution-control authorities, and other governmental agencies. The U.S. Geological Survey, the U.S. Forest Service, the U.S. Army Corps of Engineers, the Bureau of Reclamation, and the Tennessee Valley Authority all use STORET's WQF to store and retrieve data collected through their water-quality monitoring programs.
There are 1,800 water-quality parameters defined within STORET's WQF. In 1976 there were data from more than 200,000 unique collection points in the system. Figure 7.5-1 illustrates the groups of parameters and the number of observations that are in the WQF.

State, Federal, interstate, and local government agencies can become STORET users. Information on becoming a user of the system can be obtained by contacting the Environmental Protection Agency. The point of contact for Region VI is:

Director

Surveillance and Analysis Division Environmental Protection Agency 1201 Elm Street Dallas, Texas 75270 


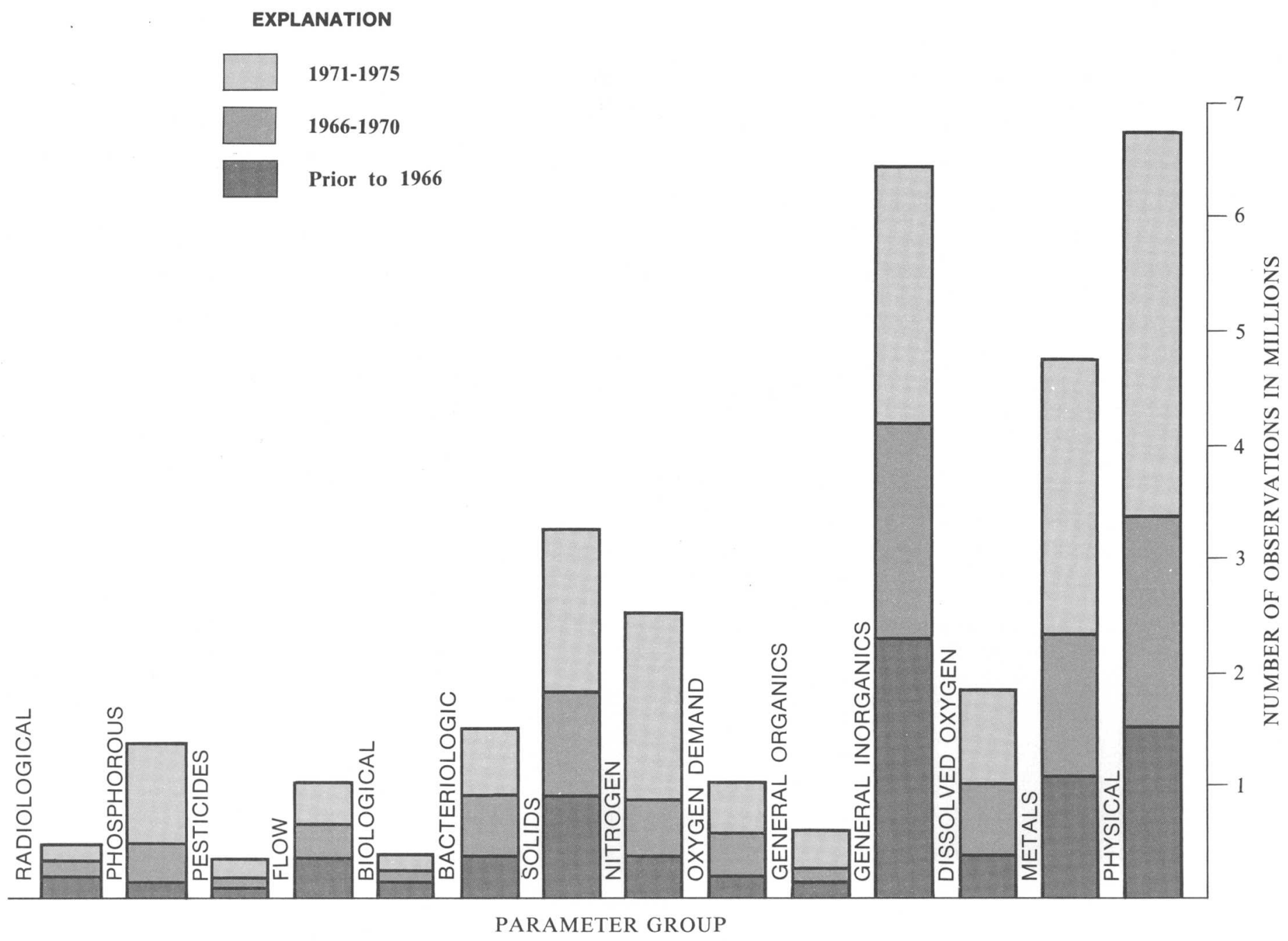

Figure 7.5-1 Parameter groups and number of observations in the Water Quality File. 


\subsection{GROUND-WATER SITES}

\begin{tabular}{|c|c|c|c|c|c|c|}
\hline $\begin{array}{c}\text { Site } \\
\text { No. }\end{array}$ & $\begin{array}{c}\text { Site } \\
\text { Identification } \\
\text { No. } \\
\end{array}$ & County & $\begin{array}{c}\text { Local } \\
\text { No. }\end{array}$ & Aquifer & $\begin{array}{l}\text { Period of } \\
\text { water-level } \\
\text { record }\end{array}$ & $\begin{array}{l}\text { Date of } \\
\text { chemical } \\
\text { analysis }\end{array}$ \\
\hline 1 & 354054094090102 & Crawford & 12N30W26DCA2 & Atoka Formation & $1949-53$ & \\
\hline 2 & 354411094055201 & Crawford & 12N29WO 5DCC1 & Bloyd Shale & & $08-25-49$ \\
\hline 3 & 354320094063201 & Crawford & 12N29W07DDD1 & Atoka Formation & $1949-53$ & \\
\hline 4 & 354124094033901 & Crawford & 12N29W27ABA1 & Atoka Formation & $1949-51$ & \\
\hline 5 & 354445093584201 & Crawfond & 12N28W04BAA1 & Atoka Formation & $1949-50$ & \\
\hline 6 & 353536094121701 & Crawford & 10N30W04BAB1 & Atoka Formation & $1960-62$ & $09-13-60$ \\
\hline 7 & 353157094122301 & Crawford & 10N30W20CBB1 & Atoka Formation & $1960-61$ & $09-21-60$ \\
\hline 8 & 353036094032201 & Crawford & 10N29W27DAA1 & McAlester Shale & $1960-63$ & \\
\hline 9 & 352749094161901 & Crawfond & 09N31W1 5ABA1 & McAlester Shale & $1960-61$ & \\
\hline 10 & 352554094122901 & Crawford & 09N30W29BBC1 & McAlester Shale & $1960-61$ & $09-13-60$ \\
\hline 11 & 352628094043301 & Sebastian & 09N29W28AAA1 & Hartshorne Sandstone & $1957-66$ & $04-14-59$ \\
\hline 12 & 352119094103801 & Sebastian & 08N30W22CAD1 & McAlester Shale & & $04-14-59$ \\
\hline 13 & 352055094113901 & Sebastian & $08 \mathrm{~N} 30 \mathrm{~W} 28 \mathrm{ABC1}$ & McAlester Shale & $1957-66$ & \\
\hline 14 & 351331094161901 & Sebastian & 06N31W02CDC1 & Atoka Formation & $1960-61$ & $09-13-60$ \\
\hline 15 & 351101094163801 & Sebastian & 06N31W23BDC1 & Atoka Fomation & $1960-61$ & \\
\hline 16 & 353657093492601. & Franklin & $11 \mathrm{~N} 27 \mathrm{~W} 22 \mathrm{AAC} 1$ & Atoka Formation & $1960-61$ & \\
\hline 17 & 353259093500101 & Franklin & 10N27W1 OCBA1 & Atoka Formation & $1960-61$ & \\
\hline 18 & 352955093492101 & Franklin & 10N27W27AAA2 & Atoka Formation & & $09-14=60$ \\
\hline 19 & 352953093485801 & Franklin & 10N27W3 5BBA2 & Atoka Formation & $1960-63$ & $09-22-60$ \\
\hline 20 & 352652093493801 & Franklin & 09N27W23BDA1 & Atoka Formation & & $09-14-60$ \\
\hline 21 & 352534093454401 & Frarklin & 09N26W1 5CBA1 & Atoka Fo mation & $1960-61$ & $07-19-60$ \\
\hline 22 & 352302093501001 & Franklin & 08N27W02BBC1 & Hartshorne Sandstone & $1960-61$ & \\
\hline 23 & 352225093511301 & Franklin & 08N27W1 ODCC1 & Hartshorne Sandstone & & $11-30-65$ \\
\hline 24 & 351817093554001 & Logan & 07N27W04DDB1 & Savanna Sandstone & & $07-05-60$ \\
\hline 25 & 351817093544301 & Logan & $07 \mathrm{~N} 27 \mathrm{~W} 03 \mathrm{CCCl}$ & Savanna Sandstone & $1960-61$ & $07-05-60$ \\
\hline 26 & 351307093551201 & Logan & 06N28W02DAA1 & Atoka Formation & $1960-61$ & $09-14-60$ \\
\hline 27 & 350135094071201 & Logan & 05N29W31DCA1 & Atoka Fomation & $1960-61$ & \\
\hline 28 & 350733093534601 & Logan & 05N27W06BCB1 & Atoka Fomation & $1960-61$ & $09-22-60$ \\
\hline 29 & 350558093581201 & Logan & $05 \mathrm{~N} 27 \mathrm{Wl}$ 3CBA1 & Atoka Formation & $1960-61$ & \\
\hline 30 & 350358093512201 & Logan & $0 \mathrm{NN} 27 \mathrm{~W} 33 \mathrm{ABA} 2$ & Atoka Formation & $1960-63$ & \\
\hline 31 & 350140094071201 & Scott & 04N29W07CAD1 & Hartshorne Sandstone & $1960-61$ & \\
\hline 32 & 350102093513301 & Scott & 04N27W04DACl & Hartshorne Sandstone & $1960-61$ & \\
\hline 33 & 353318093245801 & Johnson & $10 \mathrm{~N} 23 W 03 \mathrm{BAC1}$ & Hartshorne Sandstone & $1960-61$ & $04-13-59$ \\
\hline
\end{tabular}




\begin{tabular}{|c|c|c|c|c|c|c|}
\hline $\begin{array}{c}\text { Site } \\
\text { No. }\end{array}$ & $\begin{array}{c}\text { Site } \\
\text { Identification } \\
\text { No. } \\
\end{array}$ & County & $\begin{array}{c}\text { Local } \\
\text { No. }\end{array}$ & Aqui fer & $\begin{array}{c}\text { Period of } \\
\text { water-level } \\
\text { recond }\end{array}$ & $\begin{array}{l}\text { Date of } \\
\text { chemical } \\
\text { analysis }\end{array}$ \\
\hline 34 & 353040093244001 & Johnson & 10N23W34DBD1 & McAlester Shale & $1960-61$ & \\
\hline 35 & 352530093365801 & Johnson & 09N2 5W23BBD1 & Hartshorne Sandstone & $1960-61$ & \\
\hline 36 & 352504093360001 & Johnson & 09N24W19CCD1 & Quaternary Alluvium & $1958-72$ & \\
\hline 37 & 352322093210701 & Johnson & 09N22W32CCC1 & McAlester Shale & $1960-63$ & \\
\hline 38 & 354233093060201 & Pope & $12 \mathrm{~N} 20 \mathrm{~W} 1 \mathrm{OABC} 1$ & Atoka Formation & & $09-07-60$ \\
\hline 39 & 353904093060301 & Pope & 12N20W34ACD1 & Atoka Formation & & $09-07-60$ \\
\hline 40 & 352758093072401 & Pope & 09N20W0 5AAA1 & Atoka Formation & $1960-61$ & \\
\hline 41 & 35241,4093063201 & Pope & 09N2OW27CBB1 & Atoka Formation & $1960-61$ & $09-07-60$ \\
\hline 42 & 351943093074401 & Pope & 08N2OW21CAA1 & Atoka Formation & $1960-63$ & \\
\hline 43 & 352117092573501 & Pope & 08N19W1 2DAA1 & Atoka Formation & $1960-63$ & \\
\hline 44 & 351428093081001 & Pope & $07 \mathrm{~N} 20 \mathrm{~W} 20 \mathrm{CDA} 1$ & McAlester Shale & & $09-07-60$ \\
\hline 45 & 351051093092901 & Yell & 06N20W1 8AAB1 & Atoka Formation & & $09-27-60$ \\
\hline 46 & 350631093320801 & Yell & 0 SN24W1 QACD1 & Atoka Fo mation & & $07-01-76$ \\
\hline 47 & 350534093265901 & Yell & 0 N23W16ACA1 & Atoka Fọmation & & $07-01-76$ \\
\hline 48 & 350641093110001 & Yell & 0S21W01CDA1 & Atoka Fomation & & $03-03-61$ \\
\hline 49 & 350418093120001 & Yell & 0NN21W23DBA1 & Atoka Formation & $1960-68$ & \\
\hline 51 & 345852093372101 & Yell & 04N2 SW23DAC1 & Atoka Formation & & $10-25-62$ \\
\hline 52 & 350155093130701 & Yell & 04N21W03ADA1 & Atoka Fo mation & & $07-05-63$ \\
\hline 53 & 352510092424201 & Conway & 09N16W16CCC1 & Atoka Formation & $1960-61$ & $09-25-60$ \\
\hline 54 & 352308092434601 & Corway & 08N1 6W08BCC1 & Atoka Formation & $1960-63$ & \\
\hline 55 & 351803092435201 & Conway & 08N16W32BBB1 & Atoka Formation & $1960-61$ & \\
\hline 56 & 351333092440601 & Conway & 07N16W30AAD1 & Atoka Fo rmation & $1960-61$ & \\
\hline 57 & 351113092483501 & Conway & 06N17W04DDC1 & Quaternary Alluvium & $1930-72$ & \\
\hline 58 & 351026092443801 & Conway & 06N16W07DCB1 & Atoka Formation & $1960-63$ & \\
\hline 59 & 351026092443802 & Corway & 06N16W07DCB2 & Atoka Formation & & $09-15-60$ \\
\hline 60 & 350604092460201 & Corway & 0 SN1 TW01CCC1 & Hartshorne Sandstone & $1957-66$ & $01-13-59$ \\
\hline 61 & 350509092450201 & Corway & 05N17W1 3AAA1 & Pennsylvanian System & & $\begin{array}{l}01-25-59 \\
08-25-59\end{array}$ \\
\hline 62 & 350510092434901 & Conway & $05 \mathrm{~N} 16 \mathrm{~W} 17 \mathrm{BBB} 1$ & Atoka Formation & $1959-60$ & \\
\hline 64 & 350405092450401 & Perry & $05 N 17 W 24 A A D 1$ & Quaternary Alluvium & $1957-66$ & \\
\hline 65 & 350127093033301 & Perry & 04N19W06DBA1 & Atoka Formation & $1962-63$ & $08-10-62$ \\
\hline
\end{tabular}




\subsection{SELECTED REFERENCES}

Bedinger, M. S., Emmett, L. F., and Jeffery, H. G., 1963, Ground-water potential of the alluvium of the Arkansas River between Little Rock and Fort Smith, Arkansas: U.S. Geological Survey Water-Supply Paper 1669-L, 29 p.

Bush, W. V., and Gilbreath, L. B., 1978, Inventory of surface and underground coal mines in the Arkansas Valley coal field: Little Rock, Arkansas Geological Commission Information Circular $20-\mathrm{L}, 15 \mathrm{p}$.

Cordova, R. M., 1963, Reconnaissance of the ground-water resources of the Arkansas Valley region Arkansas: U.S. Geological Survey Water-Supply Paper 1669-BB, 33 p.

Fenneman, N. M., 1938, Physiography of eastern United States: New York, McGraw-Hill, 724 p.

Haley, B. R., 1960, Coal Resources of Arkansas, 1954: U.S. Geological Survey Bulletin 1072-P, p. 796-831.

---1977, Low-volatile bituminous coal and semianthracite in the Arkansas valley coal field, Arkansas Geological Commission Information Circular, 20-K, $26 \mathrm{p}$.

Haley, B. R., and others, 1976, Geologic map of Arkansas: U.S. Geological Survey.

Haley, B. R., and others, 1979, The Mississippian and Pennsylvanian Systems in the United States-Arkansas: U.S. Geological Survey Professional Paper 1110-0, 14 p.

Hem, John D., 1970, Study and interpretation of the chemical characteristics of natural water: $2 \mathrm{~d}$ ed. U.S. Geological Survey Water Supply 1473, 363 p.

Hines, M. S., 1975, Flow duration and low-flow frequency determinations of Arkansas streams: Little Rock, Arkansas Geological Commission Water Resources Circular No. 12, 75 p.

National Water Data Exchange, 1980, Directory of Assistance Centers of the National Water Data Exchange (NAWDEX): U.S. Geological Survey Open-File Report 80-1193, 10 p.
Patterson, J. L., 1971, Floods in Arkansas, magnitude and frequency characteristics through 1968: Little Rock, Arkansas, Arkansas Geological Commission Water Resources Circular No. 11, $199 \mathrm{p}$.

Patterson, J. L., 1967, Storage requirements for Arkansas streams: Little Rock, Arkansas Geological Commission Water Resources Circular No. 10,35 p.

Skougstad and others, 1979, Methods for determination of inorganic substances in water and fluvial sediments: U.S. Geological Survey Techniques of Water-Resources Investigations, Book 5, Chapter A1, 626 p.

Sullavan, J. N., and Terry, J. E., 1970, Drainage areas of streams in Arkansas, Arkansas River basin: U.S. Geological Survey open-file report, $75 \mathrm{p}$.

U.S. Bureau of Mines, 1974, Demonstrated coal reserve base of the United States on January, 1974: Mineral Industry Surveys, 6 p.

U.S. Department of Agriculture, 1967, Soil association map, State of Arkansas: U.S. Soil Conservation Service, Little Rock, Arkansas.

U.S. Department of Commerce, 1975, Climatography of the United States, No. 20, Climate of Subiaco, Arkansas: National Oceanic and Atmospheric Administration, $4 \mathrm{p}$.

U.S. Environmental Protection Agency, 1979, Handbook Water Quality Control Information System (STORET): Office of Water and Hazardous Materials, Washington, D.C., 1,084 p.

---1977a, National interim primary drinking water: U.S. Environmental Protection Agency Report 57019-76-003, $159 \mathrm{p}$.

---1977b, Quality criteria for water: Washington, D.C., U.S. Environmental Protection Agency.

U.S. Geological Survey, issued annually, Water resources data for Arkansas: U.S. Geological Survey water-data reports, Little Rock. 